University of Louisville

ThinkIR: The University of Louisville's Institutional Repository

Electronic Theses and Dissertations

$5-2014$

\title{
Girls with guns : the disarmament and demobilization of female ex-combatants in Africa.
}

Emily Katherine Maiden

University of Louisville

Follow this and additional works at: https://ir.library.louisville.edu/etd

Part of the Political Science Commons

\section{Recommended Citation}

Maiden, Emily Katherine, "Girls with guns : the disarmament and demobilization of female ex-combatants in Africa." (2014). Electronic Theses and Dissertations. Paper 890.

https://doi.org/10.18297/etd/890

This Master's Thesis is brought to you for free and open access by ThinkIR: The University of Louisville's Institutional Repository. It has been accepted for inclusion in Electronic Theses and Dissertations by an authorized administrator of ThinkIR: The University of Louisville's Institutional Repository. This title appears here courtesy of the author, who has retained all other copyrights. For more information, please contact thinkir@louisville.edu. 


\title{
GIRLS WITH GUNS: THE DISARMAMENT AND \\ DEMOBILIZATION OF FEMALE EX-COMBATANTS IN AFRICA
}

\author{
By \\ Emily Katherine Maiden \\ B.A., University of Louisville, 2011

\begin{abstract}
A Thesis
Submitted to the Faculty of the

College of Arts and Sciences of the University of Louisville in Partial Fulfillment of the Requirements for the Degree of
\end{abstract}

Master of Arts

Department of Political Science

University of Louisville

Louisville, Kentucky

May 2014 

GIRLS WITH GUNS: THE DISARMAMENT AND

DEMOBILIZATION OF FEMALE EX-COMBATANTS IN AFRICA

By

Emily Katherine Maiden

B.A., University of Louisville, 2011

A Thesis Approved on

April 9, 2014

by the following Thesis Committee:

Jason Gainous, Ph.D., Committee Chair

Tricia Gray, Ph.D.

Nancy Nyquist Potter, Ph.D. 


\section{DEDICATION}

This thesis is dedicated to my parents

Michael and Julie Rath

and to my husband

Jordan Maiden

who support me in all my endeavors. 


\section{ACKNOWLEDGEMENTS}

I would first like to offer heartfelt thanks to the members of my Thesis Committee: Dr. Jason Gainous, Dr. Tricia Gray, and Dr. Nancy Nyquist Potter for their support and guidance through this process. I would also like to acknowledge the other professors who have been pivotal in the shaping of my academic and professional career including Drs. Patricia Condon, Jennie Burnet, Julie Bunck, and Thomas Maloney. Aside from mentorship and support, all of these faculty members have served as exemplary role models for me, daily demonstrating what it takes to be an effective scholar and teacher. Finally, I wish to acknowledge the mentorship of Dr. Michael Fowler, who has guided me through the turbulent waters of international law, diplomacy, U.S. foreign policy, mediation, and negotiation since 2008 . 


\title{
ABSTRACT \\ GIRLS WITH GUNS: THE DISARMAMENT AND \\ DEMOBILIZATION OF FEMALE EX-COMBATANTS IN AFRICA
}

\author{
Emily K. Maiden
}

April 9, 2014

Since the passing of U.N. Security Council Resolution 1325, states recovering from violence have worked to integrate females into peacemaking and peacebuilding processes. However, many states — particularly in Africa — struggle to craft policy that properly integrates female ex-combatants into disarmament, demobilization and reintegration (DDR) programs. Much of the literature on this subject focuses on how women and girls are reintegrated and rehabilitated into civilian society. However, the first vital steps in the DDR process are disarmament and demobilization. Utilizing the Peace Accords Matrix, I analyze a number of recent cases in Africa to examine ways in which DDR policy can be improved to provide females with better, safer access to the cantonment sites where the DDR process initiates. The most important changes that must take place include expanding the definition of "combatant" to include those who are not armed and removing the label of "dependent" from female ex-combatants. 
TABLE OF CONTENTS

PAGE

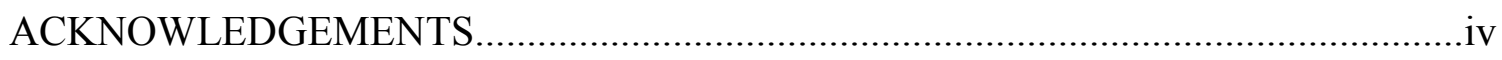

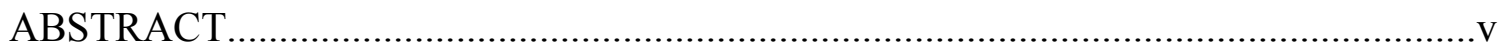

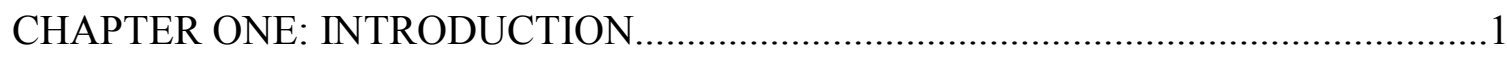

Women in Violence and Conflict...............................................................6

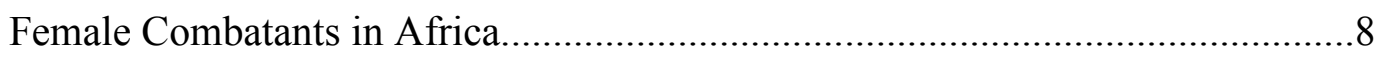

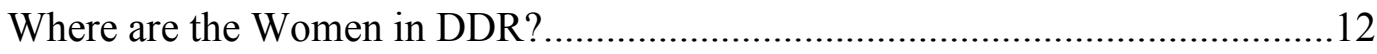

Why should We Care about Female Combatants?...............................................16

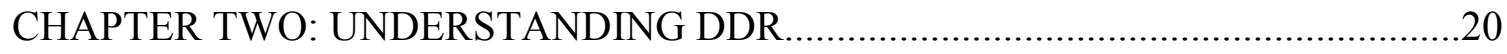

What is Disarmament, Demobilization, and Reintegration (DDR).......................20

Disarmament

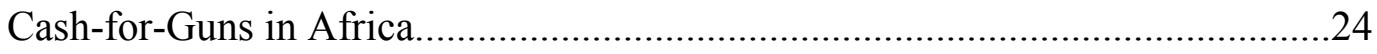

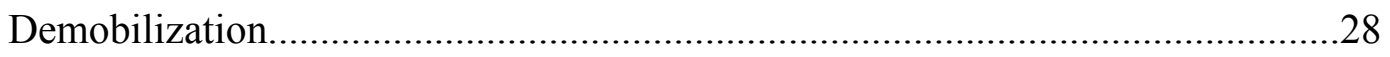

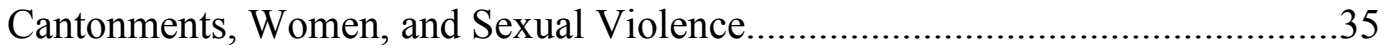

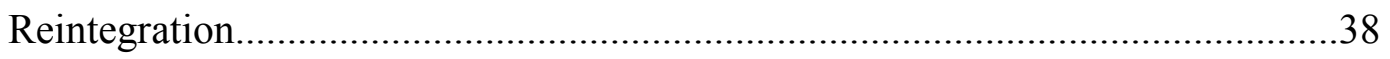

Reintegrating Child Soldiers........................................................................42

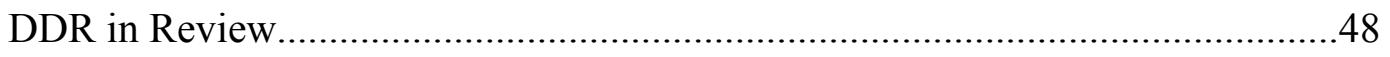


CHAPTER THREE: LITERATURE REVIEW AND METHODOLOGY.....

Start at the Source: Where does DDR Begin? .......................................................52

Effectiveness, Efficiency, and Equity in DDR Processes.......................................54

Research Design and Methodology.....................................................................57

The Peace Accords Matrix: Selecting the Case Studies..........................................58

Hypotheses: Fixing a Broken System...............................................................63

CHAPTER FOUR: DDR IN FOUR AFRICAN CASE STUDIES....................................65

Sierra Leone: One Person, One Gun.................................................................66

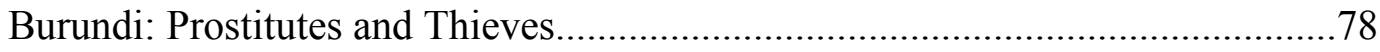

Liberia: Dangerous Disconnect.....................................................................90

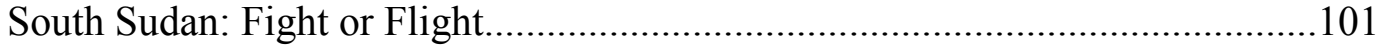

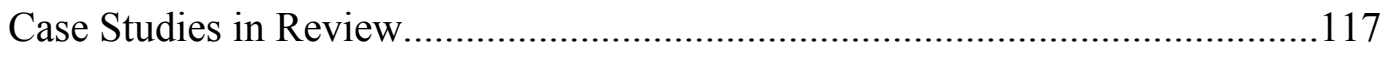

CHAPTER FIVE: POLICY RECOMMENDATIONS.................................................120

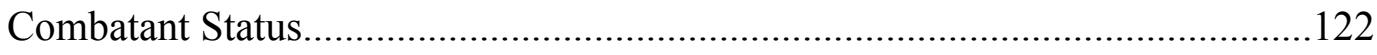

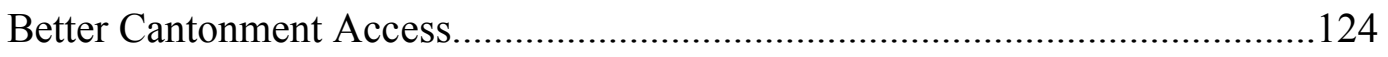

Increased Cantonment Security.....................................................................125

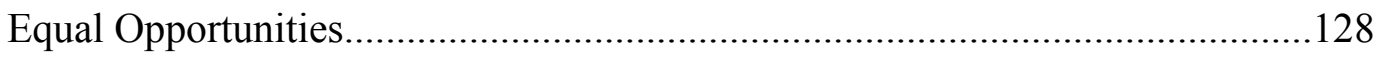

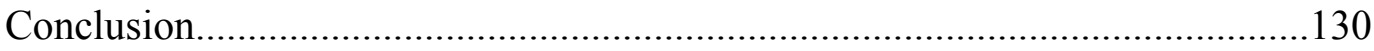

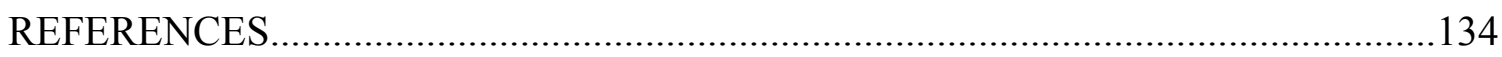

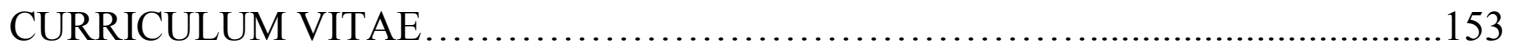




\section{CHAPTER ONE: INTRODUCTION}

In many regions of the world, women and girls struggle against masculinized social and cultural structures. This struggle takes place in their homes, neighborhoods, places of worship, schools, and offices. However, nowhere is the lack of female voices

more apparent than in the political arena (deAlwis et al. 2013). By extension, women are also routinely blocked from participating in international peacemaking and peacebuilding processes. In various African countries, governments and warring parties frequently attempt to sideline women. For example, during a round of peace proceedings in the Democratic Republic of Congo, government representatives insisted that war and peace are exclusively the business of men and women have no right to participate (Mpoumou 2004). In Burundi, men went so far as to tell the women gathered: "You should be at home. Peace is a men's issue" (Kadende-Kaiser 2012:137).

As a result of forced marginalization, female participation in peace processes is restricted to the feminized, less valued, informal level where they are unable to meaningfully contribute to decision making (deAlwis et al. 2013; Mazurana 2013; McKay 1998; Nordstrom 1998). This leads to the majority of women's voices going unheard during formal processes including: peace negotiations; disarmament, demobilization, and reintegration (DDR); constitution-creation; elections; reconstruction; and rehabilitation (Dyfan and Piccirilli 2004; Sjoberg 2010; Schnabel and Tabyshalieva 
2012). However, since the passing of U.N. Security Council Resolution 1325 in October 2000 , the international community is now stressing the importance of incorporating women into peace and security frameworks by codifying these processes into international law (Cohn et al. 2004; DeLargy 2013; Popovic et al. 2010; Tryggestad 2009). Eager to mainstream a gendered perspective into peacekeeping operations, Resolution 1325 concentrates on four thematic areas: gender-based violence, access to decision-making, peacekeeping operations, and DDR processes (deAlwis et al. 2013; Shepherd 2008; Willet 2010). Rather than merely considering the differing needs of females, Resolution 1325 calls for the inclusion of active female participants into peacekeeping and peacebuilding operations. This thesis focuses exclusively on the inclusion and integration of women and girls within the last thematic area: DDR. ${ }^{1}$ It is dedicated to understanding the answer to two important questions: 1) Why aren't more female ex-combatants participating in DDR and 2) What can be done to ensure that they receive the same access to DDR benefits as male combatants?

To date, the majority of scholarly works exploring DDR focus on the process from two perspectives: 1) men and 2) reintegration. DDR is generally argued to serve "boys with guns." While a number of feminist researchers have begun to combat this gender bias (Mazurana and Cole 2013; McKay 2004; Mackenzie 2009), their research also tends to focus disproportionally on the experiences of females in the reintegration stage, particularly female noncombatants. As a result of this emphasis on exploring the problems faced in the reintegration stage of DDR, an insufficient amount of research focuses explicitly on how female ex-combatants initially gain access to the cantonment

\footnotetext{
${ }^{1}$ I emphasize "women and girls" here to make it clear that girls are as involved, if not more involved, than adult women in the violent conflicts in Africa. For the sake of clarity, I will refer to them simply as "females" unless a distinction between the two is necessary.
} 
$\operatorname{sites}^{2}$ where the first two stages of DDR — disarmament and demobilization — take place (Muggah 2007a; Mazurana and Cole 2013; McKay 2004). Given the rising number of females participating in military and paramilitary forces, particularly in Africa, this lack of attention must be addressed. I use empirical evidence to argue that the current DDR models employed in Africa seriously lack a gendered perspective. These models are in need of immediate revisions if they are ever to reach the rapidly growing population of female ex-combatants who need and deserve equal access to the benefits available through participation in DDR.

First, I need to briefly explore that illusive term which has caused so much strife for scholars of DDR: combatant. What makes a person a combatant rather than a noncombatant or "camp follower"? Who deserves combatant status, and who doesn't? The literature on this topic is vast, full of dangerous theoretical and normative turns and pitfalls. For example, one dictionary definition describes "combatant" in noun form as "a person engaged in conflict or competition with another," however, when used as an adjective, "combatant" is defined as "engaged in fighting during a war." According to the Third Geneva Convention, a combatant is someone who takes a direct part in the hostilities of an armed conflict. Using the technical jargon of the Third Geneva Convention, there are two types of combatants: privileged and unprivileged. A privileged combatant is someone who qualifies for prisoner-of-war status in the event of capture. These combatants are generally known members of armed forces or militias that: 1) are commanded by a person responsible for his subordinates, 2) have a fixed distinctive sign recognizable at a distance, 3) carry arms openly, and 4) conduct their operations in accordance with the laws and customs of war. An additional protocol signed by many

\footnotetext{
${ }^{2}$ Cantonment sites are the barracks or camps where demobilization occurs
} 
countries in 1949 recognized combatants who do not wear any distinguishing marks as still eligible for prisoner-of-war status.

An unprivileged combatant—also called an unlawful combatant, illegal combatant, or belligerent - is defined by the Third Geneva Convention as someone who does not qualify for prisoner-of-war status. There are several types of unprivileged combatants including: mercenaries, combatants who have breached the laws and customs of war, spies, child soldiers, and civilians active in the conflict. However, the Geneva Convention is only applicable in conflicts involving two or more nation states, so for the internal conflicts of countries in Africa, the distinction between privileged and unprivileged combatants is not upheld.

When it comes to women as combatants, scholars like Cohen (2013:383) argue that "the tendency is to take for granted that women do not participate in acts of violence, whether by choice or because women are assumed to play merely supporting roles to their male counterparts." In this sense, most women in armed conflicts would be placed into the unprivileged combatant category as civilians; and girl soldiers seem to be twice marginalized, first as women but also as children. However, as the research in this thesis will show, females serve in a variety of active combatant roles as well as vitally important martial auxiliary roles - particularly females in the conflicts in Africa - that extend well beyond the realm of cooks, cleaners, and sexual slaves. Therefore, when the integration of "combatants" in African DDR processes is discussed, both by me and other scholars, the consensus seems to be that both privileged and unprivileged combatants should qualify. After all, a major element of most DDR processes in Africa is removing child soldiers from fighting forces and reuniting them with their families. Unfortunately, 
as this thesis will make clear, very few cases of African DDR have actively worked to incorporate both privileged and unprivileged female ex-combatants into DDR processes.

There are a number of reasons why the DDR process is appealing to excombatants, both male and female. Not only can ex-combatants receive immediate cash payment for each firearm handed in (Muggah 2007a; Willibald 2006), but they can also receive resettlement money, healthcare for themselves and their dependents, job training, and career counseling. In countries like Uganda, where most schools are private and expensive, the DDR program even paid school fees for ex-combatant children for an entire year (Kingma 1997). Furthermore, child soldiers and victims of violent rape and sexual violence can also receive long-term counseling and medical care (Mazurana and Cole 2013; Willibald 2006; McKay and Mazurana 2004; Kingma 1997).

With so many benefits to be had in completing the DDR process, a number of African countries have struggled to meet the needs of the target population. In many cases, desperate civilians pose as ex-combatants and attempt to gain entry to cantonment sites (Jennings 2007). From Mozambique to Sierra Leone, this has led to a number of highly restrictive entry measures being put in place, including limiting access to officers, limiting access to only those combatants who show high reintegration potential, or only allowing those soldiers in possession of an AK-47 assault rifle to enter (Mazurana and Cole 2013; Willibald 2006; Muggah 2007a).

This last measure is particularly troubling since, in the history of civil war and violence in Africa, the weapon of choice has often been the machete, not the AK-47. For example, during the Rwandan genocide, which lasted only 100 days, the number of people killed by machete represented 52 percent of the total death toll of nearly one 
million people. Since 64 percent of rural households in Rwanda owned at least one machete, it was only natural that this became the weapon of choice. In fact, gun deaths accounted for only 14.7 percent of the deaths during the genocide. It was more likely for a Rwandan to be killed by a club than a gun in the initial days and weeks of the genocide, with more routinized mass killings by firearms happening much later (Verwimp 2006).

While the Rwandan genocide is the most chilling example of rudimentary weapons being used in a modern African conflict, the machete is still used widely throughout Sub-Saharan Africa. Following the strict DDR guidelines put in place by countries like Sierra Leone, countless perpetrators who wielded a machete and not a gun would be excluded from DDR services. By limiting access to DDR in such a way, scores of male and female combatants become marginalized (Mazurana and Cole 2013; Mazurana and Carlson 2004; UNDPKO 1999). To understand just how many female excombatants are possibly marginalized, we need to know more about the participation of women in violent conflicts.

\section{Women in Violence and Conflict}

Feminist scholars have been studying the specific effects of violence by women and on women for decades (DeLargy 2013; Enloe 2000b; Mazurana 2013; RavenRoberts 2005; Mazurana and Cole 2013; McKay 1998; Nordstrom 1998; Sjoberg 2010). However, to understand the effects of violent conflict on women, more must be said about the difference between "violence" and "conflict." From a theoretical standpoint, violence and conflict are not the same thing. As such, they are experienced and understood differently. Conflict can be nonviolent, whereas violence, by definition, 
involves the use of force, be it physical or psychological, direct or indirect (Moser and Clark 2001). Drawing on the work of Johan Galtung, Giddens (1999) argues that violence is any barrier which impedes the realization of potential, where such a barrier is social rather than natural. For example, if people are starving when this is objectively avoidable, then violence is committed. Furthermore, violence is fundamentally concerned with power, and gender-related violence embodies and exploits the power imbalance inherent in a patriarchal society like that which permeates the majority of Sub-Saharan Africa. However, as Goldblatt and Meintjes (1998) explain, women's experiences of violence, particularly gendered violence, cannot be understood in isolation from men's experiences. Women's experiences with violence are a direct consequence of the interrelationship of women's and men's roles and statuses in society. The edited volumes by Cohn (2010), Turshen and Twagiramariya (1998), and Lorentzen and Turpin (1998) provide excellent overviews to a number of issues related to women in violent conflicts including: resistance movements, wartime motherhood, truth and reconciliation commissions, sexual violence, and post-war grief and mourning. Another exceptional edited volume, by Moser et al. (2001), examines the multiple roles of women as victims, perpetrators, and actors in armed conflicts and political violence around the world from Mozambique and Rwanda, to Croatia, Israel, India, and El Salvador.

While research on the effects of violence on noncombatant women is readily available, few scholars focus their attention specifically on the integration of females within military operations. According to Enloe (1993), political violence and armed conflict have long been seen as male domains, executed by men, whether as armed forces, guerilla groups, paramilitaries, or peace-keeping forces. Statistically speaking, 
men are overwhelmingly the perpetrators of violence, while both men and women are the victims of this violence (Moser 2001; Cockburn 2001; Coulter et al. 2008). Various theories attempt to make sense of why women are seemingly more peaceable than men. These theories highlight women's natural aversion to risk and their traditional gender roles as mothers, caretakers, and nurturers (Daly 1984; Carpenter 2006; Carter 1998; Onyango 2005). However, to focus only on women's roles as victims in violent conflicts is to deny the experience of a growing percent of females who participate as perpetrators (Coulter et al. 2008; El Jack 2003; Moser 2001; Cockburn 2001; de Watteville 2002). Feminist researchers including Peteet (1997), Ibanez (2001), Krog (2001), and Mason (2005) have written detailed accounts of women's active participation in violent rebellions and conflicts. From Palestine to El Salvador to East Timor, this trend is not uncommon in rebel warfare. In fact, female fighters in different conflicts have been described by other fighters and civilians as more cruel and cold-blooded than their male counterparts (Coulter et al. 2008; Olonisakin 1995; Utas 2005). According to Mazurana et al. (2002), between 1990 and 2002, girls in particular were present in fighting forces and groups in at least 54 countries. Of those countries, girls were active combatants in at least 36, including Guatemala, Cambodia, Macedonia, and Iraq.

\section{Female Combatants in Africa}

In Africa, over the past several decades female fighters have been actively involved in the violent conflicts in Angola, Ethiopia, South Africa, Uganda, Zimbabwe, and many more (Mazurana et al. 2002; Denov 2004). For example, during the civil war in the Democratic Republic of Congo, nearly 20 percent of the government military was 
composed of women soldiers (Puechguirbal 2003). In Eritrea as well, females make up one-fifth of the armed forces, totaling roughly 13,000 women (Lindsey 2000; Klingebiel et al. 1995). Comparatively speaking, more women participate in non-state armed groups (NSAGs) than in government forces and militias. However, since NSGAs do not keep detailed records it is difficult to know the exact percentages of women fighters. For example, it is estimated that the Revolutionary United Front (RUF) in Sierra Leone was made up of at least 12 percent women (Knight 2008). Across Africa it is estimated that female combatants can make up as much as 30 percent of fighting forces, military and paramilitary (Mazurana 2004; Coulter et al. 2008; Denov 2009). Young girls are especially targeted by rebel groups. According to the Coalition to Stop the Use of Child Soldiers, girl combatants made up between 30 and 40 percent of all child soldiers in the conflicts in Angola, Ethiopia, Sierra Leone, and Uganda (Mazurana et al. 2002).

Some of the more recent works examining the roles of females combatants in perpetrating violence include Mazurana and Carlson (2004), Mpoumou (2004), Cohen (2013), and Peters and Richards (1998). The issues examined by these scholars include women in combat (Mazurana and Carlson 2004; Peters and Richards 1998) wartime rape (Cohen 2013; Carlson and Mazurana 2008; Turshen 1998), mothers in war (Onyango 2005) and women in peacemaking (Mazurana 2005b; Mpoumou 2004). For those serving as active combatants, exceptionally talented female often find their way into high ranks. For example, in Northern Uganda's Lord's Resistance Army (LRA), they served as captains, lieutenants, even corporals (Denov 2009). Female officers are responsible for training new recruits, gathering intelligence, and serving as spies, medics, first aid technicians, and weapons experts. One girl in Sierra Leone explains: 
I became a soldier and later a commander. My job was to mobilize soldiers and lead them to fight...As a commander, I had six [child] bodyguards who protected me...I was a commander not only for children but even for some soldiers (Denov 2009:10).

Steeped in a collective purpose and power, many young females in Africa are raised within subcultures that promote cruelty and militaristic violence. Often the more violent they are the more they are prized and protected by their commanding officers.

Furthermore, in countries like Sierra Leone, the more violent you behaved the better access you were granted to food and looted goods. One girl solider in Sierra Leone explains:

I didn't have the mind to kill someone initially...but later on I enjoyed the wicked acts...I was responsible for killing anybody that was assigned to die. I was so happy and vigilant in carrying out this command (Denov 2009:9).

Another female RUF soldier clarifies:

Our only motive to exist was killing. That is the only thing we thought about...I burned houses, captured people, and I carried looted property. I was responsible for tying people, and killing. I was not good at shooting, but I was an expert in burning houses (Denov 2009:9).

Cohen's (2013) work is particularly interesting in this analysis of the disarmament and demobilization of female ex-combatants because she examines the roles of women as perpetrators of sexual violence during wartime. Through in-depth interviews and survey data, her study of wartime rape during the civil war in Sierra Leone demonstrates just how violent women can be as both the instigators and willing accomplices in the brutal rape of noncombatants. Additional research seems to support the conclusion that this phenomenon is on the rise. For example, in a population-based survey conducted in 2010 in the DRC, 41 percent of women surveyed reported that they were victimized by other females. Of the male victims, 10 percent said it was at the hands of a female perpetrator 
(Johnson et al. 2010; Cohen 2013). In Liberia, women were routinely implicated in the rape of other women, including rape with objects such as guns, and in sexual crimes against men, namely cutting off the genitals (Specht 2006; Advocates for Human Rights 2009; Cohen 2013). Female-perpetrated sexual abuse is a trend found outside of Africa as well. Perhaps the most famous recent example of female-perpetrated sexual abuse occurred at Abu Ghraib when male Iraqi prisoners were photographed being abused and humiliated by female U.S. soldiers (Cohen 2013).

While more and more women are participating in violent conflicts, most African countries have yet to establish a positive record for integrating female ex-combatants into DDR processes. As one World Bank report admitted, DDR tends to focus solely on "young men with guns" (Knight 2008:44). Mazurana and Cole (2013) provide a number of recent examples of this phenomenon. In Angola, only 60 females, representing 0.2 percent of the estimated size of the Union for Total Independence of Angola (UNITA), were identified through DDR, even though numerous media and human rights organizations remarked on the high number of women active in the organization. For example, girls made up at least 30-40 percent of fighting forces (Mazurana et al. 2002). In Burundi, by October 2005, the government had demobilized 14,000 fighters out of an estimated 85,000; only 3 percent were women. During the Republic of the Congo's DDR process, a combined total of 4.6 percent of all demobilized combatants across three separate stages were women. Finally, in Rwanda, the national DDR process reached only 334 female combatants, equaling 0.06 percent of the total group registered with the program. Reading these figures, a few important questions arise: Why aren't more female combatants participating in DDR processes? Are they simply not interested in 
demobilization and social and economic reintegration? If they are interested, what are the barriers restricting female access to these processes?

\section{Where are the Women in DDR?}

Many recent studies conducted on DDR in Africa examine the process from both qualitative and quantitative perspectives by utilizing some combination of survey research, quasi-experimental designs, intensive field work, and in-depth interviewing of bureaucrats and ex-combatants (Knight and Özerdem 2004; Muggah 2007a; Willibald 2006; Pouligny 2004; Nichols 2011). This mixed method approach to data-gathering and analysis allows scholars to promote empirically verifiable and theoretical generalizable hypotheses about DDR (King et al. 1994; Johnson and Reynolds 2012). For example, scholars like Weinstein (2007), Pugel (2009), and Gilligan et al. (2013) utilized variations of large scale surveys and quasi-experiments to evaluate the reintegration of ex-combatants in the DDR process in Sierra Leone, Liberia, and Burundi, respectively. In his work on the Sudanese DDR process, Nichols (2011) examined programmatic DDR design and implementation through a series of in-depth interviews.

However, only a select few scholars are emphasizing the importance of analyzing and evaluating DDR processes specifically for female ex-combatants in Africa (Annan et al. 2011; Barth 2002; Corbin 2008; Mackenzie 2009; Mazurana and Cole 2013; McKay 1998 and 2004; Smet 2009). Barth (2002) completed one of the first comprehensive studies of women combatants in DDR. Funded by the Peace Research Institute, her work provides a comparative analysis of the reintegration of female soldiers across a number of African countries. In a more recent study, Mazurana and Cole (2013) outline a number of 
DDR processes that attempted to integrate women including Mozambique, Sierra Leone, Angola, and Burundi. They seek to answer an important question that I echo here: Where are the female ex-combatants in DDR?

As my research in the following chapters will show, there are a number of reasons why females are not interested in completing the DDR process, including fear of undergoing medical treatment, and fear of being sexually harassed or abused while being demobilized. Still more women avoid official DDR programs because they want to break their connection with armed forces and groups as soon as possible and return to civilian life; Mazurana and Cole (2013) refer to this as "self-demobilization." For example, in their quantitative study on the reintegration of ex-combatants, Humphreys and Weinstein (2007) found that females were far more likely than males to break all group ties with former combatants. Furthermore, many women self-demobilize because they are under intense pressure to convert back into the gendered status quo and assume their "proper" place within their family and community structures (McKay 2004; McKay and Mazurana 2004; Mazurana and Cole 2013; Mazurana 2004 and 2005).

However, research by scholars like De Watteville (2002), Mackenzie (2009), and Mazurana and Cole (2013) shows that many female combatants would rather participate in the DDR process if given the chance. A major challenge for women is the simple lack of communication from their officers as to where to go and what kind of weapon or documentation to bring in order to be demobilized. For example, most girls in Sierra Leone did not even know DDR existed; the majority of them simply returned to their communities in a move referred to by scholars as "spontaneous reintegration" (McKay 2004; De Watteville 2002; McKay and Mazurana 2004). While simple lack of 
communication between females and officers results in low female turnout, sometimes the conduct of officers can be more underhanded. A number of female combatants cited problems with superior officers removing names from military lists and replacing them with the names of the officer's own family members. Still more are tricked into handing over weapons to senior officers prematurely; officers take the weapons and pass them off to family members, allowing them access to cantonment sites instead of the female combatants (Mazurana and Cole 2013; De Watteville 2002; Mazurana 2004, 2005). If the women are not tricked into giving up a weapon or removed from military lists, they rely on the support of their superior officers to confirm their rank to DDR personnel. However, many women serve in unofficial capacities without a rank. If they do have a rank their male superiors are often reluctant to admit it as this would recognize the importance of women to the war effort (De Watteville 2002).

Understanding where the women are and why they are not participating in DDR becomes even more complex when you take into account the number of females that are forcibly recruited to join armed forces and rebel groups; women that would definitely fall under the unprivileged combatant category as civilians. These women often play no active military role, and yet they spend years living in the bush, traveling with rebel groups and bearing them children (Mazurana and Cole 2013). For example, during the protracted civil war in Mozambique which lasted nearly thirty years, the Renamo (Resistência Nacional Moçambicana) rebels were notorious for abducting females and holding them captive. When the United Nations Development Programme (UNDP) was brought in to decommission the fighters in the early 1990s, UNDP personnel told harrowing tales of Renamo officers dragging bound women with them out of the bush, 
claiming them as wives. The women shouted things like, "He's not my husband!" and "I want to go back to my home!" before being carted away like chattel by their captors (Jacobson 2005; Mazurana and Cole 2013; Antonio de Abreu 1996).

Captured females serve in a variety of capacities in rebel camps as cooks, laundresses, food gatherers, and spies (Mazurana 2013; Nordstrom 1998; Small Arms Survey 2008; Coulter et al. 2008; Mazurana and Cole 2013). Many females excel at their domestic duties to avoid being sent into combat or to the beds of other soldiers (Denov 2009). Across Africa, females remark that a major duty is carrying the heavy loads of small arms, ammunition, food, and looted property from camp to camp (Denov 2009). An Angolan girl interviewed by Stavrou (2004) explained:

Life was just walking from one place to another, by day and by night...my children were young and should not have been walking like that...At first you were crying, but then you had no more tears left (Denov 2009:8).

However, females are most often kidnapped and forced to perform sexual favors. Many serve as "bush wives" locked into "AK-47 marriages" to various rebel soldiers (Turshen 2001; Moser 2001; Denov 2009). As one female commander in Mozambique explained, "the women's detachment tasks include cooking, tending the wounded, having involuntary sex, and carrying military equipment" (De Watteville 2002:3; Barron 1996). Younger females are most frequently used by rebel organizations as rewards for male commanders to be used as sexual and domestic slaves (Mazurana et al. 2002; Sommers 1997; Stavrou et al. 2000). An RUF soldier in Sierra Leone explained, "When one of the commanders proposed love to you, sometimes you had to accept even if you really were not willing to cooperate. This was preferable to being gang-raped" (Denov 2009:14). 
Another girl in Angola lamented, "Living in the bush is like being a slave, it's real slavery" (Denov 2009:7; Stavrou 2004).

However, as Mazurana et al. (2002) explain, gender does not necessarily dictate roles within fighting forces and groups. For example, in African countries like Liberia and Uganda, while most girls did experience sexual violence and most boys were used as front line fighters, some boys were forced into sexual servitude while girls served on the front lines (Mazurana et al. 2002; Thompson 1999). Furthermore, not all captured females are victims. Refusing to be victimized, many found ways to avoid sexual harassment and abuse. For example, girls would often wear a pad as if they were menstruating to dissuade soldiers from raping them. Other brave women fought back.

One girl in Sierra Leone admitted:

I stabbed one guy to death-he was always harassing me for sex. On that day he wanted to rape me and I told him that if he tried, I would stab him...As he attempted to rape me I stabbed him twice...I was tired of the sexual harassment. He later died [from the stabbing] (Denov 2009:16).

For women who secured "bush marriages" with senior officers, they were accorded the same respect and status as their husbands. In this way, a number of women living in camps were actually much better off than the majority of the men and boys they lived and fought beside (Denov 2009).

\section{Why should We Care about Female Combatants?}

Recognizing the plight of female noncombatants in African post-conflict reconstruction processes is vitally important for understanding the roles of people in conflicts as a whole. The majority of feminist research conducted on women in DDR 
tends to focus on noncombatants (Annan et al. 2011; Antonio de Abreu 1998; Burman and McKay 2007; Carlson and Mazurana 2008; Coulter 2009; Denov 2006). However, we cannot focus too much attention on the plight of female noncombatants at the expense of deepening our understanding of the roles and experiences of female combatants. Therefore, in this thesis I look specifically at the ways in which female ex-combatants are marginalized from the DDR process in Africa. The use of females as soldiers in African political conflicts is only growing (Lindsey 2000; Klingebiel et al. 1995; Knight 2008; Mazurana 2004). As a result, scholars and policy analysts must broaden the scope of topics researched on females who balance the roles of both victim and perpetrator to determine if these policies help or hinder female combatants. The main impetus behind this particular project is in understanding the answer to two questions: 1) Why aren't more female combatants participating in DDR and 2) What can be done to ensure they receive equal benefits as male combatants? The goal of this chapter was to lay the appropriate groundwork for answering these questions; the remaining chapters will add to the discussion.

Chapter Two, Understanding DDR, examines the DDR process as a whole, answering the vital question: what is DDR? Each stage of the process-disarmament, demobilization, and reintegration — is broken down and analyzed to determine exactly what happens and, in some cases, what should happen. Through this examination I highlight some of the main issues and problems typically cited in DDR research, including an inherent gender imbalance, the cash-for-guns scheme, reintegration constraints, and gendered security concerns within cantonment sites. 
In Chapter Three, Literature Review and Methodology, I critique the scholarly work conducted on DDR policy design and implementation, identifying common trends in the current research, namely a preoccupation with understanding how ex-combatants are reintegrated and rehabilitated into civilian society (Barth 2002; Corbin 2008; Gilligan et al. 2013; Jennings 2008; Peters 2006). Here I expose my work as unapologetically normative: the DDR process as it currently operates in Africa is broken. It does not reach the target population. Likewise, the scholarly work examining DDR is limited by a blatant gender bias and a narrow focus on reintegration. What is needed is a gendered analysis of the initial stages of the DDR process to determine where and how the policy is first designed or implemented in a way that sidelines female combatants. Therefore, I designed a qualitative study of four African cases of DDR to determine where and how the process is going wrong, beginning with the formation of the DDR policy. The countries included in this study are Sierra Leone, Liberia, Burundi, and South Sudan (PAM 2012).

Chapter Four, DDR in Four African Case Studies, presents each case study, providing a detailed account of how female combatants access cantonment sites to be disarmed and demobilized. Utilizing data collected through primary and secondary sources, I draw on these examples to highlight shortcomings to the overall design and implementation of DDR for female combatants (PAM 2012; Mazurana and Cole 2013; Antonio de Abreu 1998; Muggah 2007b; Nichols 2011; Mackenzie 2009; Smet 2009; Waters and Call 2008; Williamson 2006). Cognizant of the shortfalls and failures of previous DDR processes, the final chapter, Policy Recommendations, outlines important 
policy recommendations for future African countries faced with developing, staging, and implementing DDR processes for male and female ex-combatants.

My research addresses the problem of DDR policy in the African context, therefore the policy recommendations I postulate would be ideally implemented in similar cases of DDR operating across the continent. However, these policy recommendations are not necessarily limited to modern African wars and political violence. Indeed, the importance of this research is that it highlights structural changes to DDR policy that could potentially be implemented in similar cases around the world of post-conflict peacebuilding and reconstruction where the disarming, demobilizing, and reintegrating of female ex-combatants is necessary. 


\section{CHAPTER TWO: UNDERSTANDING DDR}

\section{What is Disarmament, Demobilization, and Repatriation (DDR)?}

According to the Uppsala Peace Agreement dataset, 36 percent of peace agreements struck in the 1989-1999 period contained specific provisions for the disarmament, demobilization, and reintegration (DDR) of ex-combatants (Gilligan et al. 2012). In the period 2000-2005 this figure rose to 59 percent (Högbladh 2011). From El Salvador to Mozambique, Cambodia to the United Kingdom, most modern peace agreements now incorporate provisions for DDR into their framework. But what exactly is DDR? The United Nations defines DDR as:

A process that contributes to security and stability in a post-conflict recovery context by removing weapons from the hands of combatants, taking the combatants out of military structures, and helping them integrate socially and economically into society by finding civilian livelihoods (UNDDR 2006).

Typically, the general parameters of formal DDR processes are established during peace negotiations. These parameters are then formalized in peace accords (UNDPKO 1999, PAM 2012; Mazurana and Cole 2013). DDR has become a key element of the peacebuilding efforts of UN operations in El Salvador, Cambodia, Mozambique, Angola, Guatemala, and Tajikistan to name just a few (Humphreys and Weinstein 2007). ${ }^{3}$ The three phases of DDR are not discrete or independent from each other. In fact, as Knight (2008) explains, there can be - and usually is - overlap in all three phases. For example,

\footnotetext{
${ }^{3}$ W. Andy Knight (2008) provides an excellent outline to the development of the term "peacebuilding" in the UN under Secretary General Boutros Boutros-Ghali in his article for African Security.
} 
while disarmament is technically the first step for combatants, for DDR practitioners the first step after planning is to find suitable locations for DDR and begin constructing the cantonments, or demobilization sties. While cantonment sites are established, practitioners work to establish safe disposal locations for gathered weapons and armed forces and groups prepare lists of those combatants who are eligible for the process. DDR also does not occur in a vacuum, it operates in tandem with other socioeconomic and political reconstruction measures, creating a complex, multifaceted post-conflict peacebuilding and reconstruction operation.

Knight (2008) cites four realistic goals of DDR programming. First, DDR can create a secure and stable environment in which peace takes root. Second, DDR contributes to creating a climate of security between ex-combatants and noncombatants during ceasefires. Third, DDR can foster the separation of combatants and the breakup of command structures. Finally, DDR provides a face-saving process for rebel groups to lay down arms without being seen as losers. However, Knight (2008) argues that while it is a useful peacebuilding tool, DDR does not guarantee that peace will be automatic or sustained. In fact, over the years scholars have argued that despite its near-standard use in post-conflict situations, the extent to which DDR is an effective tool to achieve security and development goals remains unclear (Humphreys and Weinstein 2007). Therefore, as Correia (2009:16) explains, "It should be clear that DDR programs are not the answer to post-conflict situations...DDR buys time so that the root causes of the conflict can be addressed and peace strengthened."

As the critiques above suggest, there are very real problems with the implementation of DDR programs as they currently exist. My goal by the end of this 
chapter is to clearly outline the DDR process and its current state in modern African political conflicts in such a way that the critiques by scholars like Knight (2008), Correia (2009), and Humphreys and Weinstein (2007) are not only clear, but justified. Breaking apart the three terms comprising the DDR acronym, I want to highlight the complexity of each phase and explore some of the common problems associated with the process. For the sake of clarity, I break apart the terms in order-disarmament, demobilization, reintegration - even though, as I argue above, the stages often operate simultaneously. Each stage of the process incorporates unique problems and important ongoing discussions. Within disarmament, a common debate involves the controversial "cash-forguns" scheme. The demobilization stage is plagued by issues involving overall cantonment site design and gender-based violence within cantonments. Finally, reintegration suffers from short and long term complications including how to properly care for disabled ex-combatants, child soldiers, and victims of sexual violence. Let's begin with a breakdown of terms.

\section{Disarmament}

"Disarmament" is defined as "the collection, control, and disposal of all weapons including small arms, explosives, [and] light and heavy weapons of both combatants and civilians" (Report of the Secretary-General 2005). According to the United Nations Security Council, proper disarmament planning involves clarifying which actors are responsible for oversight and coordination, as well as establishing accurate measures of how populations are to be disarmed and the weapons collected (Report of the Secretary- 
General 2000). Once the weapons are collected, programs must be organized for their safe storage and/or destruction.

In the immediate postwar period, having a large number of ex-combatants who are still in possession of small arms and light weapons (SALW) poses a serious threat to the security of a state. The machete may still be widely used in Sub-Saharan Africa, but the proliferation of SALW should not be taken lightly. According to the Institute for Security Studies (ISS) of South Africa, Africa has suffered 5,994,000 fatalities in the past fifty years due in large part to SALW. Estimates of the number of SALW in circulation range from 100 to 500 million, with 50 to 80 million being AK-47s (Knight 2008). In countries like the DRC and Burundi, it is estimated that there is at least one AK-47 per household (Edmonds et al. 2009).

Since females make up as much as 30 percent of fighting forces, they are directly impacted by legislation designed to remove weapons from combatants. In their groundbreaking work, Farr et al. (2009a) examine how small arms have affected women in conflicts around the world, as both victims and perpetrators. Farr et al. (2009b) argue that it is not only the domestic impacts of SALW on females that are currently ignored, but that the drafters of international agreements on SALW have made little significant effort to align their work with documents such as Security Council Resolution 1325 (2000), which calls for the inclusion of women in all aspects of peacebuilding, including small arms control. Some of the topics explored by Farr et al. (2009b) include sexualized violence, the role of SALW in fragmented societies, SALW in the domestic sphere, and the complexities of weapons collection. For example, in her research on the civil wars in the DRC, contributing author Szesnat (2009) argues that small arms often take on more 
than a military role in the hands of combatants, including the use of small arms as a penetrating device in the systematic rape of civilian and combatant women. Some of the other African case studies examined include Mali, South Africa, Uganda, and Somalia.

\section{Cash-for-Guns in Africa}

One way peacebuilding practitioners have found to remove guns from the public is to provide ex-combatants with immediate cash payments in exchange for all SALW turned in (Desai 2003; Hanlon 2004; Harvey; Muggah 2007a; Willibald 2006; Mazurana and Cole 2013). The "cash-for-guns" scheme is a continuing source of debate between governments, donors, and local communities. Many scholars, including Willibald (2006), Knight (2008), and Muggah (2007a), tackle the issue of cash-for-guns in their research. Willibald (2006:316-17) provides a succinct summary of the argument:

Proponents of cash payments in DDR programmes contend that they accelerate the DDR process and ease the transition from war to peace. Sceptics, though, see them as merely rewarding perpetrators of conflicts, fuelling arms markets, and encouraging similar behavior in the future.

A number of proponents of cash-for-guns argue that without financial incentive warring parties lack the needed inducement to disarm (Tanner 1996). By providing this incentive DDR practitioners are able to convince belligerents to voluntarily disarm themselves, rather than having a government or peacekeeping organization forcibly disarm them. Preserving the voluntary nature of disarmament in the DDR process makes all the difference in terms of maintaining stability and peace (Willibald 2006; Spear 2002). Beyond removing guns from ex-combatants, a number of scholars and relief agencies see the use of cash payments as a useful development tool (Desai 2003; Hanlon 
2004; Harvey 2005). Giving cash is appealing because it allows for the purchase of goods like food, clothing, or medicine; in this way it is adaptable to the specific needs of individual beneficiaries. Cash is also easier to distribute to those who need it, allowing recipients to forgo the need to carry bulk commodities from distribution sites to their homes (Willibald 2006; Harvey 2005; Peppiatt et al. 2001). Furthermore, Knight and Özerdem (2004) argue that, in order to facilitate their acceptance by families and community members, ex-combatants cannot be seen as returning empty-handed. By providing ex-combatants with immediate cash payments, they are able to more quickly return to their homes and begin readjusting to life in their local communities.

It is important to clarify that the cash received by ex-combatants for SALW is not always equivalent to their actual value, black market or otherwise. Faltas (2001) explains that the price only needs to be high enough to make it worthwhile for people to travel to the cantonment sites and turn the weapons in. However, scholars like Kingma (1997) argue that unless the price offered is greater than the black market value, combatants will turn to the black market instead, which greatly hinders the disarming process. Both of these arguments are persuasive, but it all depends on the situation of each individual soldier and what he or she is willing to accept in exchange for their weapon. For example, during the DDR process in Liberia, a combatant outside a cantonment site told a reporter:

I still have my $81-\mathrm{mm}$ mortar, but I just come to see whether the UN was giving fighters who disarm something good; if they don't give good money, I will not give the rocket (Gilligan et al. 2012:602).

During the civil war in Mozambique, it is estimated that roughly half a million to six million weapons were imported into the country (Gamba 1999). As a result, the disarmament stage of the DDR process was a massive undertaking, with the UN Mission 
in Mozambique (UNOMOZ) collecting over 6 million rounds of ammunition, 3,677 grenades, 225,717 landmines, and 24,124 unspecified weapons (Lundin et al. 2000).

On the other side of the argument, scholars contend that providing cash to excombatants is only suitable in settings where banking systems are functioning, markets are strong, and corruption is low, which is not usually how post-conflict societies are initially described (Willibald 2006). Scholars like Knight (2008) contend that the use of cash payments has led to fraud, mismanagement of funds, and extortion. Another drawback to the use of cash includes the inherent risks for those receiving cash and those distributing it in terms of personal security. Furthermore, vast injections of cash into a post-conflict environment could also cause prices for certain goods to increase with demand, causing temporary inflation.

As scholars like Willibald (2006) and Berdal (1996) explain, one of the most serious concerns in the exchange of cash for weapons is that it can actually prompt combatants to buy newer, better weapons, defeating the purpose of the cash exchange. In the immediate post-conflict reconstruction phase, the influx of cash is perceived to fuel the creation of an illegal arms market, leading to arms being smuggled across national borders (Willibald 2006; Isima 2004; Knight and Özerdem 2004). In other instances, corrupt disarmament programs funnel collected arms that were set to be destroyed back out to local and regional buyers. This was the case in Mozambique, where a large portion of the 190,000 weapons collected but not destroyed are believed to be in recirculation (Gamba 1999; Dzinesa 2004). To combat this potential outcome DDR practitioners in El Salvador and Sudan issued vouchers rather than cash, which were exchanged for goods at markets and pharmacies (Knight 2008; Laurance and Godnick 2001; Knight and 
Özerdem 2004). In Somalia, the Unified Task Force (UNITAF) experimented with a "food-for-guns" program, but the project was abandoned when tensions mounted between UNITAF and the humanitarian agencies responsible for dispensing the food (Kingma 1997; Adibe 1995).

One final problem with using cash in DDR processes that is vitally important to this study is that it tends to disproportionately disadvantage women. As Koyama (2009) explains, while the implementers of weapons collection programs may have the political will to include women's participation, they are often not well equipped to do so. Using case studies in Albania, Cambodia, and Mali, Koyama (2009) argues that if women's involvement in weapons collection programs could be expanded and formalized, these programs will be more successful. Koyama (2009) is joined by Kinzelbach and Hassan (2009) in demonstrating the power of women in promoting and encouraging weapons collection. Civilian women in particular want weapons out of their homes and communities so they encourage male family members to give them up. However, in some areas, like Uganda, the pressure from women to disarm had a negative effect. Many men experienced feelings of emasculation through the disarmament program; men who voluntarily disarmed were frequently called "women" by others in the community (Yeung 2009). In other places in Africa, particularly in the Horn of Africa, the owning of arms is culturally accepted (Edmonds et al. 2009). As Kingma (1997:157-58) explains:

In some areas a man without a gun is not considered a "real man." Innovative ways therefore must be found to control the use of these weapons rather than taking them away completely.

For female combatants, cash-for-guns creates other problems. First, largely seen as the dependents of men, women are less able to retain control over cash as opposed to 
alternatives like foodstuffs (Willibald 2006). Second, many female combatants do not maintain constant access to SALW. If they are not in possession of a gun, they cannot turn anything in and thus cannot receive any cash payments (Mazurana and Cole 2004; Willibald 2006; Mazurana and Cole 2013; Muggah 2007a). Finally, even if they do have access to a gun, as I explained in Chapter One, female combatants are often forced or tricked into giving them to senior officers prematurely. Unaware of the rules, they arrive at demobilization sties empty-handed and are turned away (McKay 2004; Mazurana 2004, 2005; De Watteville 2002). For those few female combatants who succeed in being disarmed, the next step is demobilization, which is rife with a whole new set of problems.

\section{Demobilization}

"Demobilization" is the process by which government and/or opposition or factional armed forces and groups "either downsize or completely disband as part of a broader transformation from war to peace" (UNDPKO 1999). Through this process, the goal is take the "combatant" and turn him or her back into a "civilian" (Knight 2008). As Mazurana and Cole (2013:195) explain, "Fighters need to be demobilized so that the armed groups cannot readily start up the fighting again — and so that they can have a postwar livelihood that is not dependent on armed violence."

One of the first steps during the demobilization process is to identify the target group(s) in need of demobilization. If demobilization cannot be peacefully accomplished, namely if ex-combatants cannot be placed into employment or provided with skillstraining and education, lack of income increases their propensity to commit new crimes (Tanner 1996; Collier 1994; Knight and Özerdem 2004). Kingma (1999) cites a number 
of examples in Mozambique and South Africa where demobilized combatants felt forced to turn to banditry in order to provide for their families. This further destabilizes already fragile regions. The subtle explanation provided by a Liberian ex-combatant perhaps says it best: "You have to satisfy the ex-combatants because otherwise people will do things the other way and could spoil things" (Jennings 2007:207).

One of the most important facets of a well-designed demobilization strategy is coordination (Knight 2008). This need is reflected in the 2005 Integrated DDR Standards (IDDRS) developed by the United Nations Inter-Agency Working Group on Disarmament, Demobilization, and Reintegration (IAWG). The IDDRS are a comprehensive repository of guidelines, policies, and procedures on DDR. As Knight (2008:31) explains, "In addition to building a more effective lateral framework across the UN system, the IDDRS also seek to provide better coordination with actors on the ground." If the various government and international aid bodies representing the highly decentralized process find a way to work in tandem with each other, stability is increased. However, when these programs cannot work together chaos invariably ensues. For example, during the demobilization of rebel and military fighters at the end of the Second Congo War, at least four major national and international organizations were responsible for carving up the duties of the demobilizing and peace-building efforts in the DRC. This caused a series of implementation and oversight problems inhibiting the ability of any organization to actually maneuver within the overlapping bureaucracies and help the Congolese people (Knight and Özerdem 2004). Examples like this prove that coordination between governments, aid groups, and cantonment sites must be a top priority. 
In traditional martial vernacular, a cantonment is a military camp, barracks, or fort. In the DDR process, cantonments are established to facilitate the disarming and demobilization of ex-combatants. In most countries, numerous cantonment sites are created in order to meet the needs of the target population. In Sudan and South Sudan, as of January 2011, a combined fifteen cantonment sites were either in the completed, operating, or planned stages, with some sites processing as many as 10,000 combatants (Nichols 2011). In the aftermath of the war in Angola, thirty-five cantonment areas registered upwards of 85,000 combatants (Knight and Özerdem 2004). During cantonment, ex-combatants, and sometimes their families, are held together in barrackslike quarters to receive health screenings, job or skill training, material goods, and cash payments (Mazurana and Cole 2013; Willibald 2006; McKay and Mazurana 2004). In Uganda ex-combatants and their dependents went through pre-discharge briefings, providing details on how to open a bank account, how to start income generating activities, environmental and legal issues, family planning, and HIV/AIDS prevention (Kingma 1997). By providing economic benefits, reintegration programs try to make civilian life more attractive to ex-combatants and thus reduce the risk of political disorder (Gilligan et al. 2013). For many scholars and peace practitioners, cantonment is the first and also the most critical phase of the entire DDR process where both disarmament and demobilization often take place simultaneously. If cantonment fails, not only is the disarmament and demobilization process at risk, but the entire peace process as well (Gleichmann et al. 2004).

Once ex-combatants arrive at cantonment sites, the first step is to complete the registration process and be issued an ID card. This process is crucial because it gives the 
ex-combatants access to all DDR benefits. In many DDR processes, the issuing of IDs can complicate the demobilization process for women. For example, in the case of husband-wife combatants, some DDR programs only issued one ID to the male combatant, leaving the female completely dependent on him for all aid benefits (De Watteville 2002). In other cases, like in Mozambique, abducted women were processed with their captors under his ID, even when they vocally objected to being linked to him or explained that they were in no way related to him (Mazurana and Cole 2013). This was also the case in Sierra Leone and Angola; Ms. Béatrice Pouligny, senior researcher at the Centre d'études et de recherches internationals (CERI) in France explains that female combatants in these conflicts were classified as "dependents," precluding them from receiving any ex-combatant benefits (Harsch 2005). While the issuing of an ID is imperative for female ex-combatants in order to receive benefits, many are fearful of being processed because it would mean they would carry around a picture ID forever marking them as a rebel. For women who just want to move on with their lives, foregoing DDR and the cantonment process can be safer than admitting to their role in the violence (Friedman-Rudovsky 2013).

According to Berdal (1996), Colleta et al. (1996) and the UNDPKO (1999), the potential benefits of cantonment are three-fold. First, it provides a number of operational opportunities: by registering ex-combatants and gathering personal information to profile them we are able to learn about health risks, paint a clearer picture of combatant activity during the war, and identify vulnerable groups like child soldiers, women, and persons with disabilities. Health facilities within cantonments are often equipped to screen excombatants for HIV/AIDS and other sexually transmitted infections (STIs); they teach 
basic hygiene and sanitation principles; and health practitioners recommend appropriate benefits to meet the needs of ex-combatants and their families (Berdal 1996; Colleta et al. 1996; De Watteville 2002).

Second, cantonment allows for pre-discharge orientation sessions where excombatants and their families can receive skills training and job placement before receiving transportation home. In places like Mozambique where women did not go through demobilization, they did not receive any of these benefits, particularly the funds necessary to return home. As De Watteville (2002:8) explains, "transport fares to the province[s] were exorbitant, and many female ex-combatants could not make the trip." Third, from a more political point of view, the demobilization sites offer a clear demonstration of a belligerent group's commitment to peace; all the while keeping the fighting forces together and ready for quick remobilization should the peace agreement fail (Knight and Özerdem 2004).

While there are certainly benefits to cantonment, there are also many reasons why the cantonment process - as it currently operates - is problematic. First, cantonment sites are not always equipped to handle the influx of dependents that arrive to be processed with the ex-combatants. It is too costly to allow dependents to gain access to cantonment facilities (De Watteville 2002), which often leads to the creation of sprawling, semipermanent tent cities around cantonment sites (Last 1999). While families sit and wait for their soldier to be released, issues concerning crime, sanitation, and food and water shortages quickly multiply. For example, in Angola the original plans in 2002 were made for the processing of 50,000 former National Union for the Total Independence of Angola (UNITA) combatants. However, as Knight and Ozerdem (2004:508) explain, "More than 
85,000 UNITA combatants were registered in thirty-five cantonment areas while approximately 280,000 family members were gathered in family reception areas." Not only did the mass influx of people to the cantonment sites cause serious delays to the DDR process, but it resulted in a dire humanitarian crisis for Angola in a time when the country was not yet stable enough to handle it (Porto and Parsons 2003).

This leads to the second problem with cantonment. Living conditions are very poor. As one commander of the leading insurgent forces in Burundi explains:

[W]omen are not involved in the DDR policy or process, and thus cannot represent women's needs. The result is that there are very poor conditions for women in the cantonment camp; there is no balanced nutrition, no clothes for women, no toiletries, no feminine hygiene supplies (Mazurana 2004:63).

Her point regarding a lack of proper clothes for women is significant in the African context. In most African countries, like Burundi, there are very strict sociocultural rules about how men and women should dress, namely, women do not wear pants. However, as members of the fighting forces females were required to wear pants as part of a military uniform. A vital element of a female ex-combatant's transition back into civilian life is the donning of a skirt or dress. When they are denied access to skirts and dresses, they are viewed by the community with distrust and fear. In a very real way, the continued wearing of pants remains as a visual reminder of the fighting and of women's roles in that violence (De Watteville 2002). As one Burundian woman who could not afford to buy a skirt explained, "People were afraid of me, as if I was going to throw grenades at them or burn down their homes" (World Bank 2013). The female commander also mentioned feminine hygiene products. Another concern for many women within cantonments is the return of their menses and resulting hygiene concerns. As Mazurana et al. (2002) explain, 
menses usually stop during the conflict as a direct result of malnutrition and trauma. Once the women are stabilized within cantonments and they receive proper medical attention and nutrition, feminine hygiene becomes a concern. Lack of access to clothing and hygiene products causes embarrassment, even mental distress for females when their private reproductive processes become public (De Watteville 2002; Mazurana et al. 2002).

The third issue with cantonment occurs when demobilization drags on for too long. In cases like Mozambique, demobilization lasted for several months. As the demobilization phase extends from days to weeks to months, conditions within cantonment sites grow steadily worse. Provisions for food, water, shelter, and basic sanitation become limited. The longer people are kept contained, the more likely they are to suffer from depression and show signs of aggression and violence (ICIHI 1986). In her analysis of demobilization programs, De Watteville (2002:6) explains: "Soldiers became increasingly aggressive, stressed by immobility, inactivity, and poor camp facilities." The World Bank (2003) reported that conditions in the demobilization camps in Angola were extremely poor. As a result, many soldiers prematurely left the program, taking their weapons with them (Kingma 1994). In Liberia, deadly riots broke out at the only operating cantonment site, halting the DDR process for months until the area stabilized (Jennings 2008). The key then to a successful cantonment is to process as many people as possible in as short amount of time as possible. Here again, the better the coordination is between all the various camps and agencies responsible for demobilization, the smoother the process should go for all involved. 


\section{Cantonments, Women, and Sexual Violence}

Inherent lack of security is another serious problem within cantonments that almost exclusively concerns women. Many female ex-combatants and dependent noncombatants who voluntarily enter DDR camps become victims of sexual harassment, and in extreme cases, molestation or rape (Kingma 1997). To address violence against women within cantonments, a number of African countries have designed cantonment sites that segregate male and female populations (Nichols 2011; Jennings 2007, 2008). Other DDR programs find ways around cantonment for female combatants. In Ethiopia, women reported to their communities for ex-combatant registration, not to cantonment sites (Knight and Özerdem 2004).

However, women's trepidation to enter cantonment sites extends beyond the fear of sexual harassment or rape. Many women enter sites as long-suffering victims of sexual violence. Whether through cohabitation, sexual extortion, or forced sexual "consent," many female soldiers are victimized by members of the very organizations they serve and protect (Twagiramariya and Turshen 1998). Teckla Shikola, a Namibian woman and former soldier in Angola spent eight years in the military and saw firsthand how female soldiers were treated. According to Shikola (1998), officers routinely used female subordinates for sex. After nearly a decade of fighting, some officers had as many as 1518 children by different women, and the mothers of these children rarely knew which of the officers had fathered her child. For many women, becoming pregnant is the only way to be removed from the front lines. In this way, pregnancy protects female soldiers from the threat of imminent death at the hands of the enemy and further unwanted sexual advances at the hands of their commanding officers (Shikola 1998). 
Females who have been the target of repeated sexual abuse can exhibit a number of physical problems including abdominal pain, cervical tearing, bleeding, and infection (ISIS 1998). Forced sex can also result in the spreading of sexually transmitted infections (STIs) like syphilis, gonorrhea, and HIV (Mazurana et al. 2002). In Sierra Leone, health workers estimated that 70 to 90 percent of rape survivors tested positive for STIs. A health worker at a hospital in Uganda reported on the status of female combatants in the Lord's Resistance Army (LRA):

Women got huge swellings in their private parts whose tips resembled those of pineapples. Perhaps the uterus crumbled and got deformed due to over-penetration by too many men, which also resulted into premature births, abortions, and vaginal sores. Many young girls died after being raped and those who survived suffered complications during menstruation, got torn, and some eventually failed to conceive or bear children (ISIS 1998:51-2).

Furthermore, according to their study conducted in Northern Uganda, McKay and Mazurana (2004) found that 37 percent of girl respondents, including nearly all the girl mothers, were pregnant with children conceived in captivity. For females who give birth in the bush with no medical assistance, they arrive at cantonment sites with serious damage to their reproductive systems. In Sierra Leone a common birthing practice was to jump on the abdomens of pregnant girls who were in labor to force the baby out or to tie a laboring woman's legs together if the group was on the move, keeping the baby inside (Mazurana et al. 2002). Babies born under these conditions suffer unduly. Many mothers pass STIs and other infections onto their newborns. If the infants do not have STIs, they still suffer from severe malnutrition and underdevelopment; 20 to 50 percent of those infants brought to government hospitals at the end of the fighting in Sierra Leone were already dying (Physicians for Human Rights 2000). 
In most African countries, there is a stigma attached to rape and single motherhood, leaving women reluctant to talk about it, even to medical staff (Burnet 2012; Twagiramariya and Turshen 1998; Card 1996; Antonio de Abreu 1996). Therefore, many female ex-combatants are fearful of entering cantonment sites because they will be forced to undergo medical treatment where the truth about their sexual abuse and the extent of the physical and psychological damage would be revealed. In Sudan and South Sudan, rape is not only a matter of shame, but also of livelihood: raped women can lose their "dowry value," making it very difficult for them to get married (Small Arms Survey 2008). In the DRC women are considered to be of no value if they have sexual contact with a man outside marriage, regardless of whether it was voluntary or not (Verhey 2004; Mazurana and Cole 2013). In Rwanda, rape is difficult to discuss because the Rwandan notion of "consent" differs so greatly from consent by Western standards. A woman's consent is implied upon marriage and only severe illness or menstruation are acceptable reasons to decline (Burnet 2012). Finally, in South Africa during Apartheid, scores of young women who were the victims of sexual torture felt forced to stay silent because words like "penis" and "vagina" may not be spoken aloud in front of adults. In the body of the initial Truth and Reconciliation Commission (TRC) legislation, the word "rape" was not even mentioned. The closest a woman could come to hinting at her rape would be to discuss "severe ill-treatment" (Krog 2001).

In most situations, evidence of rape or sexual molestation is not readily identifiable to the naked eye. However, in Africa, women's fears are intensified due to the fact that a number of rebel groups tattoo, brand, or carve the flesh of their captured women in order to permanently link them to the group (Farr 2002; Verhey 2004; 
Mazurana and Cole 2013). For example, in Sierra Leone the Revolutionary United Front

carved the letters "RUF" into the breasts of captured females to signify their ownership of them (Mazurana and Cole 2013). One girl who was branded explained:

[People] cried while they were waiting to be branded. I didn't cry openly but I cried in my heart. If you cried openly they would ask you: 'Do you want us to wash you or to brand you?' 'Washing' us meant killing. After they branded me I just cried and cried (Denov 2009:11).

To date, Africa maintains one of the highest rates of HIV/AIDS in the world. According to the United Nations Programme on HIV and AIDS (2011), Sub-Saharan Africa accounts for over sixty-nine percent of those living with HIV. Seventy percent of all AIDS deaths in 2011 occurred in Sub-Saharan Africa. Furthermore, as of 2011 HIV has infected at least ten percent of the total population in nearly a dozen Sub-Saharan African states including Botswana, Zimbabwe, Mozambique, and Namibia. With the threat of STIs so high, cantonment sites must be able to screen incoming combatantsmale and female - and provide HIV awareness and safe sex counseling. Unfortunately, until the manner in which females are screened can be improved, for many of these women it is actually easier to reintegrate if they bypass the DDR process, thereby keeping the evidence of their rape or sexual molestation a secret (De Watteville 2002).

\section{Reintegration}

The last letter in the acronym DDR is the most misunderstood of the three terms. Alternatively described by various sources as reinsertion, repatriation, or rehabilitation, the " $\mathrm{R}$ " in DDR is most accurately labeled "reintegration." Reintegration programs are designed to increase the likelihood that former combatants will become socially and economically active in the communities they return to and that they will resist taking up 
arms again (UNDPKO 1999; Mazurana and Cole 2013; Tanner 1996). In past DDR programs, practitioners have focused reintegration attention only on those ex-combatants with significant economic potential. Other practitioners focus on the most vulnerable populations and increase their ability to begin economic enterprises (De Watteville 2002). Either way, the proper reintegration of ex-combatants is a crucial step in promoting sustainable peace and it relies heavily on the active support of the local communities responsible for reintegrating them. If ex-combatants are not accepted back into their local communities, they have little chance of earning a living through nonviolent means (Alden 2002; Annan et al. 2009 and 2011; Jennings 2008; McKay 2004). ${ }^{4}$

Reintegration programs focus on promoting both short and long-term development and peacebuilding goals. In the short-term, DDR practitioners work to create a streamlined disarmament and demobilization process that acts to return excombatants to their homes as quickly as possible. However, there is a delicate balancing act at play here: ex-combatants must be reintegrated, but DDR programs cannot flood local communities with scores of unemployed people without first ensuring there are job opportunities and basic human needs like housing, food, and water available to them. This is what happened in countries like Mozambique and Liberia, where waves of excombatants returned to communities that had no means of supporting them. In Mozambique it led to an often circulated quip by ex-combatants: "The government told us, "now you are all equally poor. You have been reintegrated back into basic poverty"” (McMullin 2004:630). For this reason, a major aspect of short-term reintegration involves the distribution of departure packages, which include food, tools, cash, clothing, and

\footnotetext{
${ }^{4}$ Scholars like Knight (2008) and Edmonds et al. (2009) explain the significance of "reinsertion" as a necessary step between "demobilization" and "reintegration" whereby the combatant-turned-civilian goes through the formal process of reinserting into society. Once reinserted, they begin the reintegration process.
} 
vouchers to help ex-combatants and their families get back on their feet (Willibald 2006; Mazurana and Cole 2013). Other short-term goals of reintegration are caring for wounded soldiers and civilians, family reunification, and health and career counseling services (Kingma 1997; Humphreys and Weinstein 2007; Mazurana and Cole 2013).

One of the immediate security problems faced in the short-term is caused by excombatants who try to apply their skills outside of militaries and paramilitaries. While the UN General Assembly publicly condemns the recruitment, training, and financing of mercenaries, the use of ex-combatants as mercenaries and private security forces is increasing across Africa (Kingma 1997; Bernales Ballesteros 1994). Goose and Smyth (1994) estimate that when the Rwandan Patriotic Front (RPF) invaded Uganda in 1990, more than half of the fighters and most of the officers were drawn directly from Uganda's own National Resistance Army (NRA). Furthermore, from 1989-1998 the South Africabased firm Executive Outcomes (EO) provided South African Defense Force (SADF)trained mercenaries to perform targeted missions in Botswana, Angola, and Sierra Leone (Kingma 1997). While it was dissolved in 1998, EO was even linked to mercenary activities on Bougainville Island in Papua New Guinea, as well as Somalia and Eritrea as late as 2012 (Powell and Capazorio 2012).

In the long-term, reintegration policies can help assist with the resettling of refugees and displaced persons and the continued resettlement and socioeconomic reintegration of ex-combatants. Another goal is to promote trust-building between various ex-combatants and the community. Research shows that individuals who distrust the intentions of other groups in reintegration processes are less likely to reintegrate (Humphreys and Weinstein 2007). Finally, the long-term care of wounded, disabled, 
mentally ill, and chronically ill ex-combatants remains a priority (Mazurana and Cole 2013; Alden 2002; Annan et al. 2009; Barth 2002; Corbin 2008; Gilligan et al. 2013; Kingma 1997; McKay 2004; Peters 2007; Pugel 2009). Here again, female excombatants may face gender-biased standards. As De Watteville (2002:16) explains:

In many countries, a disabled man is able to marry a wife who can provide the labor that the man can no longer perform. In contrast, if the woman is disabled, her husband might abandon her.

The UNDP (1995) conducted a study which found that women with disabilities are more prone to divorce, separation, and violence than non-disabled women at a rate of two to one. Furthermore, disabled females are often unable to enter income-generating jobs without intensive training and rehabilitation (Mehreteab 2007). The only way for most female ex-combatants to receive disability benefits is to pass through the demobilization phase of DDR. If they are not allowed access, they cannot receive the care they need (De Watteville 2002). Without the care of a trained medical staff, many disabled female excombatants must rely on other female family members, friends, or neighbors (Krishnan 2011). For example, in their research on kinship networks in Sri Lanka, Ruwanpura and Humphries (2004) found that female neighbors and friends are vital to the recovery and reintegration of disabled female ex-combatants, providing invaluable non-financial help like childcare, chaperoning children to school, cooking, and emotional support.

There are two major economic barriers blocking female ex-combatants during the reintegration process: 1) access to land, and 2) access to credit. In many African societies, women are routinely blocked from both. As Turshen (2001:67) explains:

Women's rights to land are diminishing throughout Africa. Privatization, formal registration, and titling are part of the process of expropriating women while giving new rights to men and multinational enterprises. 
Typically far less educated than their male counterparts, many women are illiterate and they are not geographically mobile; most do not own land, and most have no form of collateral to offer loan or credit offices. Therefore, female ex-combatants must deal with high levels of discrimination and a lack of information regarding basic civil rights. As a result, many women pursuing agricultural endeavors in the countryside settle for being granted land use rights, not land ownership rights. For women with no agricultural skills, they need training in other vocations and access to credit to help them start small businesses. In some countries, like Eritrea, programs like "Barefoot-Bankers" were designed to reach the poorest and most vulnerable ex-combatants to provide them with credit opportunities. Over 5,000 of the ex-combatants were women. They were able to form lending groups where through the pooling of resources they could offer necessary collateral to receive small business start-up loans (De Watteville 2002).

\section{Reintegrating Child Soldiers}

Since so many modern conflicts in Africa involve the abduction and forced recruitment of child soldiers, family reunification is a vital service in the immediate postconflict phase (UNICEF 2005; Derluyn et al. 2004; Blattman and Annan 2010; Corbin 2008; McKay 2004; Williamson 2006). Diverting briefly from the discussion of reintegration, I want to say a few words about the use of child soldiers in the conflicts of Africa, before returning to the importance of reintegration initiatives targeting children. Peters and Richards (1998) provide several reasons why the use of child soldiers in Africa is so common. First, in many African countries the average age of citizens is quite low. With a major portion of the population under 18 -years-old, it is only natural that 
children are involved. Second, militia life offers training, livelihood, and a sense of belonging that many children lack. As comrades-in-arms, all-child units become a family substitute to which child soldiers are fiercely loyal. Third, advances in technology allow more children to participate. Battle kits were once expensive and too heavy for children to carry, but now automatic rifles are made with alloyed metals that are cheap and light enough for a 10-year-old to carry, cock, and load. Living in the bush with no supervision, stealing, doing drugs, and committing unspeakable crimes, most child combatants are unpredictable and heedless of danger, leading to high death tolls for all involved.

Knight (2008) estimated in 2008 that there were roughly 120,000 child soldiers in conflict theaters across the African continent. In most situations, girls are targeted the same as boys. However, it is only recently that the presence of girls in fighting forces has become a focus for practitioners, policy makers, and researchers (Burman and McKay 2007; Brett 2004; Fox 2004; and McKay and Mazurana 2004). In 2004, McKay estimated that in the fourteen African countries where girls made up a percentage of armed forces and rebel groups, it was only in Libya that they were not active combatants. ${ }^{5}$ Furthermore, abduction and forced recruitment of girl soldiers was the norm in all fourteen countries except Eritrea and Libya. In Sierra Leone, it is estimated that over 30 percent of child soldiers in the RUF—-broad estimates range from 10,000-20,000 children-were girls between ages 8-18 years old (Friedman-Rudovsky 2013).

McKay and Mazurana (2004) explain that the predominant pattern for coercing or abducting girls into fighting forces in Africa occurs in the home and in the school. Rebels enter communities and forcibly take individual girls from their homes or they enter

\footnotetext{
${ }^{5}$ The fourteen countries are: Angola, Burundi, Democratic Republic of Congo, Eritrea, Ethiopia, Liberia, Libya, Mozambique, Rwanda, Sierra Leone, Somalia, South Africa, Sudan, and Uganda (McKay 2004).
} 
schools and "recruit" them in larger groups. In their study in Northern Uganda, McKay and Mazurana (2004) found that 72 percent of girl respondents reported receiving weapons and military training upon recruitment. A further 8 percent of girls reported receiving advanced military training. In Denov and Maclure's (2005) study in Sierra Leone, all of the girl respondents surveyed reported receiving physical and technical training as part of their initiation into the RUF. To make them more fearless, girls were given alcohol and injected with drugs. One young soldier explained, "Before the injection [in the arm], I was nervous, afraid and unsure of myself. Later, after the injection, I felt more confident" (Denov 2009:6). To complete their training, each child was forced to kill a captive (Denov 2009; Denov and Maclure 2005).

In most cases, learning how to set an ambush and how to attack and defend a position is not enough. Children are also indoctrinated into the cause of the rebel organization. In Angola, girl fighters were forced to attend political lectures for this purpose (Stavrou 2004). In other cases, scholars like Crelinsten (1995) explain that part of the initial physical and psychological torture of new child recruits is to break down their civilian identity and build up a new identification based on the ideology and culture of the rebel group. A girl soldier in the RUF explains, "I did not willingly go and join them, but when I was abducted and my consciousness was raised about the movement, I became willing to fight" (Denov 2009:7; Denov and Maclure 2995). Once the killing becomes routinized, children come to view participation in the violence as a normative act. Another girl solider rationalizes:

Killing was just part of the normal activities of the RUF... Overwhelming the enemy was part of our job... Once you were part of the fighting force, you should be seen killing someone even without 
reason. This shows that you were committed and ready to work with them (Denov 2009:7)

A constant threat faced by girl combatants in particular is sexual violence. In Sierra Leone, most young girls recruited into the RUF were raped on their first night as a form of initiation. Laura Conreth, a former RUF child soldier who was forcibly recruited, recalls that an officer "virginated" her on her first night in the camp. At only twelve years old, Laura became the "bush wife" of a male rebel who would loan her out to other men for sex. She lived this way for three years. Fatsmata Koroma was only eleven when she was taken by the RUF; upon arriving in the camp she was gang raped by ten men. After that she was kept under constant guard by the rebels with other girls they considered to be the most attractive (Friedman-Rudovsky 2013).

Young girl soldiers who return to their families with illegitimate children are often met with suspicion and scorn because their experiences are so antithetical to traditional cultural norms (McKay 2006; McKay and Mazurana 2004; Burman and McKay 2007). One female ex-combatant explains:

Since I came back, I have not been one year with my people, but there have just been problems, problems, problems...You know, they don't love me anymore. They don't love me anymore... They despise me now (Denov 2009:22).

As a result, many girls are incapable of making the transition from soldier to civilian. Marginalized from traditional social and economic opportunities, many girl excombatants live in poverty with no educational or financial prospects. A number of them turn to prostitution. One Angolan girl noted:

Here there is no one to help me...And so I go to sleep without eating...I have no one to go to ask, because people do not give anything...I go to church but just like this (in her one set of clothes). I go because I want 
to be buried; I don't want to be buried like a dog (Denov 2009:24;

Stavrou 2004).

Boys and girls in fighting forces endure a number of hardships including deprivation of basic needs like food, water, shelter, and health care. Every day children are killed or maimed, made orphans, abducted, and left with deep emotional scars (Knight 2008; UNICEF 2005). To combat the multitude of physical and psychological issues plaguing child soldiers, DDR practitioners initiate their reintegration through counseling, group therapy, education, and healthcare as soon as a peace agreement is signed (McKay 2004). Once they are demobilized, addressing the dire nutritional needs of these children is of paramount importance. For girl combatants, a main concern is to conduct immediate health screenings to determine the extent of their sexual abuse (McKay 2004). Immediately separated from the adults they fought alongside, most DDR programs entrust the care of child soldiers to the United Nations Children's Fund (UNICEF), which is often the only organization properly trained and prepared to work with this fragile population (UNICEF 2005).

The reintegration of former child soldiers- boys and girls - is complicated by the fact that many parents do not survive to be reunited with their children. As a result, many children are forced to find kindhearted relatives or community members willing to take them in and care for them. In the immediate post-conflict reconstruction stage, most people cannot afford to feed their immediate family, let alone orphaned relatives who may display serious signs of post-traumatic stress and psychological trauma (McKay 2004; Mazurana and Cole 2013; UNICEF 2005). Since fighting usually lasts for years, sometimes decades, most child soldiers simply don't know where to begin to look to find lost parents. Therefore, various UNICEF-supported organizations conduct reintegration 
services for to help families reconnect. However, this takes time, money, and significant man hours and resources that many programs sufficiently lack (UNICEF 2005; Bonnerjea 1994; De Watteville 2002).

Most studies on girl ex-combatants focus on reintegration (Rehn and Sirleaf 2002; Verhey 2004; Mazurana and Carlson 2004; McKay et al. 2006). Their success is linked to a number of factors including whether they entered a force voluntarily or were abducted (Mazurana and Cole 2013; Rehn and Sirleaf 2002; Mazurana and Carlson 2004; Verhey 2004), how long they participated (Verhay 2001; Veale 2003), the military roles they played, and the manner of their return (Farr 2002; Veale and Stavrou 2003; Hobson 2005; Thompson 1999; Brooks 2005; Mazurana and Cole 2013; McKay et al. 2006). Girls who are gone a long time and who grew up as soldiers are often aggressive and quarrelsome; they use offensive language, abuse drugs, smoke, and kill and eat other people's animals (McKay and Mazurana 2004). One girl explains:

To cope, I take drugs; either cocaine or brown-brown. ${ }^{6}$ [When I take the drugs] I feel relieved and I don't think of any problems, no bad memories of the war, and no sadness (Denov 2009:23).

Many girls have little knowledge of traditional gender roles and fail to meet societal expectations, leading their parents and community members to treat them as outcasts (McConnan and Uppard 2001; McKay 2004; Women's Commission 2001 and 2002). Addressing the specific needs of this fragile young female population will continue to be a subject of serious interest and concern for scholars and DDR policy practitioners. The problems for most ex-combatants - male and female, boys and girls—are summarized poignantly in the words of this girl from Northern Uganda: "We return home, but to what?" (Denov 2009: 24; McKay and Mazurana 2004).

\footnotetext{
${ }^{6}$ Brown-brown is a mixture of powdered cocaine and smokeless gunpowder used widely in Africa.
} 


\section{DDR in Review}

The purpose of this chapter was twofold. First, I wanted to carefully explicate the definition of DDR, drawing specific attention to how each concept is understood and put into practice. Second, I outlined the various issues and concerns faced by DDR practitioners at each stage of the process. The overarching issue, which will be the focus of the remainder of this thesis, is the lack of a properly gendered approach to the formation and implementation of the DDR process. Put plainly, female ex-combatants are not participating in DDR at the same level in which they participate in violent conflicts. When they do participate, female ex-combatants are not receiving equal access to DDR benefits as male combatants. Furthermore, the inherent inequality between male and female combatants is greatly underrepresented in the existing DDR literature. To provide proof of this last point, Chapter Three will outline how the field of DDR research has evolved and where the focus currently lies. It is my goal to clearly outline the gendered gaps in existing research, namely as it concerns a preoccupation for understanding how male combatants are reintegrated. After highlighting existing scholarly gaps, I outline the methodology for my research design, which acts to correct this gender imbalance through a direct study of female ex-combatants and how they gain initial access to the disarmament and demobilization process. 


\section{CHAPTER THREE: LITERATURE REVIEW AND METHODOLOGY}

As Chapter Two outlined, African DDR processes have garnered significant scholarly attention over the past decade (Annan et al. 2011; Babiker and Özerdem 2003; Dzinesa 2007; Gilligan et al. 2013; Muggah 2004; Kingma 1997). For many scholars, the research focus lies in understanding the problems encountered in reintegrating excombatants (Gilligan et al. 2011; Annan et al. 2009; Humphreys and Weinstein 2007; Corbin 2008; Pugel 2009; Alden 2002; Annan et al. 2011). For example, Dzinesa (2007) provides a concise overview of a number of Sub-Saharan African DDR processes including Angola, Namibia, Mozambique, South Africa, and Zimbabwe. As Dzinesa (2007) explains, each case of DDR in Africa provides scholars and public policy analysts with empirical proof of how an ineffective DDR program can cause antagonistic armies to recidivate. Other scholars, like Babiker and Özerdem (2003), take a similar approach, offering policy recommendations for the future success of DDR processes based on research gathered from countries like Ethiopia, Mozambique, and Uganda.

While the collection of scholarly work on the reintegration of ex-combatants is comprehensive and well-researched, the tapestry created by these accumulated works is full of holes. If not filled in, these holes threaten to expose both the DDR process and the collection of scholars dedicated to examining it as gender-biased and backward-thinking. First, what do I mean by gender-biased? The bulk of the research conducted on DDR 
processes in Africa to date focuses almost exclusively on the experiences of male combatants. For example, in their research of the DDR process in Burundi, Gilligan et al. (2013) focus explicitly on the reintegration of male ex-combatants ranging from age eighteen-years-old and above with no mention of females. The studies conducted by Humphreys and Weinstein (2007) on Sierra Leone and Pugel (2009) on Liberia also do not take into account female combatants. Furthermore, Muggah (2007b), Kingma (1997), and Jennings (2008) speak only of "ex-combatants," choosing not to differentiate between the experiences of males and females. While Dzinesa (2007) admits that DDR processes must take into account the needs of marginalized groups like women, children, and the disabled, female ex-combatants are briefly mentioned only in reference to the fact that they are not mentioned in the design of the DDR processes in African countries like Zimbabwe and Namibia.

The gender bias apparent in studies of ex-combatants in African DDR processes must be addressed because the needs of female ex-combatants vary widely from those of male combatants. Female combatants have different basic health and nutrition needs; they require doctors with specialized training in conducting examinations of sexual trauma. Females need access to women's clothes and feminine hygiene products, and they need to be able to care for their children, even while being demobilized. Females also possess a different skillset than males. The educational and vocational training provided by DDR programs must therefore be adjusted to meet their abilities. Furthermore, during the reintegration process the medical care, child care, and education needs of female excombatants will be different from those of male ex-combatants (De Watteville 2002; Knight and Özerdem 2004). These are all very intuitive statements, and yet the lack of 
attention to the differing needs of female combatants by scholars and policy analysts continues largely unabated. This is detrimental to our overall understanding of the DDR process and how it helps and/or hinders ex-combatants.

Second, what do I mean by backward-thinking? The problem inherent in most of the scholarly research on DDR, besides the obvious gender bias, is that it focuses almost exclusively on the last stage - reintegration (Barth 2002; Corbin 2008; Gilligan et al. 2011; Humphreys and Weinstein 2007; Annan et al. 2009; Corbin 2008; Pugel 2009; Alden 2002; McKay 2004; Annan et al. 2011; Peters 2006). As Dzinesa (2007) explains, there is a growing gap between the two "Ds" and the "R" in DDR, leading many scholars to focus solely on why reintegration programs struggle to assist the target population. For example, Kingma (1997) and Alden (2002) focus on examining the challenges of implementing reintegration programs; Jennings (2008) and Pouligny (2004) analyze the assumptions underpinning these programs; and Soderstrom (2010) and Uvin (2007) explore individual accounts of ex-combatant experiences with reintegration. Some scholars have even amended the definition to expand this final stage calling it "DDRR", or disarmament, demobilization, reintegration, and rehabilitation (Annan et al. 2011; Knight and Özerdem 2004; Schroeder 2005). A number of studies pay particular attention to the reintegration of child soldiers including Corbin (2008), McKay (2004), and Annan et al. (2009). Recently, many scholars have lamented the lack of positive results and the poor representation of female combatants in the reintegration process (Annan et al. 2009 and 2011; Barth 2002; Corbin 2008; Gilligan et al. 2013; Jennings 2008; McKay 2004; McKay et al. 2006; Peters 2006; Pugel 2009). 
Whether through large-scale surveys, individual interviews, or experiments, scholars echo the same point: reintegration is not working. However, if scholars would simply draw their attention to the problems inherent in the initial design of DDR processes, the disheartening conclusion that reintegration does not work makes complete sense. Put plainly, it is completely backward to look to the last stage of this long and complicated three step process and conclude that reintegration is not working. When it comes to DDR, it's not that the reintegration phase does not work; the entire process is broken from the beginning. In order to try to better understand where DDR goes wrong, I want to start from the beginning, and I want to focus on the experiences of women.

\section{Start at the Source: Where does DDR Begin?}

As I outlined in Chapter Two, the DDR process begins long before the first combatant is demobilized, and definitely before the first combatant returns home. It begins when the peace process begins. Since females in the majority of Sub-Saharan Africa are sidelined from participating in peace negotiations, the disarmament and demobilization of male fighters is prioritized over the rights and needs of females, both combatants and noncombatants (Barry 2005; Mazurana and Cole 2013). While the parameters of peace agreements are codified, the role and scope of DDR processes are also set, including the definitions of combatants and eligibility requirements for entering the program. As Mazurana and Cole (2013:202) explain, "The invisibility of women and girls in formal DDR processes is often due to a narrow definition and understanding of what makes a person a 'combatant' in fighting forces or groups." I explained in Chapter One that in most cases of DDR, a "combatant" generally refers to the collective of 
privileged and unprivileged combatants who participated in active combat, including armed forces and rebel group members and child soldiers. However, attributing such a narrow definition to the word combatant is illogical in the modern era of warfare since such a small percentage of military personnel actually engage in fighting. For example, in the United States, only 15-20 percent of military personnel actually engage in active combat; the majority serves in backup and logistical roles (Mazurana and Cole 2013). The same can be said for warfare in modern African conflicts where the majority of soldiers serve in auxiliary roles. Therefore, "combatant" for the purposes of DDR needs to be clarified, particularly as it relates to females in their martial versus civilian roles. Once the distinction between combatant and noncombatant is clarified, it needs to be realized in the way DDR practitioners actually approach the disarming and demobilizing of both males and females.

The question then becomes: how are female ex-combatants to be reintegrated if they are blocked from disarming and demobilizing in the first place? Furthermore, what incentive do female ex-combatants have to enter a cantonment site if they know doing so will risk exposure to double standards; sexual harassment; limited job training; and virtually no opportunities to receive job placement once trained? To help answer these questions, my research focuses on exploring possible front-end fixes to DDR policy. If the goal of UN Security Council Resolution 1325 is to see more females reintegrated in post-conflict phases, then more females must be able to easily access cantonment sites for DDR in-processing. Therefore, what can policy practitioners and government leaders do now to fix the design of DDR processes to make cantonment sites more accessible and 
appealing to female ex-combatants? If cantonment is not the answer, what is the best way to ensure that they receive the same benefits as male combatants?

With these questions in mind, I designed a qualitative case study of four African countries - Sierra Leone, Liberia, Burundi, and South Sudan — aimed at understanding when, where, why, and how women are initially blocked from the DDR process. Focusing on the initial planning, staging, and implementing stages of the DDR process, I hope to show how the disarmament and demobilization stages of the DDR process disadvantage female combatants long before they ever attempt reintegration.

\section{Effectiveness, Efficiency, and Equity in DDR Processes}

To examine the DDR process from a gendered perspective, it is useful to think of DDR as a public policy program incorporating a number of useful "tools of public action." According to Salamon and Elliott (2002:19), a tool for public action is "an identifiable method through which collective action is structured to address a public problem." Commonly used tools of public action in public policy are social and economic regulation, vouchers, loans, and government-sponsored programs. In this analysis, the DDR process represents a multi-faceted program that utilizes many different tools, often simultaneously, to promote post-conflict reconstruction and sociopolitical stabilization.

The field of public policy analysis identifies three main criteria for accessing the usefulness of various policy tools and programs: effectiveness, efficiency, and equity. Effectiveness is the first and most basic criterion for gauging the success of a public program. Essentially, effectiveness measures the extent to which an activity achieves its intended objectives. As Salamon and Elliott (2002:23) explain, "Although considerations 
of cost can enter into this judgment, effectiveness judgments are typically made independent of costs." A number of scholars who have attempted to measure the success of DDR programs in Africa raise questions about whether reintegration programs, as currently designed, are effective at all (Humphreys and Weinstein 2007; Pugel 2009). For example, Gilligan et al. (2013) published one of the first quantitative studies providing empirical proof that there are measurable economic programmatic effects to be gained through DDR processes, at least in the case of Burundi. However, these effects were limited only to male ex-combatants who self-selected to enter the DDR program. The authors found no increase in the amount of political or social reintegration for those excombatants who successfully completed DDR. Overlay a gendered perspective and you see that by October 2005 the Burundian government had demobilized 14,000 fighters out of an estimated 85,000; only 3 percent were women (Mazurana and Cole 2013). This means only 420 Burundian women officially participated in DDR. If the estimations calculated by scholars like Lindsey (2000), Puechguirbal (2003), and Coulter et al. (2008) are correct and female combatants may comprise up to 30 percent of fighting forces in Africa, than over 25,000 female ex-combatants remain unaccounted for.

Efficiency is the second measurement. Measuring efficiency involves understanding the balance between costs and benefits. The most efficient program may not be the most effective program. Salamon and Elliott (2002) warn that when it comes to counting costs, we must look at more than just those costs incurred by governments. Unseen costs, like those inflicted on nongovernmental organizations and civilians, while harder to gauge, are also important. For example, in Chapter Four I examine Sierra Leone's decision to design cantonment site intake around a "One Person, One Gun" 
policy, which proved to be effective for quickly demobilizing armed ex-combatants, but it was highly inefficient because it failed to demobilize scores of ex-combatants who served in military capacities without a gun, or with no weapon at all, namely women (Verwimp 2006; Mazurana and Cole 2013; McKay and Mazurana 2004).

The third measure, equity, holds two meanings. First, equity refers to basic fairness, or distributing benefits and costs more or less equally among all those eligible (Salamon and Elliott 2002). In the case of DDR: Are male and female ex-combatants treated equally? Do they have equal access to resources within cantonment sites including basic safety, job training, food, water, shelter? In the second sense, equity refers to "redistribution" or disproportionately channeling benefits to those who lack them. In fact, some scholars argue that "government exists in part to remedy past inequalities and ensure equal opportunity and access to all" (Salamon and Elliott 2002:24). As the passing of Resolution 1325 proved, policy practitioners understand the limitations women face as they attempt to reintegrate after times of violent political conflict and many are beginning to adjust DDR frameworks accordingly (Corbin 2008; Knight and Özerdem 2004; Onyango et al. 2005; Sideris 2003). This leads to what I believe is a third distinction for equity that I first highlighted in Chapter One: inclusion versus consideration. Female concerns cannot merely be considered in the shaping of DDR policies. True equity means that females become active participants in the policy-making process; this is the goal of Resolution 1325. In the following case studies I explore how successful or unsuccessful the various women's rights groups across Africa were in shifting from the margins where they called for considerations, to taking on active roles as recognized, included members to the peacemaking and peacebuilding process. 


\section{Research Design and Methodology}

One of the common mistakes made in qualitative research is selecting cases on the dependent variable (Geddes 1990; King et al. 1994; Johnson and Reynolds 2012). In this project, the dependent variable is the relative success or failure of a DDR process designed to integrate female ex-combatants. It would have been too easy to simply select those cases touted as a success or failure in the African context and work backwards to understand why. However, inductive reasoning of this sort can negatively affect both the internal and external validity of the results for a number of reasons. ${ }^{7}$ First, selecting on the dependent variable can make it difficult to replicate the analysis. Second, the perceived relationship between dependent and independent variables may actually be spurious. According to Johnson and Reynolds (2012), a spurious or false relationship between two variables can sometimes be thought to explain a change in relationship, however they are both actually affected by a third factor. This can be more difficult to see when one works from the vantage point of the dependent variable and searches for independent causes. Third, when research is based on understanding the effects rather than the causes, it may also hinder the overall generalizability of the study (King et al. 1994; Johnson and Reynolds 2012). Therefore, rather than start at the end of the DDR process - as much of the current literature does with its narrow focus on reintegration-I wanted to start at the beginning.

As I first mentioned in Chapter One and again at the beginning of this Chapter, DDR first takes root in the peacemaking arena where the goals and stipulations of the process, including number of cantonment sites, definition of "combatant," and estimated

\footnotetext{
${ }^{7}$ Validity refers to the degree of correspondence between the measures and the concept it is thought to measure (Johnson and Reynolds 2012; King et al. 1994).
} 
intake are codified into the body of peace agreements (Dyfan and Piccirilli 2004; Sjoberg 2010; Schnabel and Tabyshalieva 2012). Therefore, I resolved to select a group of cases of modern African peace agreements and see for myself whether, through an analysis of each case, I could determine the general success or failure of the DDR process in integrating female ex-combatants. Was the initial design of the DDR process conducive to incorporating females? Were cantonment sites segregated by gender? Did females gain equal access to these sites? Evaluating the answers to these and similar questions will prove if each DDR process met the three criteria: effectiveness, efficiency, and equity.

\section{The Peace Accords Matrix: Selecting the Case Studies}

To select the independent variables, I utilized the comparative function of the Peace Accords Matrix (PAM). PAM is a database maintained by the Kroc Institute for International Peace Studies at the University of Notre Dame that catalogs comprehensive peace agreements signed since 1989. According to PAM (2012), a comprehensive peace agreement is defined as "a written document produced through a process of negotiation." It is "comprehensive" in two dimensions: 1) the major parties are involved in the process, and 2) substantive issues underlying the dispute are included in the negotiation process. The database is designed to allow practitioners, researchers, and policymakers access to the full peace accords, providing comparative information on accords and their implementation (PAM 2012).

Utilizing PAM, I constructed a table of all registered peace accords matching four keywords: 1) disarmament, 2) demobilization, 3) reintegration, and 4) women. If the peace accord contains language specific to the keyword, PAM incorporates it into a self- 
generating crosstabulation. I chose these keywords to highlight only those peace accords that specifically address both DDR implementation and women's increased peace and security. According to PAM, thirty-one peace accords contain at least one of the four keywords. These peace agreements range from Angola to Croatia to El Salvador. Of these peace accords, only seven contain all four keywords, including the United Kingdom (1998), Guatemala (1996), and Nepal (2006). Isolating the African cases within the sampling frame, I was left with four peace agreements: Sierra Leone, Burundi, Liberia, and Sudan (See Table 1).

\section{Table 1}

Comparative Table of Sierra Leone, Burundi, Liberia, and Sudan ${ }^{8}$

\begin{tabular}{|l|l|l|l|l|}
\hline Accord Name & \multicolumn{1}{|c|}{$\begin{array}{c}\text { Lomé Peace } \\
\text { Agreement }\end{array}$} & $\begin{array}{c}\text { Arusha Peace } \\
\text { and } \\
\text { Reconciliation } \\
\text { Agreement }\end{array}$ & $\begin{array}{c}\text { Accra Peace } \\
\text { Agreement }\end{array}$ & $\begin{array}{c}\text { Sudan } \\
\text { Comprehensive } \\
\text { Peace } \\
\text { Agreement }\end{array}$ \\
\hline $\begin{array}{l}\text { Violence start } \\
\text { date }\end{array}$ & Sierra Leone & \multicolumn{1}{|c|}{ Burundi } & \multicolumn{1}{c|}{ Liberia } & \multicolumn{1}{|c|}{ Sudan } \\
\hline $\begin{array}{l}\text { Main ceasefire } \\
\text { agreement }\end{array}$ & 18 May 1999 & 16 June 1998 & 01 January 2000 & 16 May 1983 \\
\hline Main accord date & 07 July 1999 & 28 August 2000 & 18 August 2003 & 209 January 2005 \\
\hline $\begin{array}{l}\text { Months of } \\
\text { violence }\end{array}$ & 27 & 66 & 32 & 260 \\
\hline $\begin{array}{l}\text { Number of } \\
\text { deaths }\end{array}$ & 10,000 & 225,000 & 4,058 & 1.2 million \\
\hline $\begin{array}{l}\text { Average deaths } \\
\text { per year }\end{array}$ & 4,445 & 40,909 & 1,521 & 55,400 \\
\hline $\begin{array}{l}\text { Population prior } \\
\text { to conflict }\end{array}$ & $4,009,756$ & $\begin{array}{l}\text { Approx. } \\
6,000,000\end{array}$ & $2,439,389$ & $21,460,587$ \\
\hline $\begin{array}{l}\text { Percent of deaths } \\
\text { of population }\end{array}$ & 0.25 & .05 & 0.17 & 5.59 \\
\hline $\begin{array}{l}\text { Number of } \\
\text { refugees }\end{array}$ & 490,061 & $\begin{array}{l}\text { Between 1 and } \\
1.5 \text { million }\end{array}$ & 33,977 & $\begin{array}{l}693,632 \text { (also } \\
\text { from Darfur })\end{array}$ \\
\hline Number of IDPs & 500,000 & 350,000 & 532,000 & $\begin{array}{l}5,355,000 \text { (also } \\
\text { from Darfur) }\end{array}$ \\
\hline Type of conflict & $\begin{array}{l}\text { Intrastate- } \\
\text { Government }\end{array}$ & $\begin{array}{l}\text { Intrastate- } \\
\text { Government }\end{array}$ & $\begin{array}{l}\text { Intrastate- } \\
\text { Government }\end{array}$ & $\begin{array}{l}\text { Intrastate- } \\
\text { Territory }\end{array}$ \\
\hline
\end{tabular}

\footnotetext{
${ }^{8}$ Peace Accords Matrix. Kroc Institute of International Peace Studies, University of Notre Dame. https://peaceaccords.nd.edu/matrix/matrix/?countries $=17 \&$ countries $=23 \&$ countries $=10 \&$ countriec $=30$. (Accessed 19 October 2013).
} 
Comparing the information in the above columns, it is clear that my case selection is as broad as I could hope to get while still staying true to my purpose of identifying the causal factors inherent in limiting the initial access of female ex-combatants to DDR cantonment sites. These conflicts lasted from two to twenty-two years, with the resulting death tolls ranging from 4,000 to 1.2 million people. Furthermore, the conflicts are geographically disparate, ranging from West to East to South-Central Africa. I have made no attempt to hide my opinion - DDR programs, as they currently operate, do not successfully integrate female ex-combatants. Therefore, allowing for the counterfactual (Johnson and Reynolds 2012; King et al. 1994), if a DDR process were to successfully integrate females, it most likely would have been written into the very fabric of the peace agreement, hence the selection of the keywords and resulting cases.

Within each of the four case studies, I seek to identify a set of possible causal factors that help explain why these DDR processes were successful or not successful at providing women with safe access to cantonment sites for disarmament and demobilization. "Success" is a very difficult term to define as it relates to this project. What can we claim as a notable success? Is it the number of women who pass through the gates of the cantonment site? Or should the emphasis be placed on the overall inclusive design of the process, rather than how many female combatants were actually served? Here I must admit that in true qualitative fashion "success" will be determined by an overall impression of the gendered parity of the DDR process. As Humphreys and Weinstein (2007) explain, given the rudimentary state of knowledge on why certain combatants choose demobilization over others, this examination is, by its very nature, exploratory. Table 2 lists a variety of questions aimed at helping me better understand the 
strengths and weaknesses of the different DDR processes in question, which will help inform my understanding of the success or failure of each program. By analyzing each case study through the lens of effectiveness, efficiency, and equity, I will be able to roughly determine whether the integration of female ex-combatants into the initial DDR process succeeded or failed across the four cases. Those cases that have the most favorable responses to the most questions will be seen as successful while those that do not receive favorable responses will be deemed less successful, maybe even failing.

\section{Table 2}

Measuring Effectiveness, Efficiency, and Equity

\begin{tabular}{|c|c|}
\hline $\begin{array}{l}\text { Effectiveness } \\
\text {-the extent to which an activity } \\
\text { achieves its intended objectives }\end{array}$ & $\begin{array}{l}\text { - Were measures in place to integrate females } \\
\text { into the DDR process? } \\
\text { - How does the DDR policy define combatant? } \\
\text { - What is the status of women in the DDR } \\
\text { policy: dependent or independent? }\end{array}$ \\
\hline $\begin{array}{l}\text { Efficiency } \\
\text {-balance of costs and benefits }\end{array}$ & $\begin{array}{l}\text { - Could women bring their children inside the } \\
\text { - Were there enough cantonment sites to match } \\
\text { the needs of the target population? } \\
\text { - How many women chose self-reintegration } \\
\text { over DDR processing? } \\
\text { - Did sociocultural restrictions inhibit women } \\
\text { from participating? }\end{array}$ \\
\hline $\begin{array}{l}\text { Equity } \\
\text {-basic fairness; redistributing } \\
\text { benefits to those in need }\end{array}$ & $\begin{array}{l}\text { - Were male and female ex-combatants granted } \\
\text { - } \quad \text { Do both genders enjoy equal access to } \\
\text { orientation, healthcare, job training, etc.? } \\
\text { - Were cantonment sites segregated by gender? } \\
\text { - Could women receive additional treatment if } \\
\text { they were the victims of kidnap, rape, or other } \\
\text { sexual torture? }\end{array}$ \\
\hline
\end{tabular}

There are a number of inhibiting factors that must be taken into account for this project, namely the possibility of unreliable and limited data. As King et al. (1994:151) explain, "Since all observation and measurement in the social sciences is imprecise, we are immediately confronted with issues of measurement error." Like selecting on the 
dependent variable, unreliable data may affect the validity of my conclusions. The threat of unreliable data in this project is high. Generally speaking, DDR processes in Africa can be characterized by one word: mismanagement. Cantonment sites keep poor records and rebel organization records are practically nonexistent. Also, governments and NGOs do not often publish data that is aggregated by sex (Knight and Özerdem 2004, Muggah 2007a; Kingma 1007). If officers do produce lists of their soldiers, it is not uncommon for the names of the females to be removed or replaced (Mazurana and Cole 2013; De Watteville 2002; Mazurana 2004 and 2005). Furthermore, what I am interested in examining is why female ex-combatants do not participate in DDR. What possible causal factors inhibit their participation or discourage them from participating? Knowing these factors, government agencies can correct their policies to ameliorate these issues. The inherent problem here is attempting to qualify the lack of something. There is a lack of female ex-combatant participation in DDR programs that I seek to understand. Where are they and why aren't they participating in a manner proportional to males? I must work around these limitations to understand the nature of each DDR program in the African context.

The main method I use to counteract the problem of missing or misleading data is to examine multiple evaluations of the same conflict. For example, for the case of Sierra Leone, I draw on the work of a number of scholars and analysts including Mazurana and Carlson (2004), McKay (2004), Williamson (2006), Mackenzie (2009), Peters and Richards (1998), and Smet (2009). I also analyze the data kept by various international governmental and nongovernmental organizations including UNIFEM, UNICEF, the Center for International Cooperation and Security, the Small Arms Survey, and the 
United States Institute of Peace. This method of examining multiple studies and conducting cross-evaluations will be repeated for Burundi, Liberia, and South Sudan.

\section{Hypotheses: Fixing a Broken System}

The literature review conducted in Chapters One and Two provides a number of important insights into the field of DDR research as it currently stands. The research presented in Chapter Four, DDR in Four African Case Studies, seeks to expand this foundation, utilizing qualitative evidence to promote front-end fixes to what I see as a broken system. While each case of DDR in Africa is unique to the country and the corresponding sociopolitical situation, many common problems have emerged. I outline four main hypotheses directly linked to the issues of effectiveness, efficiency, and equity within DDR processes which result in female ex-combatants choosing "selfreintegration" over participation in a government sanctioned DDR program. Here are the four hypotheses:

$\mathrm{H}_{1} \quad$ When governments define female combatants and noncombatants merely as the "dependents" of men it limits their independent agency and forces them to seek self-reintegration.

$\mathrm{H}_{2} \quad$ Restricting access to cantonment sites to only those excombatants who possess a weapon, namely an AK-47, marginalizes scores of female and male ex-combatants, resulting in self-reintegration.

$\mathrm{H}_{3} \quad$ When DDR practitioners create an environment within cantonment sites whereby females feel threatened with sexual harassment and/or abuse, they will choose self-reintegration.

$\mathrm{H}_{4} \quad$ Providing unequal opportunities for women to receive job training and job placement further marginalizes them from the DDR process, so many turn to self-reintegration. 
Within each case study I will look at these hypotheses to determine which DDR program, if any, does a better job of properly integrating female ex-combatants into the initial DDR process. Furthermore, I will argue that until DDR processes in Africa are able to recognize and proactively combat these four problems, DDR will continue to disproportionately isolate a growing sector of military and paramilitary regimes-female combatants. 


\section{CHAPTER FOUR: DDR IN FOUR AFRICAN CASE STUDIES}

In this Chapter I take each of the four cases-Sierra Leone, Burundi, Liberia, and South Sudan - and examine the ways in which female ex-combatants were integrated into initial DDR processes. I tackle the cases in this order for no other reason than because it is chronological by date of the signing of each respective peace accord. However, by outlining the conflicts chronologically, each case study is able to build upon the other, demonstrating if and how DDR practitioners were able to learn and adapt from proceeding DDR attempts on the continent.

Following a very brief overview of the history of the violence in each country, I summarize the language of the peace accord as it relates to the DDR process. Then I describe how each DDR program was initially outlined, paying specific attention to the role of female ex-combatants. Finally, I evaluate how the DDR process moved from paper into practice to determine whether female ex-combatants truly did receive the care and attention granted to them in the language of the peace accord. Each evaluation will take into account the effectiveness, efficiency, and equity of the DDR process for females who attempted to participate in the program. If the female ex-combatants chose selfreintegration, I explore possible reasons why this was a more favorable option for them than participation in DDR. 


\section{Sierra Leone: One Person, One Gun}

"DDR programmes have consistently failed to attract female combatants... Sierra Leone was no exception."-UNICEF (2005)

In late March 1991, a small group of combatants calling themselves the Revolutionary United Front (RUF), backed by Liberian President Charles Taylor and led by Foday Sankoh, entered Sierra Leone in an attempt to overthrow the government of Major General Joseph Momoh. During his seven-year tenure as president of Sierra Leone (1985-1992), Momoh maintained a corrupt status quo between government and military leaders that led to the virtual collapse of Sierra Leone (Abdullah 2004). Public programming including education, infrastructure, and many economic services came to a halt, forcing anyone wealthy enough to flee Sierra Leone to go in search of a better life (Gberie 2005). By the time the RUF invaded in 1991, Sierra Leone was ranked as one of the poorest countries in the world. In the resulting violent civil war, which lasted eleven years, over 50,000 people were killed and more than 2.5 million people were internally and externally displaced (Bolton 2012; Gberie 2005).

By the end of the first year of fighting, the RUF successfully took over large swaths of Sierra Leone, wresting it from the hands of the Sierra Leone Army (SLA)including a number of alluvial diamond mining operations in the Eastern and Southern districts of Kono and Kenema (Abdullah 2004). While many scholars argue that diamonds were the main motivation and reward for the RUF in instigating the civil war (Auty 1993; Federico 2007; Smillie et al. 2000; Hirsch 2001), they are not the only plentiful resource worth reaping. Sierra Leone is rich in resources, including gold and iron ore and cash crops like coffee and cocoa. In many RUF-controlled areas, large cash 
cropping enterprises were operated using forced labor — often children — throughout the period of fighting (Gberie 2005).

Unable to locate the illusive RUF, which operated using hit-and-run guerilla tactics from the bush, government-trained soldiers in the SLA developed a brutal reputation for indiscriminately targeting anyone they suspected of being in the RUF or an RUF sympathizer. Retaking captured towns the SLA rounded up all survivors and shipped them to concentration camps, which they called "strategic hamlets," in an effort to separate civilians from the insurgents (Gberie 2005). With their growing reputation for brutality, some SLA soldiers discovered that they could earn more money and respect by working with the RUF instead of against them; these soldiers were referred to as "sobels" or "soldiers by day, rebels by night." Abdullah (2004) explains that by 1993, SLA forces began to become indistinguishable from RUF rebels. This led to the creation of the Kamajors, or local militia groups made up of civilian vigilantes designed to protect villages from the SLA and the RUF. However, by the end of the conflict even these groups were grossly corrupt and responsible for mass extortion, torture, killing, and kidnapping (Abdullah 2004; Gberie 2005).

To combat the growing power of the RUF, in 1995 the SLA recruited Executive Outcomes (EO), the South Africa-based mercenary company mentioned in Chapter Two, to assist in pushing the RUF back to the Sierra Leone-Liberian border. Primarily financed through the International Monetary Fund (IMF), the Sierra Leonean government paid EO $\$ 1.8$ million per month for their services (Abdullah 2004; Gberie 2005). With the aid of EO, the SLA was successful and the RUF was forced to retreat, leading to the signing of the first peace agreement, the Abidjan Peace Accord, in November 1996. As part of the 
Accord, a national DDR program was established, which immediately put into motion the disarming of Kamajors and RUF rebels. However, under intense pressure by the United Nations and other international organizations against the use of mercenaries, the Sierra Leonean government was forced to break its contract with EO. Paired with the Kamajors' and the RUF's fear of reprisals or punitive tribunals if they actually began the demobilization process, the fighting recommenced before the ink was dry on the Accord (Keen 2005; Abdullah 2004).

In most reports of the civil war, scholars and analysts are quick to mention how many children were forcibly recruited by the RUF and made to serve as combatants, porters, field hands, diamond miners, and sex workers. While many abductees cooperated with the RUF to save their lives, many more found the mission of the RUF to be worthwhile and joined willingly (Peters and Richard 1998). Conservative estimates place the number of child combatants fighting for the RUF over the eleven year period between 10,000 and 20,000; the average age of each child at the time of their abduction was 7 to 12 years old. However, according to Peters and Richards (1998), estimates of the total number of combatants on all sides of the conflict range from 50,000 to 75,000 . In their study, the average age of approximately half of all combatants was 8 to 14 years old.

By 1999, under intense pressure from the international community, the various parties to the conflict in Sierra Leone agreed to meet again in Lomé, Togo to sign a new commitment to peace and security. Under the auspices of the Economic Community of West African States (ECOWAS), the Lomé Agreement was signed by representatives of the Sierra Leonean government, the Armed Forces Revolutionary Council (AFRC), and the RUF on July 7, 1999. Particular language in the Agreement included an immediate 
ceasefire; the transformation of the RUF into a political party; safeguards for the safety and security of children in accordance with the International Convention on the Rights of the Child; and a renewed commitment to the establishing of the National Commission on Disarmament, Demobilization and Reintegration (NCDDR). Also as part of the Agreement, RUF leader Foday Sankoh and all of his troops were granted complete amnesty for all atrocities committed. Furthermore, Sankoh was granted the position of Vice President of Sierra Leone and made Chairman of the Commission for the Management of Strategic Resources, National Reconstruction, and Development, which oversees all Sierra Leone's diamond mines (Abdullah 2004; Hirsch 2001).

According to Knight (2008), the disarmament, demobilization, and reintegration program (DDRP) designed in the Abidjan Peace Accords and echoed in the Lomé Agreement maintained three specific objectives:

1) Collect, register, disable, and destroy all conventional weapons and munitions retrieved from combatants

2) Demobilize approximately 45,000 ex-combatants of the Armed Forces of Sierra Leone, the RUF, and the Civil Defense Forces (CDF).

3) Prepare and support ex-combatants for reinsertion and socioeconomic reintegration upon discharge from demobilization centers.

Organized under the National Commission for Disarmament, Demobilization, and Reintegration (NCDDR), the process was divided into three phases, the first of which met a disastrous end with the failing of the Abidjan Peace Accords. Phase I witnessed the demobilization of only 1,414 adult combatants before hostilities recommenced in December 1998 (Knight 2008; World Bank 2002; NCDDRC 2002). Phase II began immediately after the signing of the Lomé Agreement in July 1999, supervised by the UN 
Observer Mission in Sierra Leone (UNOMSIL). However, this phase was also stalled due to an increase in hostilities, including the hostage-taking of $500 \mathrm{UN}$ observers by the RUF in May 2000. Combatants involved in an attack on a cantonment explained:

The ex-combatants in the [demobilization] camp would get together and plan...We would take drugs and then go as a group to physically attack the DDR programmers for not giving us our money. We were very angry about not getting our money (Denov 2009:25; Denov and Maclure 2005).

Phase III began in May 2001 after the signing of another ceasefire agreement. During this phase the United Nations increased its presence in Sierra Leone to 17,5000 troops (making it the largest UN mission in history at the time). According to Knight (2008), over the combined three phases, 72,500 combatants were disarmed by the United Nations Mission in Sierra Leone (UNAMSIL) at over seventy five cantonment sites, including 37,000 CDF, 24,000 RUF, and 11,500 SLA (Anderlini and Mazurana 2004). Of those disarmed, 95 percent were also demobilized, 81 percent registered for training under the demobilization process, and 80 percent received transitional subsistent allowance (TSA). A further 2,600 combatants were reintegrated into the new national army through the Military Reintegration Programme (MRP).

Up to this point my analysis of the DDR process in Sierra Leone has been genderless, with no mention of males or females as the primary combatants. According to Mackenzie (2009), while the exact number of female combatants fighting in Sierra Leone on all sides of the conflict remains unknown, estimates range from 10 percent to upwards of 50 percent. Furthermore, it is estimated that of the children recruited into the RUF, girls represented at least 30 percent (Mazurana and Carlson 2004; Friedman-Rudovsky 2013; McKay and Mazurana 2004). Many females were responsible for using small arms 
during the conflict. One girl in the RUF explained: "I was eager to become a soldier and have my own gun so that I would be able to resist threats and harassment from other soldiers" (Denov 2009:13). Another girl said: "I felt power when I had a gun. As long as you are holding a gun, you have power over those who don't. It gave me more status and power" (Denov 2009:13).

If females were so actively involved in the violence during the civil war as active combatants, surely there were provisions in place for them in the body of the Lomé Agreement. After all, Sierra Leone was specifically selected as a case study in this project because the peace accord mentioned "women." Unfortunately, within the body of the Lomé Agreement (which is a 28-page document) the word "women" is only mentioned once. Article XXVIII Section 2 states:

Given that women have been particularly victimized during the war, special attention shall be accorded to their needs and potentials in formulating and implementing national rehabilitation, reconstruction and development programmes, to enable them to play a central role in the moral, social and physical reconstruction of Sierra Leone (PAM 2012).

The "special attention" mentioned in Article XXVIII Section 2 relates to addressing the overwhelming number of human rights abuses inflicted on females during the civil war. As a result of this narrow focus on women's victimization, most gendered research on Sierra Leonean civil war examines the extent of sexual violence inflicted by women and on women. For example, the Women's Commission for Refugee Woman and Children (2002) discovered that most girls in Sierra Leone thought that sexual violence was inevitable for them. In a 2002 survey, Physicians for Human Rights calculated that as many as 215,000 to 257,000 Sierra Leonean females may have been subjected to sexual 
violence $^{9}$ during the conflict (Denov 2006). In a random selection of 733 females surveyed in 2000 by the United Nations, of whom 20 percent were girls between the ages of 6 and 17-years-old, 73 percent reported having experienced human rights abuses; 52 percent said they were subjected to sexual violence; 47 percent reported being raped; and 26 percent reported being gang raped (UNICEF 2005). Slightly less than half of the respondents (41 percent) were abducted and approximately 3 percent of those taken were forced to marry their abductor (United Nations 2001; UNICEF 2005). In some Districts, like Bombali and Kono, the number of young females abducted by the RUF reached between 60 and 90 percent (UNICEF 2005). Furthermore, Cohen's (2013) surveys and interviews with Sierra Leonean female ex-combatants, found that one in four reported incidents of gang rape were perpetrated by female combatants.

This last figure shows that women in Sierra Leone were not merely victims of sexual violence. They were also combatants, soldiers in need of access to DDR. Unfortunately, during the three phases of DDR in Sierra Leone, of the roughly 75,000 adult combatants disarmed, less than 5,000, or 6.5 percent, were females (Mackenzie 2009; Mazurana and Carlson 2004; Coulter et al. 2008). When it comes to the disarming and demobilizing of children, out of the 6,845 disarmed, only 8 percent were girls. So where were the female ex-combatants in the Sierra Leone DDR process? According to scholars like McKay (2004), Mackenzie (2009), and Mazurana and Carlson (2004), female combatants did not participate in the DDR process for a number of reasons. First, relatively few female ex-combatants were demobilized because of a genderdiscriminatory framework which saw girls only as sex slaves, wives, and camp followers

\footnotetext{
${ }^{9}$ In their study, "sexual violence" referred to the overarching term used to describe "any violence, physical or psychological, carried out through sexual means or by targeting sexuality" (Denov 2006:320).
} 
(McKay 2004; Mackenzie 2009). As McKay and Mazurana (2004) explain, since the DDR process was planned and implemented by military officials, they focused entirely too much attention on "men with guns," at the expense of those whom militaries do not consider to be "real soldiers," i.e. females, particularly girls. While it is certainly true that a large number of women were forcibly abducted by the RUF and did not serve as combatants, the decision to label all females as "camp followers" demonstrates reluctance on the part of reintegration agencies to properly identify those women who actually chose to fight as combatants (Mackenzie 2009; McKay and Mazurana 2004). In her interviews with female ex-combatants in 2005, Mackenzie (2009) found that most women were all too eager to associate themselves as soldiers, quickly pointing out which armed groups they participated in, what rank they held, and the roles they carried out. Over 75 percent of women interviewed declared that they were involved in active combat duties. One woman even reported that at least 100 women fought in her group and that they all carried guns (Mackenzie 2009).

However, this leads us to the second access barrier: not all female combatants maintained access to a gun during the conflict (Coulter 2004; Mazurana and Carlson 2004; Coulter et al. 2008). According to UNICEF (2005), while more than half of the young female ex-combatants incorporated into the 2003 Girls Left Behind project ${ }^{10}$ said they wanted to participate in DDR, they lacked the weapons or ammunition that had to be turned in before they could access the cantonment sites, effectively blocking them from participating. As I explained in Chapters One and Two, women often leave their guns

\footnotetext{
${ }^{10}$ The Girls Left Behind project was established in 2004 after a successful 2003 initiative was able to identify and assist over 3,000 girls who were not included in the original DDR process. From the 2003 cohort, of the 724 girls registered 110 were reunited with families and 460 enrolled in skills training and/or other income generating activities (UNICEF 2005).
} 
behind when fleeing armed groups. Others have their guns deliberately taken away so that they cannot participate. Still more female combatants are simply never in possession of a weapon (De Watteville 2002; Mazurana and Cole 2013; Mackenzie 2009). For female ex-combatants in Sierra Leone who escaped from armed groups before attempting disarmament and demobilization, they felt they were not eligible because they were no longer linked with the group; in a way, these women no longer recognized themselves as combatants (Mackenzie 2009).

The requirement to present a firearm at disarmament locations during the initial phases of DDR was reflected in the NCDRR's policy of "One Person, One Gun," which restricted access to cantonment sites to only those soldiers in possession of a gun, namely an AK-47 assault rifle (Mazurana and Cole 2013). At registration sites across the country, combatants were required to answer a series of questions to determine whether they really were combatants; they also had to demonstrate their skill with an AK-47 by properly dismantling it and putting it back together (Mazurana and Cole 2013). While boys and girls under the age of 18 -years-old were exempt from this rule due to their status as children, most did not know this. ${ }^{11}$ Furthermore, the rule was unevenly applied across registration sites causing a number of children, particularly girls, to be turned away (McKay and Mazurana 2004; UNICEF 2005).

Finally, McKay and Mazurana (2004) argue that the set-up of the DDR cantonments in Sierra Leone into centrally-located sites discouraged female enrolment for three reasons: 1) the public nature of the cantonments, 2) insecurity and violence at DDR sites, and 3) lack of proper medical and hygienic facilities. Furthermore, many

\footnotetext{
${ }^{11}$ According to DDR procedures, child combatants were supposed to be eligible for demobilization if they were between 7 and 17-years-old; had learned to "cock and load" a gun; received any type of military training; and had spent 6 months or above in the fighting forces (Mackenzie 2009; UNICEF 2005).
} 
female ex-combatants who witnessed the disastrous first phase of DDR were reluctant to participate because they didn't see how the process was actually helping people to reintegrate. Some women referred to the "flamboyant promises" made to ex-combatants under the first phase, which were not fulfilled when the program fell apart (Mackenzie 2009). Due to their limited status as "camp followers" and "sex slaves," females who accessed cantonment sites were not viewed as appropriate recipients of full DDR benefits including skills training and education (McKay and Mazurana 2004; McKay 2004). One RUF soldier described the process thus:

DDR was not organized, unreliable, and biased. [Officers] slotted their relations who were not combatants, into the program. These were the people that were benefitting so much. DDR would go on the radio and make announcement that ex-combatants should go for their allowances the following day, but by the time you get there, they have changed (Denov 2009:19).

Finally, many female ex-combatants chose self-reintegration over DDR for a very personal and powerful reason - fear. Of those active in the Girls Left Behind project, over 75 percent of young female ex-combatants, when asked why they did not participate, argued that fear of being arrested, executed, or shamed by their families and communities kept them from participating in DDR. Many female ex-combatants interviewed by Mackenzie (2009) expressed similar fears, including fear of retaliation from community members and other rebel groups. Of those who wanted to participate, it was fear of the insecurity within cantonments that kept them at bay; a number of females expressed the opinion that if the cantonments were segregated by sex they would have participated (UNICEF 2005). For some women, it was the fear felt by their families that kept them from participating. In particular, fathers and husbands frequently blocked 
female ex-combatants from participating in DDR because of the possible stigmatization or shame that could connect back to the family (Mackenzie 2009).

All four of these arguments point to a largely overlooked distinction made for why women chose self-reintegration in Sierra Leone: it's not that female ex-combatants felt "left out" of DDR, rather, many chose to avoid it because they recognized problems with the way it was implemented (Mackenzie 2009). For other women, the reasons for avoiding the DDR process are even more interesting. Mackenzie (2009) interviewed a number of women who hinted at the idea that participating in DDR was somehow "beneath them," whether it was because they would be mingling with soldiers of lower rank, or because they saw the DDR process as stripping them of their command and respect. Still more women did not participate because they simply had other objectives at the time, like finding their families or accepting mercenary positions in a neighboring conflict (Mackenzie 2009).

Returning to my measures of effectiveness, efficiency, and equity in the DDR process, how should we evaluate Sierra Leone? First, was the DDR process effective in integrating female ex-combatants into the disarmament and demobilization stages? No. There were no measures put into place to encourage females to participate; in fact the opposite is true. While a percentage of female ex-combatants seemed to have chosen selfreintegration, countless more were blocked from the process through restrictive policy definitions, corrupt military commanders, and unreasonable disarmament requirements. Second, was the DDR process in Sierra Leone efficiently able to process female excombatants through cantonment sites? No. Women's needs were not met within cantonments, including limited or no access to basic sanitation and hygiene. Furthermore, 
because of the stigma attached to the DDR process as a corrupt and unhelpful enterprise, the majority of women chose self-reintegration. Finally, did the DDR process in Sierra Leone provide equal opportunities for all DDR benefits between male and female combatants? No. Males were disproportionately targeted to receive all DDR benefits, including healthcare, job training, education, even reinsertion money. Furthermore, the cantonment sites were not segregated by gender, causing women to disproportionately feel targeted by violence and insecurity at the hands of the male combatants.

What about my hypotheses regarding reasons why female ex-combatants would choose self-reintegration over the DDR process? In the case of Sierra Leone, all four hypotheses are upheld. The NCDDR's labeling of female combatants merely as "camp followers" and "sex slaves" limited their independent agency and encouraged them to seek self-reintegration. Also, by restricting access to cantonment sites to those in possession of an AK-47, scores of female combatants who did not carry a gun were forced to self-reintegrate. Furthermore, the design of the cantonment sites left female combatants feeling threatened and unsafe, so they chose not to enter. Finally, for those female combatants who entered the DDR process, the opportunities presented to them were unequal compared to men, with the focus being on the women going "back to normal." Based on these assertions, I can only conclude that the DDR process in Sierra Leone utterly failed to assist in the disarming and demobilization of the female excombatants who were active in its decade-long civil war. 


\section{Burundi: Prostitutes and Thieves}

"Women combatants, we used to say they were prostitutes and thieves. We saw them as animals." — civilian interviewed by the World Bank (2013)

While the case study on Sierra Leone focused explicitly on the period of violence immediately pertinent to the signing of the Lomé Agreement, an analysis of the conflict in Burundi is more complicated to succinctly craft, with long-standing ethnic and sociocultural issues spanning decades, culminating in what scholars have argued are two events of genocide separated by almost twenty years of history. I do my best in this case study to provide an overview of the historical tension between the Hutus and Tutsis that is brief, yet informative enough for me to produce a knowledgeable analysis of the peace process and resulting DDR program. ${ }^{12}$

For the past several decades, frequent conflicts between Hutus and Tutsis in the Great Lakes region have caused a series of ethnic migrations between Rwanda and Burundi, routinely involving neighboring countries including Uganda, Tanzania, and the DRC (Mwakikagile 2012; Lemarchand 2009). Within Burundi, political violence and ethnic conflict between the Hutus majority and the Tutsis dates back to well before the early 1960s, when the country was still a colony controlled by Belgium (Knight 2008). From independence until 1966, Burundi was ruled by a constitutional monarchy. Tensions were high between supporters of the Hutu king, Mwami Mwambutsa IV, and the Prime Minister, which rotated between Hutus and Tutsis through assassinations and corruption. This tension caused frequent bloodletting by the different ethnic groups. For example, in 1959 Rwandan Hutus massacred Tutsis by the thousands, forcing thousands more to flee to Burundi (Knight 2008).

\footnotetext{
${ }^{12}$ For an expanded look at the history of Burundi, I recommend Peter Uvin's (1999) Life after Violence: A People's Story of Burundi and René Lemarchand's (1996) Burundi: Ethnic Conflict and Genocide.
} 
By 1966, Tutsi Prime Minister Captain Michel Micombero deposed the king's son, Prince Ntare V, and established Burundi as a military dictatorship. In 1972, conflict within Burundi intensified when a group of Hutus from the Burundi Workers' Party (UBU) organized and carried out systematic attacks on Tutsis. The Tutsi military reprisals for these attacks were immediate, exhaustive, and brutal, leading many to classify the event as genocide since the violence was systematic and aimed at wiping out the ethnic group in its entirety (Lemarchand 1974, 1996; Bowen 1973).

The 1990s was the worst decade of fighting in this small country of approximately 6 million people. In October 1993, after twenty years of military rule, the first democratically elected Hutu President, Melchior Ndadaye, as well as the president and vice president of the National Assembly, were assassinated by Tutsi extremists (Uvin 2009). Across Burundi, Hutu peasants responded violently, killing between 50,000 to 100,000 Tutsis over the span of one year. In brutal acts of reprisal, the Tutsi military rounded up thousands of Hutus, systematically killing them (Totten et al. 2004; Longman 1998). In a 1996 report, the UN Security Council concluded that the death of Ndadaye and the resulting violence represented "acts of genocide" against the Tutsi minority.

The conflict in Burundi reached new levels in April 1994 when a plane carrying Ndadaye's successor, Cyprien Ntaryamira, and Rwandan President Juvenal Habyarimana was shot down by Tutsi extremists. Violence erupted immediately in the streets of Kigali as Rwanda descended into its own genocide. In Burundi, the death of Ntaryamira and the sociopolitical instability caused by hundreds of thousands Rwandans fleeing into the country resulted in years of violence and conflict. Conservative estimates place the death toll since 1993 at over 300,000 people, while over 350,000 people were internally 
displaced and well over 1 million Burundians were externally displaced into neighboring countries in the region (Knight 2008; Lemarchand 1996). According to statistics from 2006, 52 percent of all Burundians fled their homes at least once during the war (Uvin 2009). Ultimately, almost a quarter of the entire population of Burundi was uprooted (United Nations 2005).

Between 1997 and 1999, regional and international actors, including the UN, UNICEF, the World Bank, and the Organization of African Union (OAU) — now the African Union (AU) - met with Hutu and Tutsi representatives to negotiate an end to the violence. The resulting peace agreement, the Arusha Peace and Reconciliation Agreement, was signed in 2000 in Arusha, Tanzania. Apart from granting partial amnesty to the rebels, the agreement outlined specific arrangements for the establishing a National Army and for the implementation of a DDR process (Knight 2008; PAM 2012). Unfortunately, since not all the warring parties signed the Agreement, the UN and the OAU struggled to create the needed security environment for the DDR process to be properly implemented. However, by 2003 the National Programme for DDR (PNDDR) was initiated with the objective to disarm 55,000 ex-combatants, including 8,000 child soldiers (United Nations 2005).

Estimates place the total number of combatants fighting on all sides of the conflict at roughly 85,000 for men and women (Mazurana and Cole 2013). The number of expected child soldiers may seem high, but an astounding 73 percent of the population in Burundi is below 30 years of age; 46 percent of the population is below 15 years old (Uvin 2009). With such a young population, children and youths were naturally deeply involved in all aspects of the conflict. Operating in a tense sociopolitical environment 
where all sides were plagued by mutual mistrust, by 2005 the PNDDR was able to disarm and demobilize between 10,000 to 15,000 ex-combatants, including 2,700 child soldiers, at 11 cantonment site locations spread around the country (Mazurana and Cole 2013; United Nations 2005; Alusala 2005).

One of the major problems with implementing the DDR process in Burundi was that the various rebel organizations provided inaccurate numbers of their forces, leading to confusion and frustration on the part of the PNDDR organizers (Knight 2008; United Nations 2005). Another problem was that many combatants arrived for demobilization and simply refused to disarm, stalling the process and causing insecurity at the cantonment sites (Knight 2008). Living in pre-disarmament assembly areas (PDAAs) spaced around the country, many armed combatants were beginning the demobilization process before proper disarming facilities could be established; they used their weapons to guard against intruders as the peacekeeping forces had no mandate in place to provide the combatants with protection (Frey and Boshoff 2005; Alusala 2005). Organized into 10-15 man groups, the combatants were met once a week by peacekeepers who delivered food rations.

Once the demobilization sites were operational, different rebel groups allowed soldiers to slowly trickle into the DDR facilities, sometimes at a rate of less than 150 combatants per week (Alusala 2005). However, life within the PDAAs and in the cantonments themselves was dangerous and many combatants-hungry, discouraged, and tired of waiting - deserted the program. Cantonments and refugee camps suffered from a lack of proper shelter and clean and sufficient water and latrines. New cantonments and refugee camps were quickly contaminated by human waste, increasing the risk health 
problems like cholera, dysentery, diarrhea, and measles (Kadende-Kaiser 2012).

Furthermore, a combination of poor harvests, active landmines, and continuing insecurity in the countryside made food security within refugee camps and cantonments unachievable (Smith 1999; Kadende-Kaiser 2012). ${ }^{13}$ Within the camps, problems over rank disputes and disharmony amongst combatants made conditions even more tense (Frey and Boshoff 2005). In 2005, recognizing the deplorable conditions within the cantonment sites, some rebel organizations, like the FNL (National Forces of Liberation), vowed not to send any more combatants until conditions improved (Alusala 2005).

The disarmament phase of the DDR process in Burundi contained an interesting caveat aimed at removing as many SALW as possible, including those held by civilians. The transitional government created a special fund designed to support an arms collection program for civilians. It was intended to be a voluntary program where those civilians who wanted to keep their arms could register and obtain permits so the government could record who had weapons and why (Alusala 2005). In this way, the registering of permits allowed those families that needed a weapon for protection or hunting, like a basic rifle, to keep it, but they had to be willing to register it with local government authorities. They also had to justify why the weapon was necessary, in this way the government could round up weapons like AK-47s, rockets, and mines from communities.

Ex-combatants who were successfully disarmed and demobilized were eligible for a variety of reintegration benefit options. By 2007, 96 percent of ex-combatants chose to receive income-generating activity benefits; 3.6 percent chose vocational training; and less than 1 percent chose to resume formal education (MDRP 2007; Gilligan et al. 2012).

\footnotetext{
${ }^{13}$ Aside from basic human security concerns within Burundian refugee camps, only 25 percent of the camps were accessible by roads; in the rainy season, these camps were virtually cut off from the rest of the country (Smith 1999).
} 
Ex-combatants were also eligible to receive reinsertion allowances totaling 18 months of wages; half of this allowance was paid upon leaving the cantonment and the rest was allotted to the ex-combatants over a series of three installments (United Nations 2005). According to the United Nations, as well as a number of scholars and policy analysts, the various setbacks notwithstanding, the DDR process in Burundi was labeled a success, with 21,379 total ex-combatants disarmed and demobilized (Uvin 2009; Frey and Boshoff 2005; Alusala 2005). ${ }^{14}$

So how did female combatants fare during the peacemaking and DDR process in Burundi? Unlike the situation for women in Sierra Leone, the women of Burundi played a major role in the shaping of the peace. This is evident in the language of the Arusha Peace and Reconciliation Agreement, which pays frequent and specific attention to the plight and special interests of women, children, and the disabled. Women fought for over five years to gain equal participation in the Arusha peace talks, which they were denied to the end. Instead, female activists, through the assistance of the UN Development Fund for Women (UNIFEM), were able to secure a position in Arusha as "observers" of the peace talks (Kadende-Kaiser 2012). The Agreement was finally signed on 29 August 2000, a mere two months before the UN Security Council adopted Resolution 1325. In a very real way, after the adoption of Resolution 1325, the peacebuilding process in Burundi became an arena for the international community to watch as a country recovering from a decade of violence attempted to incorporate women into peacemaking and peacebuilding.

While in Arusha women could only observe, back in Burundi they were active participants in the peace process. Kadende-Kaiser (2012) argues that throughout the

\footnotetext{
${ }^{14}$ Other sources claim that upwards of 55,000 ex-combatants were demobilized over the multi-year process (Edmonds et al. 2009; Uvin 2009).
} 
conflict women assumed major leadership roles in their communities by organizing the return of displaced neighbors, encouraging their men to participate in the peace talks, and bringing international attention to the importance of power sharing between all key political actors, as well as between men and women, through media and international mediators like UNIFEM. A number of women's organizations worked to promote better care and treatment of widows, orphans, and at-risk youth, irrespective of their ethnic background. Various organizations hosted fundraisers for items like food, blankets, and clothing; worked to rebuild schools and homes; and built centers devoted to aiding females who were subjected to trauma and sexual violence.

Unfortunately, while many women across Burundi worked hard to promote peace and security, thousands more were active combatants, instigating further violence, even after the signing of the 2000 Agreement. Exact estimates of female participation are very difficult to gauge, but whether through forced recruitment or voluntary participation, females made up around 30 percent of fighting forces, both military and paramilitary (Mazurana and Cole 2013). One female commander of the National Council for the Defense of Democracy/Forces of Defense of Democracy (CNDD-FDD) described her reason for joining the Hutu insurgent force:

I had voted for the president that was killed after his victory...I was staying in Burundi, but ran away with my husband and my baby after the destruction of our house [by army forces]. Fifteen of my relatives were killed. The army was following us. There was a massacre in the village in which we were hiding and we decided we could not stay there. In 1996, I took the decision to join the armed group (Mazurana 2013:150). 
This is the story of many Burundian females. Tired of being victims, they took up arms with rebels and the military as a way to protect themselves and their families. Another female combatant, Emiline Manirambona, explains:

The reason I went to war is because people would come around, hurt you, sometimes kill you, or they would rape you. People in armed groups would do these things. So I decided to maybe die fighting...instead of being tortured at home (World Bank 2013).

For other women, working with the rebels was not a choice. If you did not aid them, you were killed immediately. Annabelle Nshimirimana, 20, supplied the FNL (Forces Nationales de Liberation) with food and firewood, portering goods through the mountains at night to avoid detection from the military and other community members. She had to preserve the secret of the FNL hiding places or risk retaliation. Nshimirimana's neighbor, Odile Nibizi, a young mother of six, answered her door late one night to find FNL soldiers asking for food and shelter. Fearing for her life, and the lives of her children, she took them in and cared for them; the FNL soldiers stayed with her for an entire year, which led to her financial ruin and the loss of the family business (IRIN 2010). Virtually all the stories told by female combatants—active or not—contain the same message: "there was no way out - you either killed or you were killed" (IRIN 2010).

For Burundian women, the decade-long conflict proved devastating to health and human security. Rape, sexual violence, and torture were widespread throughout the entirety of the conflict, with a 2007 Amnesty International report arguing that, between 2004 and 2006, an average of 25 women per week were raped (Kadende-Kaiser 2012). HIV, STIs, and other infections were rampant throughout communities and militia groups. Furthermore, women combatants were feared and reviled by most in the civilian community and distrusted for taking on masculine roles during the fighting (World Bank 
2013). This encouraged many women to forgo the DDR process in order to try to more seamlessly transition back into civilian life.

While women were active in ensuring their recommendations were incorporated into the framework of the Arusha Peace and Reconciliation Agreement, the NCDDR procedure document, created to outline how the DDR process would proceed, was vague and non-inclusive of issues concerning female soldiers (World Bank 2013; Alusala 2005). All the document said was that the DDR program:

Will give women soldiers special attention related to their specific needs, such as security (by housing them separately from men in demobilization centers) and hygiene, and [offer] them social-economic support that will allow them to reintegrate into society (Alusala 2005).

However, the type and amount of support granted to women soldiers was left unspecified. Addressing the needs of child soldiers was similarly vague, with brief mention made to the sharing of responsibilities between the NCDDR and UNICEF (Alusala 2005). While no official figures are posted on women's involvement in the war or in DDR, of the nearly 22,000 ex-combatants disarmed and demobilized in Burundi, approximately 3,015 were women; only 494 were children (Knight 2008). When you consider that upwards of 30 percent of Burundian armed forces and rebel groups were potentially females, the lack of participation of female ex-combatants in DDR is certainly troubling (Mazurana and Cole 2013).

Like in Sierra Leone, women combatants in Burundi did not participate in DDR for a number of reasons including: lack of "combatant" status, fear of insecurity within cantonments, and fear of reprisals from community members for continuing to identify as a soldier. The World Bank (2013) explains that, while being a woman in Burundi is already a disadvantage for socioeconomic stability, female ex-combatants are 
additionally stigmatized. Their intersectional identity as ex-combatants and women makes finding work virtually impossible because they are feared and marginalized. In an interview for the World Bank (2013), ex-combatant Clemance Ntamatinyiro explained, “Some people said, 'you've been fighting in the war. Don't come near us.' They thought that because of what I learned in the war that I had bad intentions."

While most women combatants did not participate in DDR, the few that did found that the program did not meet their expectations. In Chapter Two I provided the summary given by a female officer who lamented the inefficient DDR process, arguing that living conditions within the cantonments were very poor, especially for women. This female officer cited issues with malnutrition, a lack of access to female clothing, and limited to no access to toiletries and feminine hygiene supplies (Mazurana 2004). Furthermore, the NCDDR practitioners made promises to the women combatants that, over time, they did not keep. The same senior commander argued, "The progress of the DDR process is doubtful, it is not moving forward as expected...As time goes by, women and girls are feeling they have been abandoned" (Mazurana 2004:63). Based on the results females gained in promoting women's equality in the drafting of the Arusha Peace and Reconciliation Agreement, many Burundian women's organizations expected that female ex-combatants would have the opportunity to integrate into the police and military, like many young men did. This did not happen; instead, female combatants were pressured to return to civilian life rather than continue in their militarized roles (Mazurana 2004; Mazurana and Cole 2013).

Based on this analysis, let's summarize the effectiveness, efficiency, and equity of the DDR process in Burundi for female ex-combatants. First, was the DDR process in 
Burundi effective in integrating female ex-combatants into the disarmament and demobilization stages? No. While women made impressive gains in shaping the Arusha Peace and Reconciliation Agreement to pay specific attention to the rights and needs of women, the language pertaining to women combatants in DDR remained vague. Females did not feel encouraged to participate so very few presented themselves at cantonment sites. Second, was the DDR process efficiently able to process female ex-combatants through cantonment sites? No. Like in Sierra Leone, women's needs were not met within cantonments, to include basic sanitation and hygiene requirements. Most female excombatants felt that the DDR process did not meet their expectations and avoided it. The meager number of women who officially completed the DDR process is deplorable compared to the number of known active female combatants.

Finally, did DDR in Burundi provide equal opportunities for all benefits between male and female combatants? Here I am tempted to respond with a noncommittal, unscholarly response: kind of. First, whether or not it was implemented at all the cantonment sites, the language of the NCDDR procedure document outlined the specific needs of women within cantonments, including housing them separately from men (Alusala 2005). This represents a departure from Sierra Leone's peace agreement, which made no mention of women's specific needs during DDR. Even though the conditions within cantonments were deplorable and women actively avoided it for this reason, at least the intent was there to provide them a safe and secure environment. Furthermore, while it is true that males were disproportionately targeted to receive all demobilization benefits, a number of initiatives were designed to provide women with specific opportunities for increased socioeconomic reintegration (Gilligan et al. 2013; World 
Bank 2013; Alusala 2005; Frey and Boshoff 2005). A number of Burundian women's organizations have developed demobilizing and reintegration programs for female combatants, focusing on teaching marketable skills and providing psychological support and counseling (World Bank 2013). While conditions are far from equal, at least compared to Sierra Leone, I feel compelled to give the Burundi DDR process a better "equity" score.

In the case of Burundi, all four of my hypotheses regarding self-reintegration are upheld. Women combatants were unsure of their combat status, which kept them from the process, and officers frequently removed the names of females in their group. For those women unsure of their combatant status, and those who were not active fighters felt they were not supposed to participate in the DDR process. For those who did qualify for DDR, the deplorable conditions within cantonments kept many from participating. Finally, many felt that, even though they made gains in the peace process, a number of recommendations were not accepted, including women's equal access to education and land rights. Furthermore, many female combatants who were expecting to be able to integrate into the military were some of the first to be disarmed and demobilized. I conclude that, while the Burundi DDR process was able to improve in certain areas from Sierra Leone, it was still poorly managed and very few women received any tangible benefits. 


\section{Liberia: Dangerous Disconnect}

"There has been a 'dangerous connect' between disarmament and reintegration in Liberia.”-_Jennings (2007)

It has been over ten years, but the small West African country of Liberia is still recovering socially and economically from nearly two decades of violent political conflict. The violence began in 1989 with the overthrown of Samuel Doe by Charles Taylor and the National Patriotic Front of Liberia (NPFL). By the end of the first wave of conflict in 1996, now called the First Liberian Civil War, over 200,000 people were killed and hundreds of thousands more displaced. With a population of roughly 2 million people, the first war alone claimed over 8 percent of Liberia's people (Sesay 1996). The NPFL and other rebel groups like the Armed Forces of Liberia (AFL) lacked discipline and used violence and terror to victimize civilians. The AFL's scorched earth policy and the NPFL's blatant use of children as mine detectors and soldiers resulted in massive death and displacement. Civilians accounted for over 90 percent of the deaths in 1990 alone (Riley and Sesay 1996; AFELL 1998).

The atrocities committed on women by the AFL and the NPFL during the First Liberian Civil War are almost beyond words. In a 1995 study, 33 percent of women claimed to have been raped during the conflict while a further 18 percent reported witnessing the rape of their relatives or companions; most victims were between 10 and 36 years old. Of those raped, at least 6 percent became pregnant (AFELL 1998; Harris 1995). However, the sexual abuse and torture of women extended well beyond rape. Women who were suspected of being linked to rebel groups were routinely detained, beaten, tied up, and strip searched (Swiss et al. 1996). They were forced to watch as their children or friends were lined up in front of them and shot. If they did not applaud or 
laugh as the soldiers did this the gun was turned on them. Pregnant women were routinely held down to have their bellies cut open and their babies removed to be cut into pieces. The soldiers required audiences of community members to watch and applaud as they cut the women open, often taking bets on the sex of the baby (Swiss 1991; AFELL 1998).

After nine successive peace agreements signed from 1990 to 1994 failed to end the violence, the parties signed the Abuja Agreement in August 1995. However, this peace agreement and the resulting ceasefire also failed to staunch the flow of violence. By April 1999, new rebel organizations including the Liberians United for Reconciliation and Democracy (LURD) and the Movement for Democracy in Liberia staged an insurgency against Charles Taylor's government. In April 2003, Taylor controlled less than one third of Liberia. Monrovia, the capital, was sieged by the LURD, killing at least 1,000 civilians and displacing thousands more. In an attempt to stabilize Monrovia and protect the U.S. embassy and its staff there, the U.S. established the Joint Task Force Liberia in July 2003, which authorized the sending of a small contingency of U.S. troops into Monrovia to push the LURD out. By the end of July the LURD declared a ceasefire and agreed to meet Taylor and the other rebel leaders at the peace talks in Accra, Ghana which had been quietly taking place since June (Jaye 2003; The Guardian 2003). During the Second Liberian Civil War between 150,000 and 300,000 people died and hundreds of thousands were once again displaced. This means that between the First and the Second Liberian Civil Wars, this small country saw an almost 20 percent decrease in the size of the population.

The Accra Comprehensive Peace Agreement (CPA) was signed on August 18, 2003. It called for the immediate removal of Charles Taylor, who was exiled to Nigeria 
and the establishing of a transitional government that would work to secure the country until elections could be held. The U.S. troops, assisted by ECOMIL (the ECOWAS Mission in Liberia) and Nigerian-led West African forces secured Monrovia and began the slow process of rebuilding peace and stability in the country. Under the auspices of the National Commission on Disarmament, Demobilization, Rehabilitation and Reintegration (NCDDRR), the DDR process began in December 2003, a few short months after the signing of the CPA. It was a complete disaster; the security situation surrounding the only functioning cantonment site was not adequately explored, which left combatants interested in disarming and demobilizing at risk (Jennings 2008). When the combatants were told they would not receive an immediate cash payment upon turning over their weapons, deadly rioting ensued; at least nine people died (Jennings 2007). The DDR process was shut down and did not resume again until April 2004. Once it resumed, the NCDDRR was able to proceed in a relative calm until the disarmament and demobilization phases were officially completed in November 2004 (Nichols 2005).

The disarming phase started slow because of the entry requirement to present a weapon. This did not affect fighters under 18 years old, because children could be demobilized without weapons. However, for those combatants over 18 years old, the rule was strictly enforced. The problem was that virtually no combatants were able to present a weapon, particularly females who were categorized simply as "camp followers" (Jennings 2007; Coulter et al. 2008). Therefore, during the December-April interlude, the requirement was changed to only 150 rounds of ammunition. While the number of weapons collected drastically reduced, there was an explosion in the number of combatants eager to participate in the DDR process. Jennings (2008) explains that by 
November 2004, over 100,000 combatants were registered and disarmed; this figure is radical considering that the early estimates of how many combatants would participate were set in the 38,000 to 45,000 range. However, by changing the entry requirements, only around 28,800 weapons and 6 million rounds of ammunition were collected (Knight 2008; Jennings 2008). This totals roughly one gun per four combatants disarmed, but a February 2003 estimate placed the number of weapons in circulation among the various armed forces and rebel groups at three guns per one fighter (Jennings 2007; IRIN 2003). The number of weapons that remain in circulation in Liberia should be alarming to those interested in seeing a lasting peace in the country.

According to Jennings (2008), as part of demobilization ex-combatants were issued an ID card, granted two cash payments of US\$150 each, and provided with access to reintegration programming including formal education, vocational training, public works training, or agricultural training. For those enrolled in reintegration programs, they had all fees paid for up to three years, on top of being granted a monthly living stipend. However, many scholars are critical of the Liberian demobilization process for being counterproductive: too much time, energy, and resources were put into preparing excombatants for jobs that simply didn't exist (Jennings 2008). This results in what Jennings (2007:209) calls a "dangerous disconnect" between disarmament and reintegration in the Liberian DDR process both in terms of capacity-a lack of space in and funding for reintegration programs — and timeliness — with many disarmed combatants unable to access these programs for months, even years.

Furthermore, there is strong evidence that a number of DDR participants were not ex-combatants; they just had access to ammunition (Nichols 2005; Paes 2006). A number 
of noncombatants "cheated" their way into the program by promising certain percentages of cash payments in return for guns or ammunition to hand in (Jennings 2007). As Jennings (2008) explains, many noncombatants she interviewed who had completed the DDR process argued that they suffered too during the war, so why shouldn't they benefit? In Liberia, there was a common feeling that "everybody fought," so assertions that some people were combatants and some were not felt too much like splitting hairs. As long as the combatants received all their benefits, they did not care if their friends and neighbors also benefited from the process. Unfortunately—as scholars like Willibald (2006), Muggah (2007a), and Knight (2008) warned us about in Chapter Two-the cash payment element of the Liberian DDR process created a "market" for ex-combatants. It became profitable to be a combatant; by nature of being a combatant you were rewarded with US\$300 (Jennings 2007). That may not seem like much, but in Liberia at the time of demobilization it was roughly equivalent to a year's salary. By the end of the disarmament and demobilization process in November 2004, many ex-combatants described the DDR program as essentially open-access. One informant explained: "If someone didn't benefit, it's due to their own negligence" (Jennings 2007:212).

Compared to the other DDR programs examined in this Chapter, the female combatants in Liberia seemed to fare well. First, in accordance with UN Security Council Resolution 1325, UNICEF Liberia and other international organizations teamed with the Liberian women's organization calling itself "Women of Liberia Mass Action for Peace," created by feminist social worker Leymah Gbowee, which called for the participation of women representatives at the Accra Peace Conference in Ghana. ${ }^{15}$ Women of Liberia

\footnotetext{
${ }^{15}$ Leymah Gbowee received the Nobel Peace Prize in 2011 for her work with the Liberian women's peace movement.
} 
Mass Action for Peace was so successful in staging nonviolent protests and raising awareness for peace, even hosting frequent sex strikes, that they were able to force a meeting with President Charles Taylor and officially state their terms for peace (Gbowee 2011).

Later, in Ghana, blocking all entrances to the hall where the peace talks were taking place, nearly 200 brave women refused to let a single man leave the negotiation table until a peace deal was signed, denying them water and food. At one point the women even blocked the windows because some of the men were trying to jump from them to get out. It is important to note that it was not some random collection of men inside this room. Representatives from ECOWAS, the UN, and the African Union were present; as was the former head of state of Nigeria, who served as mediator, and the Ghanaian Minster of Foreign Affairs. Most important, representatives from each and every rebel and military group that for two decades had terrorized the people of Liberia were locked inside together. When the security forces came to arrest Gbowee for obstructing justice, she threatened to remove all her clothes in an act of anasyrma, which in many cultures of West Africa is considered a curse. ${ }^{16}$ Any man who witnessed her exposure would be considered dead: no one will cook for him, marry him, or do business with him. It is thought that a young man who sees his own naked mother will become impotent or even die. Refusing to stand down, the women were able to promote the inclusion of gender-specific needs and interests for the formation of the CPA and the resulting DDR process (Gbowee 2011; MacDougall 2011; CNN 2009). In particular,

\footnotetext{
${ }^{16}$ Anasyrma has been a useful tactic for West African women in pushing for socioeconomic change. For example, the women of the Niger Delta used the threat of stripping naked to stop work at oil facilities in protest for the defiling of their communities. Holding the workers hostage for over a week and blocking the production of over half a million barrels of oil for each day, the women took off pieces of clothing to keep the workers in and the police out; see Sealey (2002).
} 
these women fought to have the presence and the rights of the women girls participating in fighting forces to be recognized (UNICEF 2005). ${ }^{17}$

Of the over 100,000 ex-combatants disarmed and demobilized in Liberia, 22,370 were women, 8,523 were boys, and 2,440 were girls (Knight 2008; United Nations 2007). In total, females represented nearly 25 percent of all combatants disarmed and demobilized. For the female ex-combatants who were successfully demobilized, they were provided with medical care, including reproductive health care and HIV education; they also received basic amenities, sexual abuse and trauma counseling, and life skills training. Wherever possible, separate, gender-sensitive facilities were provided (UNICEF 2005). While this is impressive, certainly compared to other DDR programs in Africa, scholars like Specht (2006) and Coulter et al. (2008) argue that possibly as many as 14,000 young female ex-combatants did not formally demobilize. The question is: why?

In their 2004 study, UNIFEM found a number of shortcomings with the DDR program in Liberia as it pertained to female ex-combatants. First, the initial planners of the NCDDRR grossly underestimated the number of females who would require DDR, placing their estimate at a mere 2,000 combatants. The cantonment sites were therefore unprepared to properly accommodate such a large contingency of females. This should have been avoidable since Liberia had the experience of neighboring Sierra Leone's DDR process to use as a guidepost, which proved that a large percentage of women served as active combatants. Second, while the Liberian DDR process was designed to allow for

\footnotetext{
${ }^{17}$ For more information about the women's peace movement in Liberia see the autobiography of Leymah Gbowee, Mighty Be Our Powers: How Sisterhood, Prayer, and Sex Changed a Nation at War (New York: Beast Books, 2011). Also see the acclaimed documentary film Pray the Devil Back to Hell, which documents the women's peace movement.
} 
the processing of dependent female noncombatants along with combatants, no preparations were made to accommodate them (UNIFEM 2004).

Coulter et al. (2008) and Specht (2006) cite other shortcomings to the DDR process in Liberia, which I highlighted in Chapter Two. First, the NCDDRR required the use of lists, made by commanders, of all members within a unit who were to be demobilized. Similar to other DDR processes in Africa, access to DDR in Liberia relied entirely on your name being on a list. If you name is not listed, you cannot receive any of the DDR benefits, including the two cash payments. Female combatants were therefore routinely discriminated against under this system as their names were removed to make room for a commander's friends and family. Second - the same as in Sierra Leone and Burundi-Liberian female combatants were plagued by misinformation. They were routinely tricked out of their weapons by senior, predominately male, commanders (Mazurana 2005; Coulter et al. 2008). For young girls who were "married" to their commanders, it was often the case that their "husbands" forbade them from participating in DDR. If they were not controlled by their "husbands" many young girls and their children were simply abandoned when the fighting ended; these girls often found their way to camps for the internally displaced (Mazurana et al. 2002; UNICEF 1998). Organizations like UNICEF had to work very hard to try to find these girls and help them out of their difficult situations and into rehabilitation and reintegration programs (UNICEF 2005). In a 1998 report, UNICEF provided another insight into why so few girls participated in the DDR process:

In the time leading up to the peace, and immediately following the conflict, females were probably of more use to the faction that the boys, who were no longer fighting. Girls...could still prepare food, clean, fetch water, take care of the younger children, and generally keep 
house...there was little opportunity to reach out to the girls and bring them into the process.

Aside from these reasons, Liberian female ex-combatants also sidestepped the DDR process for reasons iterated in the other case studies: 1) they did not trust the DDR process to actually help them, and 2) they were afraid of repercussions and social stigma if they were identified as ex-combatants (Coulter et al. 2008; UNIFEM 2004). Like their male counterparts, female combatants felt that the international community was making empty promises with the DDR process - jobs, security, peace-it seemed too good to be true. As the process wore on, male and female ex-combatants felt that their lives were no better after demobilization and reintegration. The process was rife with corruption, particularly when transferring cash payments to ex-combatants, and the demobilization and reintegration programming did not provide ex-combatants with enough funds to receive training and still take care of their families. Joseph, an ex-combatant concluded that, if the international community could not provide, it was "better for you to tell the truth" beforehand (Jennings 2007:207).

While the DDR process in Liberia was far from perfect, it represents a shift in the way DDR practitioners should think about and incorporate female combatants into DDR processes. First, did the DDR process in Liberia effectively integrate female combatants? Yes. Compared to the other DDR processes, the Liberia DDR practitioners incorporated female combatants into the initial framework of the DDR process. When they found that few combatants were coming to be disarmed, they expanded the definition so more female combatants without weapons could access the cantonment sites, which led to drastic increases in the number of overall combatants disarmed and demobilized, men and women, boys and girls. Was the DDR process efficient in moving female ex- 
combatants through disarmament and demobilization? Yes, but as I argue above, the process was perhaps too lax in who they let access the sites. Too many noncombatants went through the process, straining the already limited resources of the program and leading to such an overwhelming number of people trying to reintegrate into local communities that there were no jobs and no place for them to go. However, Specht (2006) and Coulter et al. (2008) make it clear that while a significant percentage of female ex-combatants participated in DDR, several thousand more did not. Sociocultural restrictions, conditions within cantonments, corruption, and fear of reprisals kept many from participating who otherwise deserved access to DDR benefits.

Finally, did the DDR process in Liberia exhibit equity in the way it handled male and female combatants? This is a more difficult question to answer clearly. While the DDR process did provide benefits to men and women, and while women could receive specialized treatment in healthcare and counseling, there was not total equality in the process. As I mentioned, a significant number of female ex-combatants were tricked, blocked, and otherwise kept from participating in the process, often at the hands of their own commanders. Perhaps if there was a way to remedy the need for commanding officers to provide combatant lists to cantonment sites, countries like Liberia could sidestep the issue of corruption in the upper and middle ranks of military and militia groups and aim for true gender parity in DDR.

In terms of my initial hypotheses regarding self-reintegration, Liberia is an interesting case. My first hypothesis claims that when governments define female combatants and non-combatants merely as the "dependents" of men it limits their independent agency and forces them to seek reintegration. This is true across the three 
cases examined thus far, but the interesting thing is that the DDR practitioners in Liberia recognized this issue, addressed it in their implementation policy, and corrected it in practice, leading to a huge upswing in the number of women combatants disarmed and demobilized between December 2003 and April 2004. Second, I argue that females without access to guns are blocked from cantonment sites and seek self-reintegration. Again, the DDR practitioners in Liberia initially designed a program that blocked them for this exact reason. However, they adjusted their entrance policy to a mere 150 rounds of ammunition, and suddenly thousands of female ex-combatants could participate. Recognizing the shortcomings in cantonment design in the DDR processes of Sierra Leone and Burundi, Liberia implemented cantonment designs that took into account the special needs of women, segregating them from the male population and providing them with special healthcare, education, and trauma counseling services wherever possible. This could account for why such a large percentage of women chose to participate, supporting my hypothesis that when cantonments cannot supply women ex-combatants with separate facilities, they will chose self-reintegration. Finally, the female excombatants in the Liberian DDR process received access to skills training and education, one of the primary reasons they opted for DDR over self-reintegration in the first place. Unfortunately, the socioeconomic status of post-war Liberia was such that it simply could not support them all with paid employment opportunities, this was true for tens of thousands of Liberian ex-combatant men as well. 


\section{South Sudan: Fight or Flight}

"Given the heightened level of insecurity for women, many were motivated to take up arms...Flight was another recourse open to them."

—-Small Arms Survey (2008)

The conflict in Sudan, now officially divided into the independent countries of Sudan and South Sudan, spans multiple decades. Political power, resource exploitation, ethnic tension, religious intolerance, greed, ignorance — all of these factors played a role in making the Sudan crisis the most violent and costly conflict in terms of loss of human life since the Second World War (Johnson 2003). Between the First Sudanese Civil War (1955-1972) and the Second Sudanese Civil War (1983-2005), well over 2.5 million people died and at least 4 million people were internally and externally displaced. Dissecting this protracted conflict is not easy, so for the sake of brevity I provide only a cursory overview of the events leading up to the signing of the 2005 Sudan Comprehensive Peace Agreement (CPA). ${ }^{18}$

Since the time Sudan was first colonized, the North and South regions were administered as separate entities by Great Britain. This divide made sense. North Sudan is predominately comprised of Arabic-speaking Muslims who identify with North African states like Egypt and Libya. The people of South Sudan are predominately Christian and English-speaking; they identify much more strongly with Sub-Saharan Africa, namely neighbors Kenya, Uganda, and the DRC. However, in 1946 the British government unilaterally decided to unite these two geographically, politically, and socioeconomically disparate regions into one administrative region. Arabic was declared

\footnotetext{
${ }^{18}$ For more information on the history of the conflicts in Sudan see Douglas Johnson's, The Root Causes of Sudan's Civil Wars (The International African Institute, African Issues Series, 2003). Also see Hilde Johnson's Waging Peace in Sudan: The Inside Story of the Negotiations that Ended Africa's Longest Civil War (Sussex: Sussex Academic Press, 2011) and Peter Adwok Nyaba's The Politics of Liberation in South Sudan (Fountain Publishing, 1996).
} 
the official language of North and South Sudan and administrators from the North were given positions of power in the South (Madut-Arop 2006).

In 1953, Great Britain and Egypt agreed to grant independence to the united Sudan, causing increased tension as the South feared being consumed by the more powerful North. To show how little Great Britain understood the power makeup in the region, representatives from South Sudan were not even invited to negotiations during the transitional period. By August 1955, the tension reached a boiling point and North and South Sudan began a violent political conflict, the First Sudanese Civil War, which would last over 16 years and kill half a million people. While most of the fighting took place in South Sudan, over the years the violence spread into the regions of the Nuba Mountains and the Blue Nile (Madut-Arop 2011; Johnson 2003). The violence finally ceased in 1972 with the signing of the Addis Ababa Agreement, which gave religious and cultural autonomy to the South, but this peace was not to last (DeRouen and Heo 2007).

In 1983, after an 11-year ceasefire, then-President Gaafar Nimeiry declared all of Sudan a Muslim state, effectively dissolving the Southern Sudan Autonomous Region. As a result, fighting sparked again, this time between the central Sudanese government and the Sudan People's Liberation Army (SPLA) and its leader, John Garang. The SPLA marketed itself as a movement for all oppressed Sudanese citizens and called for the reinstatement of the Southern Sudan Autonomous Region (Madut-Arop 2006). For twenty years (1983-2003) North and South Sudan fought in a second protracted, bloody civil war. During this conflict at least 2 million Sudanese people died, whether directly from the violence, or indirectly by famine and disease; millions more were displaced 
(Raftopoulos and Alexander 2005). A South Sudanese woman, Nyalok Diu, survived the conflict and shared her story:

We were constantly on the run and had to eat leaves from the trees and lily flowers from the water. We were on the move for many years...I gave birth to my third child in the bush. We had no food. We could not wait for me to recover, the fighting was too close. I gave birth, tied a cloth around me and ran and ran for two, three days (Martin and Pelekemoyo 2012:5).

Peace talks began in earnest between the SPLA and the central Sudan government in 2003 but these negotiations did not pick up speed until 2004. Like in Burundi and Liberia, South Sudanese women were very active in this process, much more active than was reported at the time. Relegated to the margins, women worked tirelessly within grassroots organizations to push their families and communities toward peace. Women actively called for increased female representation in the new South Sudan government, better access to healthcare and education for females, and for the complete separation of South Sudan from North Sudan. According to post-election statistics, at least 52 percent of those who voted for separation were women (Joala and Oder 2012; Yasin 2012). Women are now even speaking out against traditional patrimonial practices including polygamy, bride price, levirate marriages, and early marriages for teen girls. ${ }^{19}$

The Sudan Comprehensive Peace Agreement (CPA), also known as the Naivasha Agreement, was finally signed on January 9, 2005 in Nairobi, Kenya. The CPA provided South Sudan with six years of autonomy before a referendum on independence would be

\footnotetext{
${ }^{19}$ Levirate marriage is a traditional marriage practice whereby the brother of a deceased man in obliged to marry his brother's widow and the widow is obliged to marry the brother. The practice was originally designed to serve as protection for a widow and her children, ensuring that she had a male provider, but the practice is now stigmatized as a form of slavery for women to her husband's family.
} 
put forward. ${ }^{20}$ It also merged portions of the two armies together into one force, the Joint Integrated Units (JIU), and divided oil revenues equally between the government and the SPLA during the period of South Sudan autonomy. Finally, Sharia law was instated in North Sudan while the autonomous government in South Sudan had the option to vote on what elements of Sharia law, if any, would be incorporated through the elected assembly.

DDR was another major element of the peace process that was incorporated into the CPA. It called for the establishing of a National DDR Coordination Council (NDDRCC) run by both a Northern and a Southern Sudan DDR Commission (NSDDRC and SSDDRC, respectively). Each Commission became responsible for designing, implementing, and managing the DDR processes in their respective regions. The "Three Areas" ${ }^{21}$ _South Kordofan and Nuba Mountains, Blue Nile, and Abyei-are jointly run by the two Commissions (Knight 2008). With multiple moving, interconnected pieces, the DDR process was intended to run as quickly and as efficiently as possible. In a radical departure from other DDR programs in Africa, the first two stages were intended to disarm and demobilize combatants in a single day. Each day, those combatants scheduled for DDR were brought to a location 30 kilometers from the cantonment sites where they were disarmed by their own forces then transported to the cantonment for demobilization and discharged as "civilians" by the end of the day (Nichols 2011).

Upon arriving at cantonment sites, ex-combatants receive a reintegration briefing, undergo medical and disability screening, are issued an ID, and are given an assortment

\footnotetext{
${ }^{20}$ Nearly four million South Sudanese citizens voted in the independence referendum from January 9-15, 2011, which passed by an overwhelming 98.83 percent. South Sudan officially declared independence from Sudan on July 9, 2011, making it the newest state in the world since Kosovo declared independence from Serbia in 2008 (Karimi 2011).

${ }^{21}$ These areas are on the border between North and South and Sudan and are hotly contested areas due to the large quantities of oil found there.
} 
of non-food items (NFI), food ration vouchers, and a reinsertion grant of US\$345 for transportation home and initial living expenses. The NFI kits are valued at approximately US\$200 and contain items like a mosquito net, plastic sheeting, and a radio, while the food ration vouchers are enough to feed a family of five for three months. All of the personal information for each ex-combatant is entered into a UN database, called the DREAMS database (Knight 2008; Nichols 2011). As part of the process, Special Needs Groups (SNGs) were particularly targeted for DDR, including the elderly, disabled combatants, women associated with armed forces and groups (WAAFG), and children associated with armed forces and groups (CAAFG). In accordance with the $U N$ Integrated DDR Standards (IDDRS), the WAAFG and CAAFG categories were created to ensure that women and children who played active roles in assisting armed forces and groups, but who were not active combatants, would be included in DDR (Nichols 2011; UN Inter-Agency Working Group on DDR 2006). The estimated caseload for this twopronged DDR process was initially marked by the two sides at over 700,000 combatants, which was flatly rejected by the UN for obvious financial and logistical reasons. After years of negotiation, the consensus figure of 180,000 combatants, 90,000 for each side, was established (Nichols 2011; MYDDRP 2008). ${ }^{22}$

So why did North and South Sudan opt for a DDR process during the 2005 peacemaking process? Nichols (2011) provides a number of reasons. First, as I made clear in Chapter Two, DDR is very much in vogue in the realm of international peacekeeping and peacebuilding; it is seen as a prerequisite for a sustainable peace. Second, DDR is an established method of cantoning and feeding combatants while their

\footnotetext{
${ }^{22}$ The cost of processing the 180,000 combatants through just the first two stages of DDR is estimated to cost US\$135 million; reintegration will cost another US\$430 million (MYDDRP 2008).
} 
transition back into civilian life. Third, DDR can be a very useful way to receive information on the number of combatants and roles of combatants during the violence.

While the Sudan Comprehensive Peace Agreement (CPA) was signed in January 2005, the official National DDR Strategic Plan was not signed until November 2007, and the DDR process was not able to officially launch in North Sudan until February 2009. The South Sudan DDR process did not officially start until August of that year. Since then, progress has been slow, with technical difficulties-including candidate verification and eligibility criteria — and continuing regional security problems stalling the process (Rowe et al. 2009; Muggah 2007b). Furthermore, before Sudan broke apart it was the largest country in Africa. This meant that dozens of cantonment sites would be required, strategically scattered across a vast geographical space. At a number of cantonment sites generators and vehicles broke down. Even if the vehicles worked there was no one to drive them, so there was no way to transport the combatants to and from the sites. Furthermore, unseasonable weather including heavy rains and flooding impacted a number of cantonment sites; this led to an increase in the number of malaria cases. By 2011, less than a quarter of the planned 180,000 ex-combatants were demobilized (Nichols 2011). Estimates place the actual number of combatants from the SPLA who were successfully disarmed and demobilized at around 13 percent (Martin and Pelekemoyo 2012). The UN has attempted to provide support to the disarmament process, but it is run entirely by the Sudan Armed Forces (SAF) in the North and the Sudan People's Liberation Army (SPLA) in the South. The lack of confidence in the DDR process by the SPLA is the main factor behind the lag in South Sudan (Muggah 2007b; Nichols 2011). 
According to Nichols (2011), from the earliest planning stages of the DDR process, the designers knew that many female ex-combatants and WAAFG would be incorporated into the DDR caseload. Estimating the number of female ex-combatants was established using SAF and SPLA payrolls, but estimating the number of WAAFG proved more difficult. As Nichols (2011) explains, the United Nations created the term WAAFG and it is relatively misunderstood by the fighting forces and groups in the Sudan conflict. At no point prior to or during the conflict did fighting forces and groups keep active lists of WAAFG. Furthermore, for those implementing the Northern Sudan DDR program, WAAFG are understood only in the limited capacity of "sex workers" or "sex slaves" so the NSDDRC vehemently denies the existence of WAAFG. Since the NSDDRC denies the existence of WAAFG in Sudan, it was virtually impossible to find any kind of reliable data on DDR that could be incorporated into this study (Jok Madut Jok 1999). Therefore, this case study focuses exclusively on the implementation of female ex-combatants and WAAFG in South Sudan.

Southern Sudanese WAAFG served in the SPLA in a number of vital auxiliary roles. Organized into complex work structures based on age and physical ability, no female was exempt from labor. In the base camps, older women cared for the babies and children born to the WAAFG and those children in the "Red Army" who were forcibly recruited to serve alongside men in battle. Middle-aged women made food and prepared it for transport for the troops; they also gathered food and hunted game with guns. The younger women aged 20-30 years old were responsible for walking to the front with fresh supplies and munitions. Walking for days with heavy loads, sometimes 60 kilometers or 
more, the women would arrive at the front only to turn around and carry out the wounded and injured back to base to be treated (Fitzgerald 2002; Small Arms Survey 2008). Implementing WAAFG has proved to be less of an issue in South Sudan than in the North. As of 2010, the SPLA is required to compile lists of WAAFG, which are then verified through a contracted second party (SSDDRC and UN 2010). For example, according to the SSDRC and the United Nations (2010), at least 1,000 WAAFG were disarmed and demobilized at the cantonment sites at Ed Damazin (South Kordofan) and Julud (Blue Nile). However, DDR practitioners admit that since one of the prime motives of the SPLA in engaging in DDR was to remove salaried soldiers from their payroll, there is less motivation to spend time creating lists of noncombatants, like the WAAFG, who should also be disarmed and demobilized (Nichols 2011).

According to the SAF in North Sudan, there are no children associated with armed forces or groups (CAAFG) in their ranks, so none have been disarmed or demobilized by the joint DDR/UNICEF task force. However, in South Sudan, the SPLA has been more forthcoming with allowing children access to DDR. By 2011 around 3,000 children were demobilized. Nichols (2011) argues that the total number remaining is probably not large, but there are definitely more out there who are not being demobilized or who have opted for self-reintegration. The military activities of girl soldiers in South Sudan are well documented in other conflicts as well. For example, in their 2004 study, McKay and Mazurana note that 72 percent of the Ugandan girls they surveyed reported receiving military training from bases located in South Sudan. Except for those girls who were pregnant or already had small children, all girls were forced through a grueling training regimen. Any child, boy or girl, who dropped from exhaustion during the 
physical training, was left to die in the hot sun. Those who survived were given weapons and forced to fight the South Sudan rebel forces and local civilians (McKay and Mazurana 2004).

For those Sudanese women who participated as active combatants, there are many hurdles blocking easy access to DDR. In a 2008 Issue Brief, the Small Arms Survey examined the success of the DDR process for women combatants and found that it was severely lacking for a number of reasons. First, no one knows exactly how many women participated as active combatants in South Sudan because, in a desperate attempt to downplay women's active participation, the SPLA refused to officially record their involvement, but the numbers range in the thousands (Small Arms Survey 2008). Even the police kept poor records with unconfirmed estimates placing the number of female police officers in South Sudan at approximately 25 percent (Martin and Pelekemoyo 2012). SPLA leader John Garang believed that women should not form a major front-line contingent while the North Sudan's troops were primarily men (Small Arms Survey 2008). This denial has been roundly rebutted by a number of humanitarian agencies and NGOs at work in the region who witnessed females fighting firsthand. Furthermore, Garang forecasted that the conflict would last a long time and women should be held back so as not to sacrifice future generations. Throughout the fighting, women were tasked with "providing children to South Sudan," serving as frontline fighters in what is widely referred to in scholarly works as the "reproductive front" (Hale 1996). Women began having larger families by weaning children earlier and shortening the gaps between pregnancies (McCallum and Okech 2008). As pregnancy rates increased during the height of the conflict, there was virtually no functioning health care system, which 
resulted in one of the highest maternal and infant mortality rates in the world (NSCSE and UNICEF 2004). Through a study conducted by the Global Network of Women Peacebuilders, it is conservatively estimated that the maternal death rate in South Sudan is 2,054 women per 100,000 births (Martin and Pelekemoyo 2012). As Garang admitted:

Decades of underdevelopment and conflict have left South Sudanese women...the poorest of the poor and the most marginalized of the marginalized (Martin and Pelekemoyo 2012).

Faced with crippling insecurity as civilians, many women took up arms as a way to protect themselves and their families. At one point the SPLA had an entire battalion of single women, called the Ketiba Banat or "Girls Cadre", made up of at least 300 volunteers who were trained in neighboring Ethiopia. ${ }^{23}$ Women also served in mixed battalions alongside men, often with their husbands and sons. Within communities they mobilized fighters, smuggling arms between areas, even across enemy lines and national borders (McCallum and Okech 2008; Small Arms Survey 2008). While many women fought, many millions more fled. By 2000, more than 4 million Sudanese people were displaced, primarily women and children, many fleeing into neighboring Kenya, Uganda, and Ethiopia (Small Arms Survey 2008).

Second, although the CPA is over 200 pages long, women are hardly mentioned. In the section devoted to outlining the DDR process, a brief sentence in Annexure I, Part III, Section 24.8 summarizes the gendered element of the process in its entirety:

The DDR programme shall be gender sensitive and shall encourage the participation of the communities and the civil society organizations with the view to strengthening their capacities to play their role in improving and sustaining the social and economic reintegration of former combatants (PAM 2012).

\footnotetext{
${ }^{23}$ This battalion was eventually kept in Ethiopia to perform auxiliary administrative functions for the SPLA throughout the course of the Second Sudanese Civil War (Small Arms Survey 2008).
} 
Within cantonment sites, the DDR Commissions and the United Nations Mission in Sudan (UNMIS) is working to create a gender inclusive environment. In the initial design of the cantonments, female staff members were to be present at all DD locationsincluding security guards, doctors and nurses, speakers, trainers, and HIV/AIDS counsellors. For women combatants and WAAFG who successfully enter cantonment sites, they were supposed to receive gender specific NFI kits that would be more useful to them. Unfortunately, while the DDR Commissions planned the programs with women's best interests in mind, the implementation of these programs is severely lacking. Too few women are qualified to fill the various positions needed at all the cantonment sites including doctors, security, and counsellors (Nichols 2011).

Third, according to the Small Arms Survey (2008), the SPLA's post-conflict reconstruction focus is on neutralizing perceived immediate security threats. Thus, DDR practitioners are pressured by the SPLA to prioritize men over female combatants and WAAFG since men pose the greater security threat. To many SPLA members, WAAFG reintegration is not a security priority, but a "programming nuisance" (Small Arms Survey 2008:4). Many members see the DDR process as a reward system for combatants and veterans, not a means of stabilizing society. Therefore, many are reluctant to see WAAFG benefit from the DDR process when they were not active combatants.

Finally, the issue surrounding sexual violence and cantonments explored in Chapter Two is highly relevant in the case of South Sudan. Rape was used widely across South Sudan as a weapon of war throughout the 22-year conflict. For example, every single interviewee in the Small Arms Survey's (2008) study reported to being raped, knowing a family member who was raped, or knowing someone else who was raped by 
the SAF, SPLA, SSDF, or other rebel groups. The SAF was notorious for entering South Sudanese civilian's homes in the night and raping the females as a form of "punishment" for the SPLA rebellion. Former child soldiers even reported that one of their duties was to collect civilian women for the sole purpose of handing them over to the soldiers for sex (Human Rights Watch 1993; Small Arms Survey 2008). No one was safe-young girls, women carrying babies on their backs, even the elderly were targeted. Pillay (2001) explains that in a number of cases where a young soldier could not penetrate a girl, he would break a bottle and force it into the girl's vagina. Females who suffered this type abuse remained silent and ashamed.

For women in South Sudan, rape and single motherhood carry a serious stigma that keeps many from seeking any form of medical treatment. According to the Small Arms Survey (2008), sexual health service providers struggle to get women to talk about their health problems or to even admit that anything happened to them. If the truth were revealed, these women would lose their "dowry value," making it extremely difficult for them to assimilate back into society and seek husbands. Since the purpose of the South Sudan DDR process was to cycle ex-combatants through in a single day, it is no wonder that most women do not let their guard down and open up to the health screeners about their physical and psychological condition. Furthermore, the majority of WAAFG and female combatants processed through DDR were completely unaware of HIV/AIDS and STI health risks. Properly screening and educating the ex-combatant population on safe sex practices and HIV/AIDS takes time, definitely longer than a single afternoon, time the DDR process as it currently operates does not allow (Small Arms Survey 2008). 
The children of rape victims are just as vulnerable as their mothers. In Sudanese society, women who have children from multiple fathers are highly stigmatized, as are the children. Since the conflict dragged on for so long, families were often separated, leading to uncomfortable reunions when a father long presumed dead returned to find his wife and children living with another man. Under Sudanese law, children from first marriages are often taken away from mothers who have a child with a different man. Often the children are placed with their father's family, which is not always the best or most secure home for them. When a woman's children come from different ethnic groups, the stigmatization can be particularly acute. Often the woman and her children are ostracized by both her home community and the child's father's community.

All of the critiques listed above seem to put the South Sudan DDR process on par with other processes like Burundi and Sierra Leone, which marginalized female combatants. However, since the DDR process is still ongoing, the data is more fluid than in the other cases. This leads me to outline an opposing viewpoint of the DDR process which argues that women have been the primary targets. Scholars like Nichols (2011) and Martin and Pelekemoyo (2012) argue that women, particularly WAAFG, are being targeted by the SPLA for DDR over their male counterparts. For example, according to Martin and Pelekemoyo (2012), of the 13 percent of SPLA forces disarmed and demobilized, the majority of them are female combatants. Fearful of once again witnessing a failed peace between the SPLA and the SAF, the SPLA leadership made the decision to first target the elderly, disabled, and women because "the army had little use for female support during peace time" (Martin and Pelekemoyo 2012:11). Furthermore, countless WAAFG were also cut loose from the organization as a means for the SPLA to 
consolidate and preserve resources. Since WAAFG rely on armed forces or groups for income and social support, in times of peace they become a drain on resources (Nichols 2011). According to various sources, female combatants are expressing anger at being the primary targets for DDR because they are being blocked from receiving equal job opportunities, training, and salaries within military and police forces (Martin and Pelekemoyo 2012).

As the process continues to unfold, we will get a better picture of who was selected for the DDR process and why. Both arguments make sense-men may be targeted because they are seen as more "deserving" of DDR benefits, while women are good targets because it takes the burden off the SPLA for continuing to care for them. Turning to an evaluation of the South Sudan DDR process for female combatants, was the process able to effectively incorporate men and women into the process? No. The unique one-day design of the DDR process should have allowed South Sudan to disarm and demobilize thousands of ex-combatants, but this has not been the case. However, is this the fault of the DDR process, or the hesitant rebel groups who are reluctant to send soldiers for disarmament and demobilization? Nichols (2011) makes it clear that some blame definitely falls on the DDR practitioners for designing poorly organized, understaffed cantonment sites. Early on, everything from lack of doctors to assess the combatants, to faulty generators that could not provide power, to lack of drivers to actually transport combatants to the cantonments to be demobilized plagued the process. These problems have continued across cantonment sites in the North and South.

Next, was the South Sudan DDR process able to efficiently integrate female combatants, did they receive special benefits, training, and healthcare? As I argue above, 
misinformation currently plagues the answer to this question. Some sources argue that women are being purposefully blocked from the process (Small Arms Survey 2008) while others make it clear that women are the primary targets of DDR (Martin and Pelekemoyo 2012; Nichols 2011). However, it should be clear that regardless of the motive, women combatants in South Sudan are being marginalized. If the former is true and women are being sidelined from the DDR process in favor of men, this is an inequitable arrangement; if the latter is true and women are the primary targets of DDR, Martin and Pelekemoyo (2012) and Nichols (2011) have made it clear that they are only being targeted to get them out of the SPLA. Female combatants and WAAFG are being cut loose, which is also a form of marginalization.

While the implementation of DDR in South Sudan for female combatants is not effective, efficient, or equitable, one thing is clear-South Sudan has gone farther than any previous African state examined in this study at integrating non-combatant women into the DDR process through their emphasis on WAAFG. Has this been a perfect process? No. The transition from DDR design to implementation has struggled, but the intent was clear from the beginning that WAAFG are vital members of armed forces and rebel groups and deserve to receive demobilization and reintegration benefits.

Let's turn briefly to an analysis of South Sudan's DDR process in terms of female combatant self-reintegration. First, the stance of North Sudan regarding the military activities of female combatants provides solid proof of the fact that if women are not granted status as combatants, they have no choice but to pursue self-reintegration. North Sudan remains adamant that neither women nor children were active in fighting forces, thus the DDR process had made no allowances for them. South Sudan's emphasis on 
integrating WAAFG has allowed women access to cantonments without a weapon; as a result more women are able to participate. This supports my second hypothesis that if women must present a weapon to be disarmed and demobilized they will seek selfreintegration. However, while DDR practitioners had every intention of providing women with separate facilities, reinsertion packages, skills training, even different doctors, the reality was that there were simply too few women who either already possessed the skills to become staff or who, in the eyes of the DDR practitioners, were simply not trainable. Thus, women entered cantonments and found that their special needs could not be met by the staff on hand. Finally, for those women who felt like they were being jettisoned from the SPLA and forced to accept DDR benefits, they did so knowing that they were being denied further job opportunities in the South Sudan military and police. Some women may be pursuing opportunities outside of DDR in order to continue to make use of their military skills.

The difficulties in providing a succinct analysis of the disarmament and demobilization processes in South Sudan are further complicated by the fact that the new country has remained destabilized by violence since its independence. Everything from cattle rustling to inter-communal rivalries continue to threaten local communities. In an attack in Jonglei in 2012, a 55-year-old woman told Médicines Sans Frontièrs:

On the day of the attack...they set [huts] on fire and threw children in the fire. I collected the children to run away but, because I am old, I cannot run fast and they killed the children...If the children can run, they will shoot them with the gun. It they are small and cannot run, they will kill them with a knife (IRIN 2012).

Jongeli alone recorded at least 302 attacks between January 2011 and September 2012, which resulted in the deaths of over 2,500 people and the displacement of over 200,000 
people (IRIN 2012). As violence has escalated in the various regions of South Sudan, UN officials are calling on the South Sudan government, and particularly the SPLA, to protect women and children. Phumzile Mlambo-Ngcuka, the executive director of UN Women was recently in South Sudan to witness the plight of South Sudanese women and children firsthand. Meeting with a number of displaced women, she reported:

They told me about the lack of food, water and medicine and the lack of safe spaces for them and their children to receive some form of education. They told me about disease and death. And they told me about their yearning for peace in South Sudan (Doki 2014).

Only time will tell what kind of transition South Sudan is able to make, but until continuing violence in the countryside is addressed, the South Sudanese peopleparticularly women — will be no better off than they were during the three decades of conflict that led to South Sudan's independence.

\section{Case Studies in Review}

Before moving on to the final chapter where I address policy recommendations, I want to summarize the findings of my case studies. Each case-Sierra Leone, Burundi, Liberia, and South Sudan — provides a different lens through which to examine the effectiveness, efficiency, and equity of DDR processes for female combatants. For example, Sierra Leone demonstrates the discriminatory effects of a "One Person, One Gun" policy on the disarmament and demobilization of female ex-combatants whereby females who cannot maintain stable access to a weapon are marginalized from the DDR process. The experiences of women in cantonments in Burundi highlight how important it is to offer women a safe and sanitary place to disarm and demobilize. In Liberia, we uncovered the dangers inherent in a DDR program that is too lax and the effect that 
100,000 reintegrating ex-combatants can have on a fragile post-conflict economy and society. Finally, South Sudan showed us how important it is, not only to provide DDR benefits to female combatants, but to WAAFG as well, the undocumented, underappreciated, all-female workforce that makes rebel movements viable.

How do the various DDR programs compare to each other? Table 3 summarizes my findings. Each measurement—effectiveness, efficiency, and equity—is scaled from 0 to 2. A score of zero means that the DDR process failed to incorporate females as it pertains to the given measurement. A score of one is given to a DDR process that had every intention of including female combatants as it pertains to the measurement, but failed to properly implement this gender-inclusive strategy. A score of two is reserved for a gender-inclusive measurement that seems to be fully realized in the DDR process. Each country case study is then given an overall DDR score between 0 and 6 (See Table 3). This score gives us a rough measurement for understanding the overall effectiveness, efficiency, and equity of the first two stages of the DDR process for female excombatants. 
Table 3

Case Study Comparison: Effectiveness, Efficiency, and Equity in Disarmament and Demobilization

\begin{tabular}{|c|c|c|c|c|}
\hline & Sierra Leone & Burundi & Liberia & South Sudan \\
\hline $\begin{array}{l}\text { Effectiveness } \\
\text {-the extent to } \\
\text { which an activity } \\
\text { achieves its } \\
\text { intended } \\
\text { objectives }\end{array}$ & $\begin{array}{l}\text { Score: } 0 \\
\text {-measures were not } \\
\text { put in place to } \\
\text { integrate female } \\
\text { combatants, women } \\
\text { were targeted for } \\
\text { marginalization } \\
\text { through policies } \\
\text { like "One Person, } \\
\text { One Gun"; only } 6.5 \\
\text { percent of } \\
\text { combatants were } \\
\text { female }\end{array}$ & $\begin{array}{l}\text { Score: } 1 \\
\text {-women were not } \\
\text { encouraged to } \\
\text { participate in DDR } \\
\text { so few did, their } \\
\text { role in the design of } \\
\text { the DDR program } \\
\text { was vague; } \\
\text { however } 13 \text { percent } \\
\text { of ex-combatants } \\
\text { disarmed and } \\
\text { demobilized were } \\
\text { women }\end{array}$ & $\begin{array}{l}\text { Score: } 2 \\
\text {-females were } \\
\text { incorporated into } \\
\text { the initial DDR } \\
\text { framework and } \\
\text { steps were taken to } \\
\text { implement this } \\
\text { framework; females } \\
\text { totaled } 25 \text { percent } \\
\text { of all combatants } \\
\text { disarmed and } \\
\text { demobilized }\end{array}$ & $\begin{array}{l}\text { Score: } 0 \\
\text {-in North Sudan no } \\
\text { women entered } \\
\text { DDR, in South } \\
\text { Sudan few female } \\
\text { combatants gained } \\
\text { access, more } \\
\text { WAAFG entered; } \\
\text { no total number of } \\
\text { women in DDR is } \\
\text { known }\end{array}$ \\
\hline $\begin{array}{l}\text { Efficiency } \\
\text {-balance of costs } \\
\text { and benefits }\end{array}$ & $\begin{array}{l}\text { Score: } 0 \\
\text {-women's needs } \\
\text { were not met within } \\
\text { cantonments, many } \\
\text { avoided it citing } \\
\text { security risks; } \\
\text { misinformation } \\
\text { between DDR cites } \\
\text { and rebel groups } \\
\text { disadvantaged } \\
\text { females }\end{array}$ & $\begin{array}{l}\text { Score: } 0 \\
\text {-women's needs } \\
\text { were not met within } \\
\text { cantonments, many } \\
\text { cited security and } \\
\text { health risks; DDR } \\
\text { did not meet their } \\
\text { expectations and } \\
\text { many left before } \\
\text { completing the } \\
\text { process }\end{array}$ & $\begin{array}{l}\text { Score: 1 } \\
\text {-the DDR program } \\
\text { processed several } \\
\text { thousand female } \\
\text { combatants, but } \\
\text { they reintegrated } \\
\text { into a society that } \\
\text { could not support } \\
\text { them; the program } \\
\text { let in too many } \\
\text { noncombatants }\end{array}$ & $\begin{array}{l}\text { Score: } 1 \\
\text {-unlike other states, } \\
\text { South Sudan made } \\
\text { WAAFG a priority, } \\
\text { but the plans put in } \\
\text { place to benefit } \\
\text { women have } \\
\text { struggled, i.e. lack } \\
\text { of female doctors } \\
\text { and special skills } \\
\text { training for women }\end{array}$ \\
\hline $\begin{array}{l}\text { Equity } \\
\text {-basic fairness; } \\
\text { redistributing } \\
\text { benefits to those } \\
\text { in need }\end{array}$ & $\begin{array}{l}\text { Score: } 0 \\
\text {-male combatants } \\
\text { were favored for } \\
\text { DDR over females; } \\
\text { child soldiers fared } \\
\text { better, but girls } \\
\text { were still } \\
\text { marginalized } \\
\end{array}$ & $\begin{array}{l}\text { Score: } 1 \\
\text {-the design of the } \\
\text { peace agreement } \\
\text { encouraged } \\
\text { women's inclusion, } \\
\text { but implementation } \\
\text { was poor }\end{array}$ & $\begin{array}{l}\text { Score: } 1 \\
\text {-the initial design of } \\
\text { the DDR process } \\
\text { included women, } \\
\text { but many were still } \\
\text { blocked by corrupt } \\
\text { military officers }\end{array}$ & $\begin{array}{l}\text { Score: } 0 \\
\text {-whether women } \\
\text { are being blocked } \\
\text { from DDR or } \\
\text { forced into it to } \\
\text { remove them from } \\
\text { the SPLA, they are } \\
\text { being marginalized }\end{array}$ \\
\hline Total Score & $\mathbf{0}$ & 2 & 4 & 1 \\
\hline
\end{tabular}

Based on the summarized information above, it would appear that the most effective disarmament and demobilization process designed to incorporate female combatants occurred in Liberia. The most underperforming DDR process for female ex-combatants was Sierra Leone. However, none of these disarmament and demobilization processes are perfect. As I will explore in the final chapter, each of these case studies teach us something about how DDR practices can be improved to better meet the needs of female ex-combatants in Africa. 


\section{CHAPTER FIVE: POLICY RECOMMENDATIONS}

"While there have been important advances in how DDR programs are designed and implemented, the invisibility and marginalization of women and girls within DDR processes continue."-Mazurana and Cole (2013:194-5)

Each chapter in this thesis serves an important purpose. Chapter One outlined the theoretical problem I am addressing, which is the lack of representative involvement of female combatants in the DDR processes in modern Africa. Where are the female excombatants, and why aren't they participating in DDR? I provide a number of reasons for why females are not participating, including a basic lack of information, forced marginalization, fear of insecurity, and a desire to self-reintegrate. The main point of Chapter One is to explain that, perhaps, the DDR process is not entirely to blame for why women ex-combatants self-reintegrate. Furthermore, there are many reasons why women avoid DDR, even when they know they have access or that they could benefit from participating.

Chapter Two expounds on the Introduction, carefully explicating the DDR process and how female ex-combatants interact with each phase of the process. The point of Chapter Two is to show exactly how and why DDR is failing to incorporate female excombatants. The process - as it currently operates - is broken. The majority of DDR processes begin broken from their inception, or if not broken, grossly underdeveloped. Most initial DDR plans do not incorporate women, thus they are implemented with a 
severe lack of female combatant participation. Furthermore, problems of how to identify female combatants in the wording of peace agreements - are they dependents, combatants, sex slaves, or camp followers - coupled with the issue of corrupt senior officers who downplay the existence of women in fighting forces, results in a low number of females initially recognized as combatants worthy of DDR.

When the problem of how to define female combatants is paired with the problem of how to actually integrate them into disarmament and demobilization processes, you end up with countries like Angola which, despite numerous media reports citing the large number of females actively fighting, only processed 60 females, representing a mere 0.2 percent of the total, through DDR. Or Rwanda, where only 0.06 percent of ex-combatants processed through the DDR program were females (Mazurana and Cole 2013). Worse still are countries like Sudan that are so desperate to say that women did not participate in a three decade long conflict — as soldiers or "camp followers"- that they refuse DDR to all females. By the end of Chapter Two it is clear that, while many female combatants may chose self-reintegration, the DDR process as it currently operates does little to encourage their participation.

Chapter Three is vitally important in this study because it exposes the academy of DDR scholars, analysts, and practitioners as gender-biased and backward-thinking. In the past, too many scholars have allowed their studies to focus only on the experiences of male combatants, or on the vague and unhelpful notion of an ungendered combatant. Furthermore, the majority of case studies focus on the problems faced in reintegrating excombatants into post-conflict societies. This scholarship is definitely needed, but what is also needed is a holistic look at the DDR process that starts from the beginning. That is 
what my research attempts to do. I am filling in the holes left by years of researchers and analysts who have politely ignored the experiences of hundreds of thousands of women and girls across Africa who serve as combatants in modern conflicts. Chapter Four, then, remedies this flaw in the scholarship by providing four in-depth case studies of modern African conflicts that look explicitly at how female ex-combatants are integrated into DDR processes, focusing on the first two steps of the process - disarmament and demobilization. Knowing how females are integrated into the first two stages of the DDR process helps us understand what to expect in terms of how they will eventually reintegrate into civilian society.

Armed with the knowledge of exactly when, where, why, and how DDR is failing female ex-combatants, what policy recommendations should be made to ensure that future DDR programs are better able to achieve gender inclusivity? That is what this final chapter will address. I will focus on four main recommendations that echo my original hypotheses regarding why female ex-combatants choose to self-reintegrate. These recommendations are loosely labeled: 1) combatant status, 2) better cantonment access, 3) increased cantonment security, and 4) equal opportunities.

\section{Combatant Status}

My first hypothesis regarding female combatants in the DDR process argues that, as long as they are labeled as the "dependents" of men-women have been officially labeled as sex slaves, bush wives, and camp followers in various African conflicts- their independent agency as active combatants is denied. When women are not recognized as combatants, they are routinely blocked from participating in DDR processes, as well as 
from all the benefits and assistance that these processes afford. Other feminist scholars like Mazurana and Cole (2013) support my analysis. In "Women, Girls, and

Disarmament, Demobilization, and Reintegration (DDR)" they write:

The invisibility of women and girls in formal DDR programs is often due to a narrow definition and understanding of what makes a person a "combatant" in fighting forces or groups (Mazurana and Cole 2013:202).

This is exactly what happened to the female combatants in the DDR programs in Sierra Leone and Burundi. For example, the Arusha Peace and Reconciliation Agreement in Burundi states that the "special needs" of women soldiers are to be addressed, but no details are provided on what is a woman soldier. Who qualifies as a woman soldier and who doesn't? What are the "special needs" women soldiers have that will be addressed? The Agreement is unclear on all these points (Alusala 2005).

In order to ensure that female combatants are recognized as parties eligible for DDR, governments and DDR practitioners must be clear about what it means to be a "combatant" and who qualifies for combatant status. This means determining what actions constitute those of a combatant and what actions are performed by "camp followers." This distinction must be made in the initial peace agreements that outline how the DDR processes are to proceed. The vague language used in the peace agreements of Sierra Leone and Burundi does not ensure that female ex-combatants are properly represented in DDR programs. Until the rights of female combatants, rather privileged or unprivileged, are secured in the initial framing of peace agreements, they will continue to fall through the cracks. The DDR process in South Sudan is taking a significant step in this direction by delineating the status of women involved with armed forces and groups as either combatants or WAAFG (Small Arms Survey 2008; Nichols 2011). Obviously, 
women's identities within armed forces and groups are often intersectional, at the same time they are both a victim and a perpetrator, combatant and servant. However, the "either or" distinction used in South Sudan is one way of moving African DDR processes toward achieving enhanced gender sensitivity in program design and implementation, ultimately recognizing and admitting that women do serve in active combatant and vital auxiliary martial roles.

\section{Better Cantonment Access}

Clearly establishing the status of female combatants in the body of peace agreements will not ensure that they are granted access to cantonment sites. Therefore, more must be done in terms of how the disarmament and demobilization processes are implemented to guarantee that those female combatants who are eligible and who wish to participate in DDR are able to gain access. My second hypothesis argues that various DDR access policies like “One Person, One Gun” in Sierra Leone, and similarly strict rules that require combatants to present an AK-47, like in Liberia, restrict access to cantonments for female combatants (Mazurana and Cole 2013). Research clearly shows that while females actively serve as combatants, many do not maintain access to an AK47, or indeed any weapon (Koyama 2009; Kingma 1997; Farr et al. 2009b; Mackenzie 2009). When they fail to present a weapon at cantonment sites their status as a combatant is delegitimized and many are forced to seek self-reintegration.

These strict access policies not only hurt female combatants; they marginalize scores of men and boys who also serve in armed forces and groups in auxiliary roles. The Liberian DDR process made it clear that when DDR access rules are relaxed, many more 
male and female ex-combatants become eager to participate in disarmament and demobilization (Jennings 2008, 2008; Knight 2008). However, when Liberia adjusted its cantonment access policy from presenting an AK-47 to presenting 150 rounds of ammunition, the number of combatants seeking disarmament and demobilization went from barely a trickle to a flood. The cantonment site outside Monrovia was overwhelmed by the number of combatants eager to disarm and demobilize, including a significant number of noncombatants who "cheated" their way in (Jennings 2007, 2008). The cantonment access policy in Liberia should serve as both a model and a cautionary tale for DDR scholars and analysts. Ideally, future DDR designers and practitioners can learn from the Liberian DDR experience to craft cantonment access policies that are equitable to both male and female combatants, yet are not so lax that anyone who shows up with a handful of ammunition can receive DDR benefits. Ultimately, DDR practitioners must keep in mind that just because someone does not have access to a weapon, does not mean they are not a combatant.

\section{Increased Cantonment Security}

Assuming DDR practitioners learn their lesson and craft cantonment access policies that allow for a gender-representative ${ }^{24}$ intake of male and female combatants, how do they ensure that female combatants complete the DDR process? My third hypothesis makes the claim that until cantonments can be designed in such a way to present females with a safe environment to disarm and demobilize, they will continue to

\footnotetext{
${ }^{24}$ I use "gender-representative" instead of "gender-balanced" or "gender-equal" to imply that DDR programs should be representative of the estimated gender makeup of the various armed forces and groups. In the case of countries like Sierra Leone, there was roughly a 70-30 split between males and females, while in countries like Eritrea and the DRC the proper representation in DDR was closer to 80-20 for males and females. True gender parity would be inaccurate and unattainable.
} 
self-reintegrate. The research supports this conclusion. The most frequently cited problem by female ex-combatants with cantonment across the four case studies is insecurity (Mackenzie 2009; McKay and Mazurana 2004; Denov 2009; UNICEF 2005; Coulter et al. 2008). Female ex-combatants feel insecure physically in the sense that living conditions within cantonments are often very poor, lacking sufficient food, water, sanitation, and shelter (Mazurana 2004). Furthermore, the threat of sexual harassment and violence looms heavy in the hearts of those eager to escape those who for years perpetrated violence against them. If women know they will be locked inside a cantonment with the same soldiers who abused them, they feel forced to self-reintegrate for their own safety. In Burundi, the majority of female ex-combatants surveyed by UNICEF (2005) explained that if cantonments were segregated by sex they would have participated.

To ensure the proper safety of male and female combatants during the disarmament and demobilization phases of DDR, cantonment sites must be designed to protect the combatants from further violence and insecurity. The best solution would be to design separate cantonment facilities for women and men. This policy of gender segregation was intended for the DDR processes in Burundi, Liberia, and South Sudan, but many cantonments failed to properly implement the plans, often due to a lack of females able to be trained to perform the various cantonment staff functions (Nichols 2011; Mazurana 2004). Many of the staffing and operational problems can be addressed in the initial planning stages of the DDR process. For example, the DDR planners in Liberia completely underestimated the number of female combatants that would seek disarmament and demobilization (UNIFEM 2004). Had these planners used the 
experiences in Sierra Leone as an example, it would have been clear from the beginning just how many female ex-combatants would potentially seek out cantonment sites.

As disarmament and demobilization get underway, cantonment sites for females could benefit from the experiences and skills of the ex-combatants themselves to fill potential staffing voids. As Mazurana and Cole (2013) argue, many female combatants spend years in armed forces and groups honing transferable skills in scare-resource management, mediation and conflict resolution, decision-making, medicine and first aid, team building, weapons handling, risk assessment, and grassroots mobilization. DDR organizers could draw on the skills of these women to assist other female combatants by helping them turn over weapons, complete demobilization paperwork, and seek medical assistance. As a female ex-combatant from Sierra Leone argues, "Girls...should be involved in developing programs because they know where their interests lie" (Denov 2009:27).

Increased security within cantonments is one way to ensure more women participate, but this will not encourage all women to disarm and demobilize through official DDR processes. The research makes it very clear that females self-reintegrate for a number of reasons including fear of undergoing medical treatment and fear of being harassed and abused (McKay 2004; Mazurana and Cole 2013). Furthermore, females are much more likely than males to want to immediately break all ties with armed forces and groups (Humphreys and Weinstein 2007). Many are under intense pressure to convert back into the gendered status quo and assume their "proper" place within their family and community structure (McKay 2004; McKay and Mazurana 2004; Mazurana and Cole 
2013; Mazurana 2004 and 2005). In the case studies we saw this happen in Sierra Leone, Burundi, and Liberia.

This brings us to a very important question: is cantonment the right method of demobilization for female combatants? Clearly, until the problems with how cantonments are organized and operated can be addressed, female ex-combatants will continue to be wary of the process and will slip into the margins of the system. Some countries are already attempting to address female combatants' need to self-reintegrate. In Ethiopia, women combatants reported to their home communities for ex-combatant registration instead of cantonment sites (Knight and Özerdem 2004). Creative thinking like this will go a long way in ensuring that female combatants receive the best treatment possible while completing DDR.

\section{Equal Opportunities}

My final policy recommendation involves ensuring that female combatants receive equal access to all DDR benefits, including health screenings, skills training, job placement, and reinsertion packages. In Chapter Three, my final hypothesis argued that if women perceive that they are receiving unequal treatment their sense of marginalization increases and they will seek self-reintegration. All the research supports this hypothesis. In each case study I provide proof of female ex-combatants who felt marginalized from the DDR process and who did not receive equal skills training, education, and job opportunities compared to their male counterparts, particularly in terms of being competitive for new roles in government militaries and police forces (McKay and Mazurana 2004; Nichols 2011; Jennings 2007, 2008). In African countries like Sierra 
Leone, Burundi, and Liberia, female combatants who participated in the DDR process felt that the process was not actually helping ex-combatants - male or female - to reintegrate (Mackenzie 2009; Mazurana 2004; Jennings 2007). In Chapter Four I shared the words of a female ex-combatant in Burundi who argued: "The progress of the DDR process is doubtful, it is not moving forward as expected...As time goes by, women and girls are feeling they have been abandoned" (Mazurana 2004:63).

Ensuring equal opportunities for male and female combatants begins with education. De Watteville (2002) argues that women are often much less aware of their rights then are men. DDR practitioners should therefore begin by providing information to female combatants about what benefits they are eligible to receive, where to obtain them, what their rights are (i.e. right to possess land, right to vote, right to a divorce), and how to make sure those rights are respected (De Watteville 2002). In Liberia and Burundi, during the respective peace processes, women's organizations worked tirelessly to promote civic education and women's rights (UNICEF 2005; World Bank 2013). For example, Burundian women knew they could not count on the DDR process to provide education and training to ex-combatants, so a number of women's organizations were developed to fill this void. Various Burundian women's organizations have crafted their own demobilization and reintegration programs for female combatants that focus on promoting women's legal rights, teaching marketable skills, and providing psychological support and counseling (World Bank 2013). These organizations host fundraisers for items like food, blankets, and clothing that are given to female ex-combatants and their families. 
Furthermore, since the end of the conflict, Burundian women have worked to rebuild a number of schools and homes and have built centers designed specifically to aid those combatants and WAAFG who were subjected to trauma and sexual violence (Kadende-Kaiser 2012; World Bank 2013). This type of community engagement should encourage DDR practitioners and let them know that they are not alone. By sharing knowledge and skills across grassroots nongovernmental organizations like those in Burundi, DDR processes for female combatants will be able to better specialize to meet the specific needs of women and girls. The more opportunities female combatants have to see how their skills can be put to use in civilian society, they more likely they are to make a more positive transition out of their military roles.

\section{Conclusion}

With the passing of UN Security Council Resolution 1325 in October 2000, the international community of states received a call to action: make the world a safer, more equitable place for women and girls (Cohn et al. 2004; DeLargey 2013). The research presented in this thesis makes it clear that the majority of African states are failing to hear this call and properly adjust their DDR practices to be more inclusive for female excombatants. However, there is hope for the peacemaking and peacebuilding processes in Africa. As states suffering from violent political conflicts work to mainstream a gendered perspective into peacekeeping and peacebuilding operations, creating a more genderconscious DDR framework will provide female combatants and WAAFG with a safe space in which to pursue a transition into civilian life. The four policy recommendations outlined in this chapter are all feasible options for how African DDR processes can better 
incorporate female ex-combatants. Indeed, many of these recommendations are already in place, in part or in whole, in various countries. As governments and DDR practitioners develop their skills and become better able to fully implement gender inclusive DDR policies, we will hopefully see a shift in how many female combatants seek out disarmament and demobilization through official DDR programs. This, in turn, will increase the number of women who successful reintegrate back into civilian society.

The benefits of creating gender inclusive DDR processes in Africa are numerous. First, from a national security perspective, the more females governments are able to persuade to participate in official DDR programs, the more information they can glean about the size and scope of rebel organizations and the roles of female combatants within them (Knight and Ozerdem 2004; Berdal 1996; Colleta et al. 1996). Second, the demobilization phase of the process provides health practitioners with the opportunity to assess various health risks within the country including HIV/AIDS and STIs, as well as a population from which to gather data for other figures like infant and maternal mortality rates (Berdal 1996; Colleta et al. 1996; De Watteville 2002). For countries like Sudan, Mozambique, and Burundi that were plagued by overlapping civil wars and periods of violence for decades, demobilization may be the first time health practitioners have access to large populations of women and their children to assess threats to health and human security.

Third, DDR processes that incorporate WAAFG into eligibility parameters will be able to assist the thousands of females in Africa who are forcibly recruited to join rebel organizations, serving for years as domestic workers and sex slaves. Gender segregated cantonment sites will separate them from their captors and provide them with the 
healthcare and psychological counseling they need to begin to rebuild their lives (Turshen 2001; Mazurana 2013; Sommers 1997; Coulter et al. 2008; Nordstrom 1998; Mazurana et al. 2002). Finally, female combatants who are granted full access to all DDR benefits and programs will be given the opportunity to redirect the course of their postwar lives. Rather than return to their prewar positions as housewives and mothers, through DDR female ex-combatants would have the chance to learn how to best use their skills and experiences to help rebuild the postwar economy (Mazurana and Cole 2013; World Bank 2013).

Ultimately, female combatants need to know that they are useful and needed, that their years of suffering were not endured in vain, and that there is a place for them in a new political and social order where peace and equality are promoted and protected as universal human rights for both men and women. In the words of Leymah Gbowee, the leader of the women's peace movement in Liberia: "You can tell people of the need to struggle, but when the powerless start to see that they really can make a difference, nothing can quench the fire" (Gbowee 2011). Empowering female ex-combatants to take an active role in their own disarmament and demobilization is a proactive way to ensure that they are given the tools to improve, not only their lives, but the lives of their children, families, and communities.

Looking to the future for this research project, a number of important questions remain. First, returning to the closing of Chapter One, is the use of female combatants and noncombatants in violent conflicts a uniquely African phenomenon? How many women are actively engaged in the fighting in the ongoing conflicts of Syria, Colombia, or Yemen? Without knowing the rate at which females are actively involved as 
combatants in other world conflicts, we cannot know how generalizable my policy recommendations are to conflicts outside Africa. Second, now that I have painted a clear picture of the various paths females take through the disarmament and demobilization stages - complete with all its road blocks and potholes—-how can we better understand the ways in which females approach reintegration? I avoided any real discussion of reintegration in this piece for the simple fact that so many scholars already focus on it in their research. However, now that we have learned so much about the first two stages, it is necessary to bring reintegration back in and examine the DDR process holistically.

Eventually, I would like to take the field of DDR research even further, going beyond the classic foci of viewing DDR processes from the perspective of combatants and look instead through the eyes of civilians. How do civilians see the DDR process, what do they think about the reintegration of tens of thousands of ex-combatants into their communities? This is a very unique and vitally important perspective that, like the perspective of female combatants, is not traditionally considered in DDR research. Therefore, in a future project I would like to reanalyze one or all of the African DDR case studies evaluated here from the civilian perspective; this would require extensive fieldwork that was not possible in this project. The fact that there are "stones left unturned" in the field of DDR research should not be seen as a negative, rather, it means that there is still much more we as scholars can do to make sense of the process and improve it for the future generations of male and female ex-combatants who will need help transitioning back into peaceful, productive, civilian lives. 


\section{REFERENCES}

Abdullah, Ibrahim

(2004) Between Democracy and Terror: The Sierra Leone Civil War (Dakar: Council for the Development of Social Science Research in Africa).

Adibe, Clement

(1995) Managing Arms in Peace Processes: Somalia. Disarmament and Conflict Resolution Project (Geneva: UN Institute for Disarmament Research).

Advocates for Human Rights, The

(2009) "A House with Two Rooms: Final Report of the Liberia Truth and Reconciliation Commission Diaspora Project”. June 19: pp. 245.

AFELL (Association of Female Lawyers of Liberia)

(1998) "Hundreds of Victims Silently Grieving" in Turshen and Twagiramariya (eds.) What Women Do in Wartime: Gender and Conflict in Africa (London: Zed Books), pp. 129-137.

Alden, Christopher

(2002) "Making Old Soldiers Fade Away: Lessons from the Reintegration of Demobilized Soldiers in Mozambique" in Security Dialogue 33(3), pp. 341-356.

Anderlini, Sanam and Dyan Mazurana

(2004) "Boys and Girls Who Also Carries Guns: Forgotten in the Peace" in International Herald Tribune, op-ed, 12 March 2004.

Annan, Jeannie, Moriah Brier, and Filder Aryemo

(2009) 'From 'Rebel' to 'Returnee: The Reintegration of Young Soldiers in Northern Uganda" in Journal of Adolescent Research 24(6), pp. 639-667.

Annan, Jeannie, Christopher Blattman, Dyan Mazurana, and Khristopher Carlson (2011) "Civil War, Reintegration, and Gender in Northern Uganda" in Journal of Conflict Resolution 55(6), pp. 877-908.

Antonio de Abreu, Alcinda

(1998) "Mozambican Women Experiencing Violence" in Meredeth Turshen and Clotilde Twangiramariya (eds.) What Women do in Wartime (London: Zed Books), pp. 73-84.

Babiker, Mohammed Hassan and Alpaslan Özerdem

(2003) "A Future Disarmament, Demobilization, and Reintegration Process in Sudan: Lessons Learned from Ethiopia, Mozambique, and Uganda" in Conflict, Security, and Development 3(2), pp. 211-232.

Barron, Michelle 
(1996) When the Soldiers Come Home: A Gender Analysis of the Reintegration of Demobilized Soldiers-Mozambique 1994-96 (School of Development Studies of East Anglia: United Kingdom).

Barth, Elise

(2002) Peace as Disappointment: The Reintegration of Female Soldiers in Postconflict Societies: A Comparative Study from Africa (Oslo: Peace Research Institute).

Bell, Edward and Charlotte Watson

(2006) DDR: Supporting Security and Development: The EU's Added Value (London: International Alert).

Berdal, Mats

(1996) Disarmament and Demobilization after Civil Wars. Adelphi Paper 303.

(Oxford: Oxford University Press).

Bernales Ballesteros, E.

(1994) "Report on the Question of the Use of Mercenaries as a Means of Violation Human Rights and Impeding the Exercise of the Right of Peoples to Self-Determination" submitted by the Special Rapporteur of the Commission on Human Rights. Document A/49/362 (New York City: United Nations).

Blattman, Christopher and Jeannie Annan

(2010) "The Consequences of Child Soldiering" in Review of Economics and Statistics 92(4), pp. 882-898.

Bolton, Catherine

(2012) I Did It to Save My Life: Love and Survival in Sierra Leone (Berkeley: University of California Press).

Bonnerjea, Lucy

(1994) "Disasters, Family Tracing, and Children's Rights: Some Questions about the Best Interests of Separated Children" in Disasters 18:3 (Oxford: United Kingdom).

Bowen, Michael

(1973) Passing By: The United States and Genocide in Burundi, 1972 (Carnegie Endowment for International Peace).

Burman, M.E. and Susan McKay

(2007) "Marginalization of Girl Mothers during Reintegration from Armed Groups in Sierra Leone" in International Nursing Review 54; pp. 316-323.

Burnet, Jennie

(2012) "Situating Sexual Violence in Rwanda (1990-2001): Sexual Agency, Sexual Consent, and the Political Economy of War" in African Studies Review 55(2); pp. 97-118.

Card, Cynthia

(1996) "Rape as a Weapon of War" in Hypatia 11(4), pp; 5-18.

Carlson, Khristopher and Dyan Mazurana

(2008) Forced Marriage with the Lord's Resistance Army, Uganda (Medford, MA: Feinstein International Center, Tufts University).

Carpenter, Charli

(2006) Innocent Women and Children: Gender Norms and the Protection of 
Carter, April

Civilians (Aldershot: Ashgate).

(1998) "Should Women be Soldiers of Pacifists?" in Lorentzen and Turpin (eds.) The Women and War Reader (New York: New York University Press), pp. 33-41.

$\mathrm{CNN}$

(2009) “African Women Look within for Change", CNN, 31 October 2009, http://edition.cnn.com/2009/WORLD/africa/10/30/africa.women/, accessed 22 February 2014.

Coalition to End the Use of Child Soldiers

(2000) Americas Report. http://www.childsoldiers.org/americas.

(2001) Child Soldiers Global Report (London: Author).

Cockburn, Cynthia

(2001) "The Gendered Dynamics of Armed Conflict and Political Violence" in Moser, Caroline et. al. (eds.) Victims, Perpetrators, or Actors: Gender, Armed Conflict, and Political Violence (London: Zed Books), pp. 13-29.

Cohen, Dara Kay

(2013) "Female Combatants and the Perpetuation of Violence Wartime Rape in the Sierra Leone Civil War" in World Politics 65(3), pp. 383-415.

Cohn, Carol, Helen Kinsella, and Sheri Gibbings

(2010) "Women, Peace and Security Resolution 1325" in International Feminist Journal of Politics 6(1), pp. 130-140.

Colletta, Nat, Markus Kostner, and Ingo Weidehofer

(1996) The Transition from War to Peace in Sub-Saharan Africa (Washington DC: World Bank).

Collier, Paul

(1994) "Demobilization and Insecurity: A Study in the Economics of the Transition from War to Peace" in Journal of International Development 6(3); pp. 343-351.

Corbin, Joanne

(2008) "Returning Home: Resettlement of Formerly Abducted Children in Northern Uganda" in Disasters 32(2), pp. 316-335.

Correia, Maria

(2009) "Disarm, Demobilize, and Reintegrate: Transforming Combatants into Citizens to Consolidate Peace" in Development Outreach 11(2); pp. 16.

Coulter, Chris

(2008) "Female Fighters in the Sierra Leone" in Feminist Review 88(1); pp. 5473.

(2009) Bush Wives and Girl Soldiers: Women's Lives through War and Peace in Sierra Leone (Ithaca: Cornell University Press).

Coulter, Chris, Mariam Persson and Mats Utas

(2008) "Young Female Fighters in African Wars: Conflict and its Consequences" in Nordiska Afrikainstitutet Policy Dialogue 3 (Uppsala: The Nordic African Institute).

Crelinsten, Ronald

(1995) "In Their Own Words: The World of the Torturer" in Crelinsten and 
Daly, Mary

Schmid (eds.) The Politics of Pain: Torturers and their Masters (Oxford: Westview Press).

(1984) Pure Lust: Elemental Feminist Philosophy (London: The Women's Press).

De Alwis, Malathi, Julie Mertus, and Tazreena Sajjad

(2013) "Women and Peace Processes" in Carol Cohn (ed.) Women and Wars (Cambridge: Polity Press), pp. 169-193.

DeLargy, Pamela

(2013) "Sexual Violence and Women's Health in War" in Carol Cohn (ed.)

Women and Wars (Cambridge: Polity Press), pp. 54-79.

Douglas, Sarah and Felicity Hill

(2004) Getting it Right, Doing it Right: Gender and Disarmament, Demobilization and Reintegration (United Nations Development Fund for Women).

Denov, Myriam

(2006) "Wartime Sexual Violence: Assessing a Human Security Response to War-Affected Girls in Sierra Leone" in Security Dialogue 37(3); pp. 319342.

(2009) Girls in Fighting Forces: Moving Beyond Victimhood. A Summary of the Research Finding on Girls and Armed Conflict from the CIDA's Child Protection Research Fund.

Denov, Myriam and Richard Maclure

(2005) Child Soldiers in Sierra Leone: Experiences, Implications, and Strategies for Community Reintegration. Report for the Canadian International Development Agency.

(2009) "Girls and Small Arms in Sierra Leone:" Victimization, Participation, and Resistance" in Farr et al. (eds.) Sexed Pistols: The Gendered Impacts of Small Arms and Light Weapons (New York City: United Nations University Press), pp. 51-80.

Derluyn, Ilse, Eric Broekaert, Gilberte Schuyten, and Els De Temmerman

(2004) "Post-traumatic Stress in Former Ugandan Child Soldiers" in The Lancet 363(9412); pp. 861-863.

DeRouen, Karl and Uk Heo

(2007) Civil Wars of the World: Major Conflicts Since World War II (ABCCLIO).

Desai, Meghnad

(2003) "Lords Hansard" in Speech in the House of Lords, referenced by Willibald "Does Money Work? Cash Transfers to Ex-combatants in Disarmament, Demobilization and Reintegration Processes" in Disasters 30(3): 2006, pp. 316-339.

De Waal, Alex

(2013) "Playing the Genocide Card" in The New York Times.

http://www.nytimes.com/2013/12/19/opinion/playing-the-genocidecard.html?hpw\&rref=opinion\&_r=1\&. (Accessed 3 January 2014).

De Watteville, Nathalie

(2002) Addressing Gender Issues in Demobilization and Reintegration Programs 
Doki, Charlton

(Africa Region Working Paper Series 33: World Bank).

(2014) "Women Bear Brunt of South Sudan Conflict, UN Official Says" in Voice of America, 19 February 2014, http://www.voanews.com/content/southsudan-un-women-rape-unrest-violence/1855125.html, accessed $11 \mathrm{March}$ 2014.

Dzinesa, Gwinyayi

(2007) "Postconflict Disarmament, Demobilization, and Reintegration of Former Combatants in Southern Africa" in International Studies Perspectives 8(1), pp. 73-89.

Edmonds, Martin, Greg Mills, and Terence McNamee

(2009) "Disarmament, Demobilization, and Reintegration and Local Ownership in the Great Lakes: The Experience of Rwanda, Burundi, and the Democratic Republic of the Congo" in African Security 2(1), pp. 29-58.

El Jack, Amani

(2003) Gender and Armed Conflict, Overview Report BRIDGE, Institute of Development Studies, University of Sussex.

Enloe, Cynthia

(1993) The Morning After: Sexual Politics at the End of the Cold War (Berkeley: University of California Press).

(2000a) Maneuvers: The International Politics of Militarizing Women's Lives (Berkeley: University of California Press).

(2000b) Bananas, Beaches, and Bases: Making Feminist Sense of International Politics (Berkeley: University of California Press).

Faltas, Sami

(2001) "In Search of a 'Best Practice' of Micro-Disarmament" in Faltas et al. (eds.) Managing the Remnants of War: Micro-Disarmament as an Element of Peace-Building (Baden-Baden: Nomos Verlagsgesellschaft); pp. 211230.

Farr, Vanessa

(2002) Gendering Demilitarization as a Peacebuilding Tool (Bonn: Bonn International Center for Conversion).

Farr, Vanessa, Henri Myrttinen, and Albrecht Schnabel

(2009a) Sexed Pistols: The Gendered Impacts of Small Arms and Light Weapons (New York City: United Nations University Press).

(2009b) "Sexing the Pistol: The Gendered Impacts of Prolific Small Arms" in Farr et al. (eds.) Sexed Pistols: The Gendered Impacts of Small Arms and Light Weapons (New York City: United Nations University Press), pp. 317.

Fitzgerald, Mary Anne

(2002) Throwing the Stick Forward: The Impact of War of Southern Sudanese Women (Nairobi: UNIFEM/UNICEF).

Frey, Waldemar and Henri Boshoff

(2005) "Burundi's DDR and the Consolidation of the Peace" in African Security Review 14(4); pp. 43-46.

Friedman-Rudovsky, Jean 
(2013) "The Women who Bear the Scars of Sierra Leone's Civil War" in The Telegraph. 16 November 2013.

http://www.telegraph.co.uk/news/worldnews/africaandindianocean/sierral eone/10450619/The-women-who-bear-the-scars-of-Sierra-Leones-civil-

Gamba, Virginia war.html. Accessed 17 January 2014.

(1999) Small Arms in Southern Africa: Reflections on the Extent of the Problem and its Management Potential. ISS Monograph 42. (Pretoria: ISS).

Gberie, Lansana

(2005) A Dirty War in West Africa: The RUF and the Destruction of Sierra Leone (Indiana University Press).

Gbowee, Leymah

(2011) Mighty Be Our Powers: How Sisterhood, Prayer, and Sex Changed a Nation at War (New York: Beast Books).

Geddes, Barbara

(1990) "How the Cases You Choose Affect the Answers You Get: Selection Bias in Comparative Politics" in Political Analysis 2: pp. 131-152.

Giddens, Anthony

(1999) "Political Theory and the Problem of Violence" in The Politics of Human Rights, pp. 246-248.

Gilligan, Michael, Eric Mvukiyehe and Cyrus Samii

(2013) "Reintegrating Rebels into Civilian Life: Quasi-Experimental Evidence from Burundi" in Journal of Conflict Resolution 57(4), pp. 598-626.

Glasius, Marlies

(2008) "We Ourselves, We are part of the Functioning: The ICC, Victims, and Civil Society in the Central African Republic" in African Affairs 108(430), pp. 49-67.

Gleichmann, C., Michael Odenwald, Kees Steenken, Adrian Wilkinson

(2004) Disarmament, Demobilization, and Reintegration: A Practical Field and

Classroom Guide. Eschborn, Deutsche Gesellschaft für Technische

Zusammenarbeit (GTZ, Germany), Swedish National Defense College,

Pearson Peacekeeping Centre (Canada) and Forscarets skoesenter

(Norway).

Goldblatt, Beth and Shelia Meintjes

(1998) "South African Women Demand Truth" in Turshen and Twagiramariya et. al. (eds.) What Women do it Wartime: Gender and Conflict in Africa (Zed Books: London), pp. 27-61.

Goose, Stephen and Frank Smyth

(1994) "Arming Genocide in Rwanda" in Foreign Affairs 73(5); pp. 86-96.

The Guardian

(2003) "Liberian Rebels Declare Ceasefire" in The Guardian, 29 July 2003, http://www.theguardian.com/world/2003/jul/29/westafrica?INTCMP=ILC NETTXT3487, accessed 22 February 2014.

Hale, Sondra

(1996) Gender and Politics in Sudan: Islamism, Socialism, and the State (Boulder: Westview Press). 
Hanlon, Joseph

(2004) "Is it Possible to just Give Money to the Poor" in Development and Change 35(2), pp. 375-383.

Harris, B.L.

(1995) "Rape and the Liberian Conflict" unpublished manuscript.

Harsch, Ernest

(2005) "Women: Africa's Ignored Combatants" in Africa Renewal, (New York: United Nations University Press), pp. 17.

Harvey, Paul

(2005) "Cash and Vouchers in Emergencies" HPG Discussion Paper. February. Overseas Development Institute, London.

http://www.odi.org.uk/sites/odi.org.uk/files/odi-assets/publicationsopinion-files/432.pdf. Accessed 12 December 2013.

Hirsch, John

(2001) Sierra Leone: Diamonds and the Struggle for Democracy (Boulder: Lynne Rienner Publishers).

Hobson, Matt

(2005) Forgotten Causalities of War: Girls in Armed Conflict (London: Save the Children).

Högbladh, Stina

(2011) "Peace Agreements 1975-2011 - Updating the UCDP Peace Agreement Dataset" in Pettersson Therése and Lotta Themnér (eds.) State in Armed Conflict 2011 (Uppsala University: Department of Peace and Conflict Research Report 99).

Human Rights Watch

(1993) Civilian Devastation: Abuses by All Parties to the War in Southern Sudan (London: Human Rights Watch).

Humphreys, Macartan and Jeremy Weinstein

(2007) "Demobilization and Reintegration" in Journal of Conflict Resolution 51(4), pp. 531-567.

Ibanez, Ana Cristina

(2001) "El Salvador: War and Untold Stories-Women Guerrillas" in Moser, Caroline et. al. (eds.) Victims, Perpetrators, or Actors: Gender, Armed Conflict, and Political Violence (London: Zed Books), pp. 117-130.

IRIN (Integrated Regional Information Network)

(2003) "Warring Factions Walk Out of Disarmament Talks," 27 November 2003, http://www.irinnews.org/report/47460/liberia-warring-factions-walk-outof-disarmament-talks, accessed 21 February 2014.

(2010) "Burundi: Female Ex-Combatants Picking up the Pieces," 5 February 2010, http://www.irinnews.org/report/88006/burundi-female-excombatants-picking-up-the-pieces. Accessed 21 February 2014.

(2012) "South Sudan: Women and Children Bear Brunt of Jonglei Violence," 5 December 2012, http://www.irinnews.org/report/96972/south-sudanwomen-and-children-bear-brunt-of-jonglei-violence, accessed 11 March 2014.

Isima, Jeffrey 
(2004) "Cash Payments in Disarmament, Demobilization, and Reintegration Programs in Africa" in Journal of Security Sector Management 2(3); pp. $1-10$.

ISIS (Women's International Cross-Cultural Exchange)

(1998) Documenting Women's Experiences in Armed Conflict Situations in Uganda 1980-1986, Luwero District: A Research Report (Kampala, Uganda: Author).

Jacobson, Ruth

(2005) "Gender, War, and Peace in Mozambique and Angola: Advances and Absences" in Dyan Mazurana et. al. (eds.) Gender, Conflict, and Peacekeeping (Oxford: Rowman and Littlefield); pp. 134-149.

Jaye, Thomas

(2003) "Liberia: An Analysis of Post-Taylor Politics" in Review of African Political Economy 30(98).

Jennings, Kathleen

(2007) "The Struggle to Satisfy: DDR through the Eyes of Ex-combatants in Liberia" in International Peacekeeping 14(2), pp. 204-218.

(2008) "Unclear Ends, Unclear Means: Reintegration in Postwar Societies-The Case of Liberia" in Global Governance 14, pp. 327-345.

Joala, Refiloe and Sandra Oder

(2012) "Independence Not Providing Dividends for Women in South Sudan" in All Africa, 26 July 2012, http://allafrica.com/stories/201207260762.html, accessed 11 March 2014.

Johnson, Douglas

(2003) The Root Causes of Sudan's Civil Wars (The International African Institute: African Issues Series).

Johnson, Hilde

(2011) Waging Peace in Sudan: The Inside Story of the Negotiation that Ended Africa's Longest Civil War (Sussex: Sussex Academic Press).

Johnson, James Buttolph and H.T. Reynolds (2012) Political Science Research Methods (Los Angeles: CQ Press).

Johnson, Kristin, Jennifer Scott, Bigy Rughita, Michael Kisielewski, Janan Asher, Ricardo Ong, and Lynn Lawry

(2010) "Association of Sexual Violence and Human Rights Violations with Physical and Mental Health in Territories of the Eastern Democratic Republic of the Congo" in Journal of the American Medical Association 304(5); pp. 553-562.

Jok Madut Jok

(1999) "Militarization and Gender Violence in South Sudan" in Journal of Asian and African Studies 34(4); pp. 427-442.

Kadende-Kaiser, Rose

(2012) "Frontline Peacebuilding: Women's Reconstruction Initiatives in Burundi" in Schnabel and Tabyshalieva (eds.) Defying Victimhood: Women and Post-Conflict Peacebuilding (New York: United Nations University Press), pp. 118-142.

Karimi, Faith 
(2011) "Complete Preliminary Results Show 99\% Vote to Split Southern Sudan" in CNN World, 30 January 2011, http://www.cnn.com/2011/WORLD/africa/01/22/sudan.referendum.results /index.html?_s=PM:WORLD, accessed 26 February 2014.

Keen, David

(2005) Conflict and Collusion in Sierra Leone (Oxford: James Currey).

King, Gary, Robert Keohane, and Sidney Verba

(1994) Designing Social Inquiry: Scientific Inference in Qualitative Research

(Princeton: Princeton University Press).

Kingma, Kees

(1997) "Demobilization of Combatants after Civil Wars in Africa and their Reintegration into Civilian Life" in Policy Studies 30(3), pp. 151-165.

Kinzelbach, Katrin and Zeinab Mohamed Hassan

(2009) "Poems Against Bullets? The Role of Somali Women in Social Gun Control" in Farr et al. (eds.) Sexed Pistols: The Gendered Impacts of Small Arms and Light Weapons (New York City: United Nations University Press), pp. 356-389.

Klingebiel, S., I. Gärke, C. Kreidler, S. Lobner, and H. Schütte

(1995) "Promoting the Reintegration of Former Female and Male Combatants in Eritrea" (Berlin: German Development Institute).

Knight, Mark and Alpaslan Özerdem

(2004) "Guns, Camps and Cash: Disarmament, Demobilization, and Reinsertion of Former Combatants in Transitions from War to Peace" in Journal of Peace Research 41(4), pp. 499-516.

Knight, W. Andy

(2008) "Disarmament, Demobilization, and Reintegration and Post-Conflict

Peacebuilding in Africa: An Overview" in African Security 1(1), pp. 2452.

Koyama, Shukuko

(2009) "Just a Matter of Practicality: Mapping the Role of Women in Weapons for Development Projects in Albania, Cambodia, and Mali" in Farr et al. (eds.) Sexed Pistols: The Gendered Impacts of Small Arms and Light Weapons (New York City: United Nations University Press), pp. 329-355.

Krishnan, Sonny Inbaraj

(2011) "The Transition of Teenage Girls and Young Women from Ex-Combatants to Civilian Life: A Case Study in Sri Lanka" in Intervention 9(2): pp. 137144.

Krog, Antjie

(2001) "Locked into Loss and Silence: Testimonies of Gender and Violence at the South Africa Truth Commission" in Moser, Caroline et. al. (eds.) Victims, Perpetrators, or Actors: Gender, Armed Conflict, and Political Violence

Last, David (London: Zed Books), pp. 203-216.

(1999) "The Human Security Problem - Disarmament, Demobilization and Reintegration" in A Source Book on the State of the Art in Post-Conflict Rehabilitation, unpublished report prepared by PRDU for Regional Socio- 
Lemarchand, René

Economic Development Program for Southern Lebanon (York: PRDU, University of York).

(1974) Selective Genocide in Burundi (Report-Minority Rights Group; no. 20).

(1996) Burundi: Ethnic Conflict and Genocide (New York: Woodrow Wilson Center and Cambridge University Press).

(2009) The Dynamics of Violence in Central Africa (Philadelphia: University of Pennsylvania Press).

Liberia National Police

(2006) Annual Crime Report and Statistics for 2005 (Monrovia, Liberia: Liberia National Police).

Lindsey, Charlotte

(2000) "Women and War" in International Review of the Red Cross 839; pp. 561579.

Longman, Timothy

(1998) Proxy Targets: Civilians in the War in Burundi (Human Rights Watch).

Lorentzen, Lois Ann and Jennifer Turpin

(1998) The Women and War Reader (New York: New York University Press).

Lundin, Irae Baptista, M. Chachiua, A. Gaspar, H. Guebuza, and G. Mbilana

(2000) "Reducing Costs through an 'Expensive Exercise': The Impact of

Demobilization in Mozambique" in Kingma, Kees (ed.) Demobilization in

Sub-Saharan Africa. The Development and the Security Impacts

(Houndmills: Macmillan Press).

MacDougall, Claire

(2011) "Liberian Women Pray as the Nation Heads to the Polls" in The Christian Science Monitor, 6 October 2011, http://www.csmonitor.com/World/Africa/2011/1006/Liberian-womenpray-as-the-nation-heads-to-the-polls, accessed 21 February 2014.

Mackenzie, Megan

(2009) "Securitization and Desecuritization: Female Soldiers and the Reconstruction of Women in Post-conflict Sierra Leone" in Security Studies 18, pp. 241-261.

Madut-Arop, Arop

(2006) Sudan's Painful Road to Peace: A Full Story of the Founding and Development of SPLM/SPLA (BookSurge Publishing).

Martin, Rita and J.N. Pelekemoyo

(2012) The Republic of South Sudan a Women Count, Security Council

Resolution 1325: Civil Society Monitoring Report (Global Network of Women Peacebuilders).

Mason, Christine

(2005) "Women, Violence, and Nonviolent Resistance in East Timor" in Journal of Peace Research 42(6): pp. 737-749.

Mazurana, Dyan

(2004) Women in Armed Opposition Groups Speak on War, Protection, and 
Obligations under International Humanitarian and Human Rights Law

(Geneva: Geneva Call and the Program for the Study of International Organizations).

(2005a) Women in Armed Opposition Groups in Africa and the Promotion of International Humanitarian Law and Human Rights. Report of a workshop organized in Addis Ababa by Geneva Call and the Program for the Study of International Organizations, Nuvember 23-26, University of Geneva.

(2005b) "Gender and the Causes and Consequences of Armed Conflict" in Mazurana et al. (eds.) Gender, Conflict, and Peacekeeping (Oxford: Rowman and Littlefield Publishers), pp. 29-42.

(2013) "Women, Girls, and Non-State Armed Opposition Groups" in Carol Cohn (ed.) Women and Wars (Cambridge: Polity Press), pp. 146-168.

Mazurana, Dyan and Khristopher Carlson

(2004) From Combat to Community: Women and Girls of Sierra Leone (Hunt Alternatives Fund).

Mazurana, Dyan and Linda Eckerbom Cole

(2013) "Women, Girls, and Disarmament, Demobilization, and Reintegration (DDR)" in Carol Cohn (ed.) Women and Wars (Cambridge: Polity Press), pp. 194-214.

Mazurana, Dyan, Susan McKay, Khristopher Carlson, and Janel Kasper

(2002) "Girls in Fighting Forces and Groups: Their Recruitment, Participation, Demobilization, and Reintegration" in Peace and Conflict: Journal of Peace Psychology 8(2); pp. 97-123.

Mazurana, Dyan, Angela Raven-Roberts, and Jane Parpart

(2005) Gender, Conflict, and Peacekeeping (Oxford: Rowman and Littlefield Publishers).

McCallum, Judith and Alfred Okech

(2008) "Small Arms and Light Weapons Control and Community Security in Southern Sudan: The Links between Gender Identity and Disarmament" in Regional Security, Gender Identity, and CPA Implementation in Sudan (Ontario: Pandora Press); pp. 35-58.

McConnan, Isobel and Sarah Uppard

(2001) Children, Not Soldiers (London: Save the Children).

McKay, Susan

(1998) "The Psychology of Societal Reconstruction and Peace: A Gendered Perspective" in L.A. Lorentzen and Jennifer Turpin (eds.) The Women and War Reader (New York: New York University Press), pp. 348-362.

(2004) "Reconstructing Fragile Lives: Girls' Social Reintegration in Northern Uganda and Sierra Leone" in Gender and Development 12(3), pp. 19-30.

McKay, Susan and Dyan Mazurana

(2004) Where are the Girls? Girls in Fighting Forces in Northern Uganda, Sierra Leone, and Mozambique: Their Lives During and After War (Montreal:

Rights and

Democracy).

McKay, Susan, Malia Robinson, Maria Gosalves, and Miranda Worthen 
(2006) "Girls Formerly Associated with Fighting Forces and their Children: Returned and Neglected" in Washington R, Coalition to Stop the Use of Child Soldiers. Available at http://child-soliders.org/psycho-social/english, pp. 1-14.

McMullin, Jaremey

(2004) "Reintegration of Combatants: Were the Right Lessons Learned in Mozambique?” in International Peacekeeping 11(4); pp. 625-643.

MDRP (Multi-country Demobilization and Reintegration Program)

(2007) MDRP Quarterly Progress Report, April-June 2007 (Washington D.C.: MDRP Secretariat).

Mehreteab, Amanuel

(2007) Assistance to War Wounded Combatants and Individuals Associated with Fighting Forces in Disarmament, Demobilization, and Reintegration Programs (Centre for Humanitarian Dialogue: Cornell University).

Moser, Caroline

(2001) "The Gendered Continuum of Violence and Conflict: An Operational Framework" in Moser, Caroline et. al. (eds.) Victims, Perpetrators, or Actors: Gender, Armed Conflict, and Political Violence (London: Zed Books), pp. 30-52.

Moser, Caroline and Fiona Clark

(2001) "Introduction" in Moser et al. (eds.) Victims, Perpetrators, or Actors:

Gender, Armed Conflict, and Political Violence (London: Zed Books), pp. 3-12.

Mpoumou, Doris

(2004) 'Women's Participation in Peace Negotiations: Discourse in the Democratic Republic of the Congo' in Julie Ballington (ed.) The Implementation of Quotas: African Experiences (Stockholm: International Institute for Democracy and Electoral Assistance) pp. 120-123.

Muggah, Robert

(2004) "The Anatomy of Disarmament, Demobilization, and Reintegration in the Republic of Congo" in Conflict, Security, and Development 4(1), pp. 2137.

(2007a) "No Magic Bullet: A Critical Perspective on Disarmament, Demobilization, and Reintegration (DDR) and Weapons Reduction in Post-conflict Contexts" in The Roundtable: The Commonwealth Journal of International Affairs 94(379), pp. 239-252.

(2007b) "Great Expectations: (Dis)integrated DDR in Sudan and Haiti" in Humanitarian Exchange 37, pp. 25-28.

Mwakikagile, Godfrey

(2012) Burundi: The Hutu and the Tutsi: Cauldron of Conflict and Quest for Dynamic Compromise (New Africa Press).

MYDDRP (Multi-Year Disarmament, Demobilization, and Reintegration Programme) (2008) "Multi-Year Disarmament, Demobilization, and Reintegration Project" unpublished document (Khartoum: GoS, UNDP, UNMIS, and UNICEF).

National Council for DDR Co-ordination (NCDDRC)

(2002) Reintegration of Ex-Combatants: Transition from War to Peace- 
Management of a Complex DDR Process, volume 1 (Freetown, Sierra Leone: National Council for DDR Co-ordination, May 2002).

Nichols, Ryan

(2005) "Disarming Liberia: Progress and Pitfalls" in Nicholas Florquin and Eric Berman (eds.) Armed and Aimless: Armed Groups, Guns and Human Security in the ECOWAS Region (Geneva: Small Arms Survey); pp. 108143.

(2011) DDR in Sudan: Too Little, Too Late? (Switzerland: Small Arms Survey). Nordstrom, Carolyn

(1998) "Girls Behind the (Front) Lines" in L.A. Lorentzen and Jennifer Turpin (eds.) The Women and War Reader (New York: New York University Press), pp. 80-89.

NSCSE (New Sudan Centre for Statistics and Evaluation) and UNICEF (UN Children's Fund)

(2004) Towards a Baseline: Best Estimates of Social Indicators for Southern Sudan. NSCSE Series Paper No. 1 (New York: NSCSE/UNICEF).

Nyaba, Peter Adwok

(1996) The Politics of Liberation in South Sudan (Fountain Publishing).

Olonisakin, Funmi

(1995) "Liberia" in Bennett et al. (eds.) Arms to Fight - Arms to Protect: Women Speak about Conflict (London: Panos).

Onyango, Grace, Angelina Atyam, Christopher Arwai, and Gladys Jane Acan

(2005) "Girl Mothers of Northern Uganda" in Conference on Girl Mothers in Fighting Forces and their Post-War Reintegration in Southern and Western Africa. Bellagio, Italy.

Paes, Wolf-Christian

(2006) "The Challenges of Disarmament, Demobilization, and Reintegration in Liberia" in International Peacekeeping 12(2), pp. 253-261.

Peace Accords Matrix (PAM)

(2012) Peace Accords Matrix. https://peaceaccords.nd.edu/. Kroc Institute for International Peace Studies, University of Notre Dame (accessed 18 October 2013).

Peppiatt, David, John Mitchell, and Penny Holzmann

(2001) Cash Transfers in Emergencies: Evaluating Benefits and Assessing Risks. Humanitarian Practice Network Paper. 35. June. http://www.odihpn.org/documents/networkpaper035.pdf. Accessed 17 December 2013.

Peteet, Julie

(1997) "Icons and Militants: Mothering in the Danger Zone" in Signs 23(1)

Peters, Krijn

(University of Chicago Press), pp. 103-129.

(2007) "Reintegration Support for Young Ex-combatants: A Right or a

Privilege?" in International Migration 45(5), pp. 35-59.

Peters, Krijn and Paul Richards

(1998) "Why We Fight: Voices of Youth Combatants in Sierra Leone" in Africa: Journal of the International African Institute 68(2), pp. 183-210. 
Physicians for Human Rights

(2000) Preliminary Findings and Recommendations on the Health Consequences of Human Rights Violations during the Civil War. Unpublished Report.

Pillay, Anu

(2001) "Violence Against Women in the Aftermath" in Meintjes et al. (eds.) The Aftermath: Women in Post-Conflict Transformation (London: Zed Books), pp. 35-45.

Popovic, Nicola, Minna Lyytikainen, and Corey Barr

(2010) Planning for Action on Women and Peace and Security: National-Level Implementation of Resolution 1325 (United Nations Press).

Porto, João and Imogen Parsons

(2003) "Sustaining the Peace in Angola: An Overview of Current Demobilization, Disarmament and Reintegration", Article 27 (Bonn: Bonn International Center for Conversion).

(2011) Sustaining the Peace in Angola: An Overview of Current Demobilization, Disarmament, and Reintegration (Institute for Security Studies).

Pouligny, Beatrice

(2004) The Politics and Anti-Politics of Contemporary Disarmament, Demobilization, and Reintegration Programs (Paris: CERI/SGDN).

Powell, Ivor and Bianca Capazorio

(2012) "UN Slams SA's 'Private Army" in IOL News. http://www.iol.co.za/news/south-africa/gauteng/un-slams-sa-s-privatearmy-1.1373943\#.UFNFz8jdGnQ. Accessed 14 February 2014.

Puechguirbal, Nadine

(2003) "Women and War in the Democratic Republic of the Congo" in Signs 28(4), pp. 1271-1281.

Pugel, James

(2009) "Measuring Reintegration in Liberia: Assessing the Gap between Outputs and Outcomes" in Robert Muggah (ed.) Security and Post-Conflict Reconstruction: Dealing with Fighters in the Aftermath of War (New York: Routledge), pp. 70-102.

Raftopoulos, Brian and Karin Alexander

(2005) Peace in the Balance: The Crisis in Sudan (Institute for Justice and Reconciliation).

Rasheed, Ahmed and Ross Colvin

(2007) "Iraqi Police Selling Weapons on Black Market" in Reuters. 5 February 2007.

Raven-Roberts, Angela

(2005) "Gender Mainstreaming in United Nations Peacekeeping Operations: Talking the Talk, Tripping over the Walk" in Mazurana et al. (eds.) Gender, Conflict, and Peacekeeping (Oxford: Rowman and Littlefield Publishers), pp. 43-64.

Rehn, Elisabeth and Ellen Sirleaf

(2002) Women, War and Peace: The Independent Experts; Assessment of Armed Conflict on Women and Women's Role in Peacebuilding (New York: United Nations Development Fund for Women). 
Report of the Secretary-General

(2000) The Role of United Nations Peacekeeping in Disarmament, Demobilization, and Reintegration. S/2000/101 (New York: United Nations Security Council).

Riley, Stephen and Max Sesay

(1996) "Liberia: After Abuja" in Review of African Political Economy 23(69); pp. 429-437.

Ruwanpura, Kanchana and Jane Humphries

(2004) "Mundane Heroines: Conflict, Ethnicity, Gender, and Female Hardships in Eastern Sri Lanka" in Feminist Economics 10(2); pp. 173-205.

Sabatier, Paul

(2007) Theories of the Policy Process (Westview Press).

Salamon, Lester and Odus Elliott

(2002) The Tools of Government: A Guide to the New Governance (Oxford: Oxford University Press).

Schnabel, Albrecht and Anara Tabyshalieva

(2012) Defying Victimhood: Women and Post-Conflict Peacebuilding (United Nations University Press).

Schroeder, Emily

(2005) "A Window of Opportunity in the Democratic Republic of the Congo: Incorporating a Gender Perspective in the Disarmament, Demobilization, and Reintegration Process" in Peace, Conflict and Development. Access the PDF at http://www.bradford.ac.uk/ssis/peace-conflict-anddevelopment/issue-5/AWindowofOpportunity.pdf. (Accessed 19 October 2013).

Sealey, Geraldine

(2002) "Naked Ploy is Latest Threat in Oil Wars" in Common Dreams, 31 July 2002, http://www.commondreams.org/headlines02/0731-08.htm, accessed 22 February 2014.

Sesay, Max

(1996) "Politics and Society in Post-War Liberia" in The Journal of Modern African Studies 34(3); pp. 395-420.

Shepherd, Laura

(2008) "Power and Authority in the Production of United Nations Security Council Resolution 1325" in International Studies Quarterly 52(2), pp. $383-404$.

Shikola, Teckla

(1998) "We Left Our Shoes Behind" in M. Turshen and C. Twagiramariya et. al. (eds.) What Women do it Wartime: Gender and Conflict in Africa (Zed Books: London), pp. 138-149.

Sideris, Tina

(2003) "War, Gender, and Culture: Mozambican Women Refugees" in Social Science \& Medicine 56(40), pp. 713-724.

Sjoberg, Laura

(2010) "Women and Political Violence: Female Combatants in Etho-National Conflicts" in International Feminist Journal of Politics 12(2), pp. 285- 
287.

Skinner, E. Benjamin

(2008) A Crime So Monstrous: Face-to-Face with Modern-Day Slavery (New York: Free Press).

Smet, Stijn

(2009) "A Window of Opportunity: Improving Gender Relations in Post-conflict Societies: The Sierra Leonean Experience" in Journal of Gender Studies 18(2), pp. 147-163.

Smith, Kevin and Christopher Larimer

(2013) The Public Policy Theory Primer (Westview Press).

Smith, Steven

(1999) "Burundi: At the Brink of Humanitarian Tragedy" in Refugees International. http://reliefweb.int/node/54120. Accessed 19 February 2014.

Sommers, Marc

(1997) The Children's War: Towards Peace in Sierra Leone. A Field Report Assessing the Protection and Assistance Needs of Sierra Leonean Children and Adolescents.

Spear, Joanna

(2006) "From Political Economies of War to Political Economies of Peace: The Contribution of DDR after Wars of Predation" in Contemporary Security Policy 27(1); pp. 168-189.

Specht, Irma

(2006) Red Shoes: Experiences of Girl Combatants in Liberia (Geneva

Switzerland: International Labour Office).

SSDDRC and the UN

(2010) "DDR Join Standard Operating Procedure-SOP 103: WAAF Identification and Verification in South Sudan" unpublished document (Juba: South Sudan).

Stavrou, Vivi

(2004) Breaking the Silence: Girls Abducted During Armed Conflicts in Angola.

Report for the Canadian International Development Agency.

Stavrou, Stavros, Robert Stewart, and Amanda Stavrou

(2000) "The Reintegration of Child Soldiers and Abductees: A Case Study of

Palaro ad Pabbo, Gulu District, Northern Uganda" in Selected

Proceedings from the International Conference on War-Affected Children (New York: Joint Publication of Department of Foreign Affairs and International Trade, Ottawa, and United Nations Children's Fund).

Swiss, Shana

(1991) "Liberia: Women and Children Gravely Mistreated" Physicians for Human Rights, May, Boston, mimeo.

(1992) “Liberia: Anguish in a Divided Land" Physicians for Human Rights, May, Boston, mimeo.

Swiss, Shana, Peggy Jennings, Gladys Aryee, Grace Brown, Ruth Jappah-Saumaki, Mary Kamara, Rosana Schaack, and Rojatu Turay-Kanneh

(1996) "Violence against Women During the Liberian Civil Conflict" in Journal 
Szesnat, Felicity

of the American Medical Association 279(8); pp. 625-629.

(2009) "Small Arms and Rape as a System of War: A Case Study of the

Democratic Republic of the Congo" in Farr et al. (eds.) Sexed Pistols: The

Gendered Impacts of Small Arms and Light Weapons (New York City:

Tanner, Fred United Nations University Press), pp. 81-106.

(1996) "Consensual Versus Coercive Disarmament" in Managing Arms in Peace Processes: The Issues. (Geneva: United Nations Institute for Disarmament Studies), pp. 169-204.

Thompson, Carol

(1999) "Beyond Civil Society: Child Soldiers as Citizens in Mozambique" in Review of African Political Economy 26(80)' pp. 191-206.

Totten, Samuel, William Parsons, and Israel Charny

(2004) Century of Genocide: Critical Essays and Eyewitness Accounts (Routledge).

Tryggestad, Torunn

(2009) "Trick of Treat? The UN and Implementation of Security Council Resolution 1325 on Women, Peace, and Security" in Global Governance: A Review of Multilateralism and International Organizations 15(4), pp. 539-557.

Turshen, Meredeth

(1998) "Women's War Stories" in M. Turshen and C. Twagiramariya et. al. (eds.) What Women do it Wartime: Gender and Conflict in Africa (Zed Books: London), pp. 1-26.

(2001) "The Political Economy of Rape: An Analysis of Systematic Rape and Sexual Abuse of Women during Armed Conflict in Africa" in Moser, Caroline et. al. (eds.) Victims, Perpetrators, or Actors: Gender, Armed Conflict, and Political Violence (London: Zed Books), pp. 55-68.

Turshen, Meredeth and Clotilde Twangiramariya

(1998) What Women do in Wartime: Gender and Conflict in Africa (London: Zed Books).

Twagiramariya, Clotilde and Meredeth Turshen

(1998) "'Favours' to Give and 'Consenting' Victims: The Sexual Politics of Survival in Rwanda" in M. Turshen and C. Twagiramariya et. al. (eds.) What Women do it Wartime: Gender and Conflict in Africa (Zed Books: London), pp. 101-117.

UNICEF (United Nations Children's Fund)

(1998) The Disarmament, Demobilization, and Reintegration of Child Soldiers in Liberia 1994-1997: The Process and Lessons Learned (New York: Author).

(2005) "The Impact of Conflict on Woemn and Girls in West and Central Africa and the UNICEF Response" UNICEF, February 2005, accessed at http://www.unicef.org/publications/files/Impact_final.pdf. Accessed 14 February 2014.

UN Inter-Agency Working Group on DDR 
(2006) Integrated Disarmament, Demobilization, and Reintegration Standards (IDDRS) (New York and Geneva: United Nations).

United Nations

(2001) United Nations High Commissioner for Human Rights, Report on the Human Rights Situation in Sierra Leone. A/56/281, United Nations, New York, 9 August 2001.

(2005) "Disarmament, Demobilization, Reintegration (DDR), and Stability in Africa." United Nations Office of the Special on Africa and the Government of the Republic of Sierra Leone. http://www.un.org/africa/osaa/reports/DDR\%20Sierra\%20Leone\%20Marc h\%202006.pdf Accessed 18 February 2014.

(2006) Integrated Disarmament, Demobilization and Reintegration Standards. United Nations. http://pksoi.army.mil/doctrine_concepts/documents/ UN\%20Guidelines/IDDRS.pdf. Accessed 18 December 2013.

(2007) "Country Programme: Liberia" in United Nations Disarmament, Demobilization ,and Reintegration Resource Centre, http://www.unddr.org, accessed 21 February 2014.

(2008) "Operational Guide to the IDDRS". Accessed 08 January 2014.

United Nations Department of Peacekeeping Operations (UNDPKO)

(1999) Disarmament, Demobilization, and Reintegration of Ex-Combatants in a Peacekeeping Environment: Principles and Guidelines (New York: United Nations).

United Nations Disarmament, Demobilization, and Reintegration (UNDDR)

(2006) 'Integrated Disarmament, Demobilization, and Reintegration Standards: Glossary: Terms and Definitions'. New York: United Nations Disarmament, Demobilization, and Reintegration. www.unddr.org/iddrs/01/download/IDDRS_120.pdf (accessed 27 September 2013).

United Nations Security Council (UNSC) (2000) "Resolution 1325" United Nations Security Council.

(2006) "International Commission of Inquiry for Burundi: Final Report." United Nations Security Council. S/1996/682 Part I:1:2. http://www.usip.org/sites/default/files/file/resources/collections/commissi ons/Burundi-Report.pdf. Accessed 18 February 2014.

Uvin, Peter

(2007) Ex-Combatants in Burundi: Why They Joined, Why They Left, How They Fared (Washington DC: Multi-country Demobilization and Reintegration Program/Work Bank).

Veale, Angela

(2003) "From Child Soldier to Ex-Fighter: Female Fighters, Demobilization and Reintegration in Ethiopia" in ISS Monograph Series 85. (Pretoria: Institute for Security Studies).

Verhay, Beth

(2001) "Child Soldiers: Preventing, Demobilizing and Reintegration" in Africa Region Working Paper Series 23 (World Bank).

(2004) Reaching the Girls: Study on Girls Associated with Armed Forces and 
Groups in the Democratic Republic of the Congo. Save the Children UK and the NGO Group: CARE, IFESH, and IRC, London.

Verwimp, Philip

(2006) "Machetes and Firearms: The Organization of Massacres in Rwanda" in Journal of Peace Research 43(5); pp. 5-22.

Waters, Esther and Geneva Call

(2008) "No Standing, Few Prospects: How Peace is Failing South Sudanese Female Combatants and WAAFG" in Sudan Issue Brief: Human Security

Willet, Susan Baseline Assessment 13; pp. 1-8.

(2010) "Introduction: Security Council Resolution 1325: Assessing the Impact on Women, Peace and Security" in International Peacekeeping 17(2), pp. 142-158.

Williamson, John

(2006) "The Disarmament, Demobilization, and Reintegration of Child Soldiers: Social and Psychological Transformation in Sierra Leone" in Intervention

\section{Willibald, Sigrid} 4(3), pp. 185-205.

(2006) "Does Money Work? Cash Transfers to Ex-combatants in Disarmament, Demobilization and Reintegration Processes" in Disasters 30(3), pp. 316339.

Women's Commission for Refugee Women and Children

(2001) Against All Odds: Surviving the War on Adolescents (New York:

Women's Commission.

(2002) Precious Resources: Adolescents in the Reconstruction of Sierra Leone (New York: Women's Commission).

World Bank

(2002) "Sierra Leone: Disarmament, Demobilization, and Reintegration (DDR)" in Findings Infobriefs 81 (African Region, October 2002).

(2013) "Female Ex-Combatants find Livelihoods and Acceptance in Burundi" in World Bank. 19 September 2013.

http://www.youtube.com/watch?v=QPYpJMuqQFA. Accessed 18

December 2013.

Yasin, Sara

(2011) "How Will Women Fare in the World's Newest Country?" in Ms.Magazine: Blog, 10 July 2011, http://msmagazine.com/blog/2011/07/10/how-will-women-fare-in-the-

Yeung, Christina worlds-newest-country/, accessed 11 March 2014.

(2009) "Missing Men, Lost Boys, and Widowed Women: Gender Perspective on Small-Arms Proliferation and Disarmament in Karakoja, Uganda) in Farr et al. (eds.) Sexed Pistols: The Gendered Impacts of Small Arms and Light Weapons (New York City: United Nations University Press), pp. 390-418. 


\title{
CURRICULUM VITAE
}

\author{
EMILY K. MAIDEN \\ 606 Merwin Avenue Louisville, KY 40217 \\ (859) $816-1100$ \\ emilyrath01@yahoo.com
}

\section{EDUCATION}

- Ph.D. Political Science and Peace Studies, University of Notre Dame (expected 2019)

- M.A. Political Science, University of Louisville (2014)

- B.A. Political Science, summa cum laude, minor in Asian Studies, University of Louisville (2011)

- B.A. Philosophy, University of Louisville (2011)

- Diploma in Asian Studies, Kansai Gaidai University, Osaka, Japan (2010)

\section{PUBLICATIONS}

- Maiden, Emily, "Transformative Peace in the Democratic Republic of the Congo" in the Journal of International Peacekeeping (forthcoming).

\section{CONFERENCE PRESENTATIONS}

- "Girls with Guns: The Disarmament and Demobilization of Female Ex-Combatants in Africa." To be presented at the International Conference on Transitional Justice in Post-Conflict Societies, Hekima Institute of Peace Studies and International Relations, Nairobi, Kenya (October 2014)

- "But He's Not My Husband: The Disarmament and Demobilization of Female ExCombatants in Africa." Presented at the Graduate Research Symposium, University of Louisville, Louisville, Kentucky. Won Best Presentation and $\$ 100$ prize (April 2014)

- "No War, No Peace: Transforming the Peace Process in the DRC." Presented at the Notre Dame Student Peace Conference, University of Notre Dame, South Bend, Indiana (March 2014)

- "Transformative Peace in the Democratic Republic of the Congo." Presented at the Kentucky Political Science Association, Morehead State University, Morehead, Kentucky (March 2014)

- "Transformative Peace in the Democratic Republic of the Congo." Presented at the Southern Political Science Association (SPSA), New Orleans, Louisiana (2014)

- "Principled Negotiation in Practice: An Exploration of the Minerva Reef Territorial Dispute between Tonga and Fiji." Presented at the Indiana Political Science Association, Indiana Southern University, Evansville, Indiana (March 2013) 
- "The Unwelcome Mat: An Exploration of the Development of International Refugee Law and the 'Refugee Problem' in Contemporary Japan." Presented at the Southern Regional Honors Conference, Little Rock, Arkansas (March 2011)

- "The Unwelcome Mat: Exploring the 'Refugee Problem' in Japan." Presented at the Kentucky Honors Roundtable, Kentucky State University, Frankfort, Kentucky (February 2011)

- "Reality Control in George Orwell's 'Nineteen Eighty-Four' Examined through the Hegelian Master-Servant Dialectic." Presented at the Midsouth Philosophy Conference, University of Memphis, Memphis, Tennessee (March 2011)

\section{PAPER AWARDS \& RECOGNITION}

- Social Justice Research Paper Award (\$300); granted by the Anne Braden Institute for Social Justice Research for "Inventing a New Peace in the Democratic Republic of the Congo: Learning from the Failures of the 1999 Lusaka Ceasefire Agreement" (2013)

- Best Thesis in the Social Sciences for "The Unwelcome Mat: An Exploration of the Development of International Refugee Law and the 'Refugee Problem' in Contemporary Japan" (2011)

\section{HONORS, SCHOLARSHIPS, GRANTS}

- Graduate Dean's Citation, School of Interdisciplinary and Graduate Studies, University of Louisville (2014)

- Graduate Student Travel Grant $(\$ 1,000)$, Political Science Dept., University of Louisville (2014)

- Prestage-Cook Travel Award (\$250), Southern Political Science Association (2014)

- Graduate Travel Grant (\$350), College of Arts \& Sciences Graduate Student Council (2014)

- Louis Kesselman Award $(\$ 3,500)$; departmental award granted to the top three students in the Political Science Department (2011)

- Book Prize Award; departmental award granted to the top two graduating seniors in Philosophy. Students receive a generous collection of academic works (2011)

- IIE-NSEP David L. Boren Scholarship to Japan $(\$ 20,000)$; provides American undergraduates with skills and experience in areas of the world deemed critical to U.S. national security in exchange for one year of service in the federal government (2009-2010)

- Kentucky Colonel, highest civilian honor in the state of Kentucky (2009)

- Bridging Scholarship $(\$ 4,000)$; provided by the American Association of Teachers of Japanese to American undergraduate students for study in Japan (2009-2010)

- UofL Honors Scholar; an elective program within the University Honors Program dedicated to fostering interdisciplinary studies through advanced seminars, including seminars with an international travel component. In 2009 completed international travel seminar to India (2007-2011)

- Kentucky Educational Excellence Scholarship (KEES); room and board (2007-2011)

- Trustees Full Tuition Scholarship (2007-2011) 


\section{WORK \& INTERNSHIP EXPERIENCE}

- Assistant to the Director, Office of National and International Scholarship Opportunities, University of Louisville, Louisville, KY (August 2012-present)

- Transportation Security Officer, Department of Homeland Security, Louisville, KY (February 2012-August 2012) fulfilled Boren service requirement

- Server, Miyoshi Japanese Restaurant, Florence, KY (June 2011-February 2012)

- Intern, Office of Congressman Geoff Davis, Ft. Mitchell, KY (May 2009-August 2009)

- Cardinal Host Student Assistant, University of Louisville Office of the President, Louisville, KY (August 2008-May 2011)

\section{WORKSHOPS \& PROFESSIONAL DEVELOPMENT}

- Graduate Teaching Academy, UofL Delphi Center for Teaching and Learning and the School of Interdisciplinary and Graduate Studies (2013-2014)

A year-long series of sessions designed to promote knowledge, skills, and excellence in college teaching. Participation is limited and competitive.

\section{EXTRACURRICULAR \& CIVIC INVOLVEMENT}

- Kentucky Political Science Association (KPSA), member (2014- )

- Grant Selection Committee Member, College of Arts \& Sciences Graduate Student Union (2014)

- Southern Political Science Association (SPSA), member (2013- )

- Vice President, College of Arts \& Sciences Graduate Student Union (2013- )

- Political Science Representative, College of Arts \& Sciences Graduate Student Union (2013-)

- Foreign Affairs Campus Coordinator, U.S. Department of State (2012- )

- Peer Advisor, University of Louisville International Center (2010-2011)

- Phi Sigma Tau, National Philosophy Honors Society (2009-2011); Treasurer (20082009)

- American Delegate, $61^{\text {st }}$ Japan-America Student Conference (JASC) (Fall 2009)

- Kentucky Congressional Leadership Program, Office of Congressman Geoff Davis (Summer 2009)

- Pi Sigma Alpha, National Political Science Honors Society (2008-2011)

- Honors Student Council, University of Louisville Honors Program (2007-2011); Freshman Executive (2007-2008); Historian (2010-2011)

- Japan Club, University of Louisville (2007-2009); Co-founder (2007); Vice President (2007-2008); President (2008-2009)

- Honors Volunteer Program, University of Louisville Honors Program (2007-2011) 